REPORT \# ESD/LM/00-2

PUB NO. T/560

\title{
MARKET ASSESSMENT OF THE
}

NATIVE PLANT INDUSTRY

IN WESTERN CANADA 
Digitized by the Internet Archive in 2016

https://archive.org/details/marketassessment00woos 


\title{
Market Assessment of the Native Plant Industry in Western Canada
}

\author{
Jay Woosaree \\ Alberta Research Council
}




\section{Pub. No: T/560}

\section{ISBN: 0-7785-1384-X Printed Edition}

\section{ISBN: 0-7785-1385-8 On-line Edition}

Web Site: http://www.gov.ab.ca/env/protenf/landrec/index.html

Although prepared with funding from Alberta Environment (AENV), the contents of this report/document do not necessarily reflect the views or policies of $A E N V$, nor does mention of trade names or commercial products constitute endorsement or recommendation for use.

Any questions on this document may be directed to:

Environmental Sciences Division

Alberta Environment

$4^{\text {th }}$ Floor, Oxbridge Place

$9820-106^{\text {th }}$ Street

Edmonton, Alberta T5K 2J6

Phone: (780) 427-5883

Fax: (780) 422-4192

Email: land.management@gov.ab.ca

Additional copies of this document may be obtained by contacting:

Information Centre

Alberta Environment

Main Floor, Great West Life Building

$9920-108^{\text {th }}$ Street

Edmonton, Alberta T5K 2M4

Phone: (780) 944-0313

Fax: (780) 427-4407

Email: env.infocent@gov.ab.ca

This publication may be cited as:

Woosaree, J., 2000. Market Assessment of the Native Plant Industry in Western Canada.

Prepared for Alberta Environment and Alberta Agriculture, Food and Rural Development by Alberta Research Council, Vegreville, Alberta. Report \# ESD/LM/00-2. ISBN: 0-7785-1384-X, Publication No: T/560. $106 \mathrm{pp}$. 


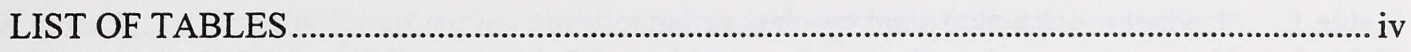

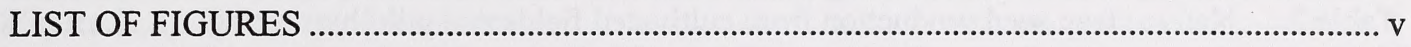

Acknowledgements........................................................................................................... vi

Executive Summary .............................................................................................................. vii

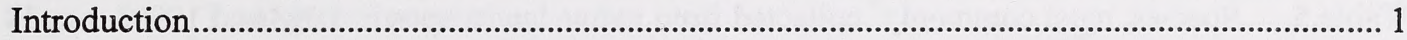

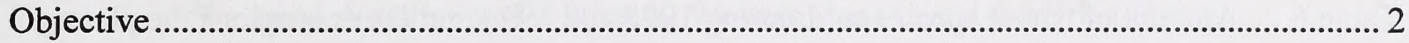

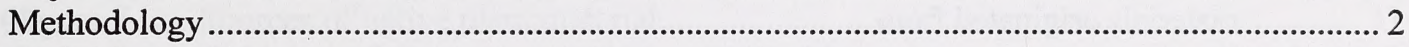

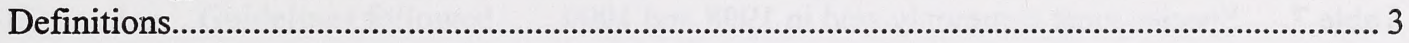

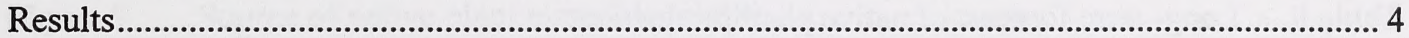

Native Plant Producers Survey ............................................................................................. 5

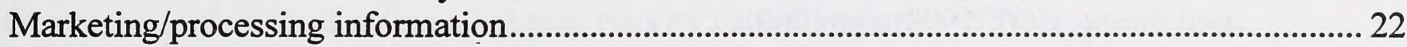

Native Plant User Survey ......................................................................................................... 33

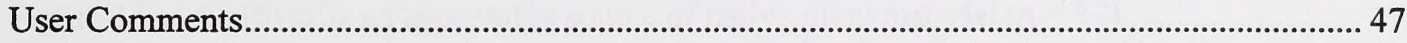

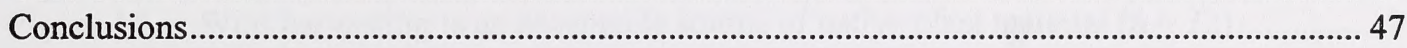

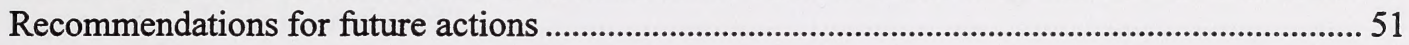

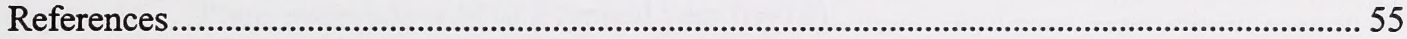

APPENDIX 1 - Species harvested in the wild, by amounts and by ecoregion............................... 56

APPENDIX 2 - Amount and origin of plant materials sold in 1998 and 1999.............................65

APPENDIX 3 - Longterm forecast of native plant production....................................................... 71

APPENDIX 4 - Amount spent on native species, projected use and ecoregions of

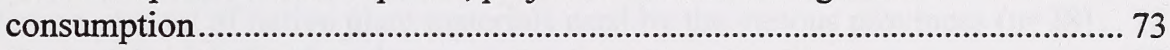

APPENDIX 5 - Native Plant Market Assessment - Producer/Supplier Survey............................ 75

APPENDIX 6 - Native Plant Market Assessment - User Survey ..................................................... 84

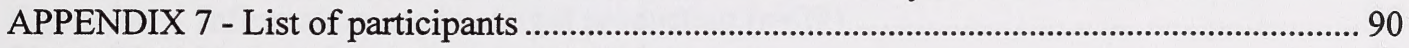

APPENDIX 8 - Ecological Regions of North America.................................................................. 105

APPENDIX 9 - Natural Regions ……………………............................................................... 106 


\section{LIST OF TABLES}

PAGE

Table 1. Production of native plant species ............................................................................. 8

Table 2. Native clean seed production from cultivated fields and wild harvesting..................... 8

Table 3. Revenue distribution for Alberta, Western Canada and the Great Plains..................... 10

Table 4. Amount of plant materials harvested from native landscapes in each ecoregion ........ 13

Table 5. Species, most commonly ${ }^{*}$ collected from native landscapes in 1998 and 1999......... 14

Table 6. Amount of native species sold during 1998 and 1999 and the ecoregions the plant materials originated from ......................................................................................... 20

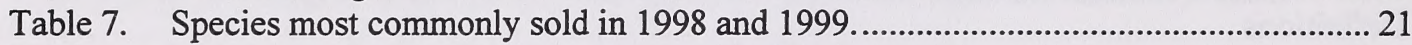

Table 8. Long- term forecast of native plant production. ......................................................... 31

Table 9. Amount of native species purchased and the ecoregion the plant materials were used during 1997, 1998, and 1999.

Table 10. Projected use and ecoregion of native plant material in 2000 and 2001.................... 46 


\section{LIST OF FIGURES}

PAGE

Figure 1. Distribution of survey questionnaires and number of responses received.................. 4

Figure 2. Category of responses ........................................................................................ 5

Figure 3. Time allocated to native plant business ....................................................................... 6

Figure 4. Years in the native plant business ............................................................................ 7

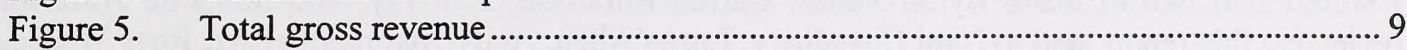

Figure 6. Revenue distribution for Alberta, Western Canada and the Great Plains................. 10

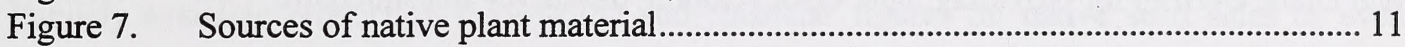

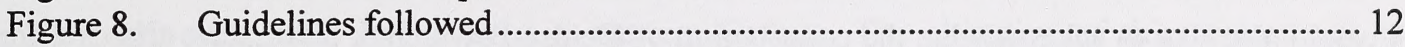

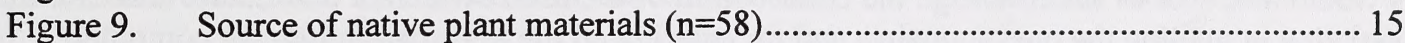

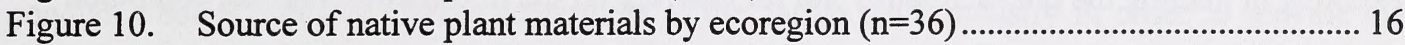

Figure 11. Source of native plant materials by natural region $(\mathrm{n}=55)$...................................... 17

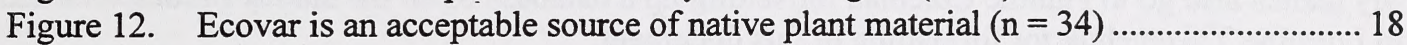

Figure 13. Cultivar is an acceptable source of native plant material $(n=33)$........................... 19

Figure 14. Wild harvesting is an acceptable source of native plant material $(n=32) \ldots \ldots \ldots \ldots . . . .19$

Figure 15. How is seed sold?................................................................................................. 22

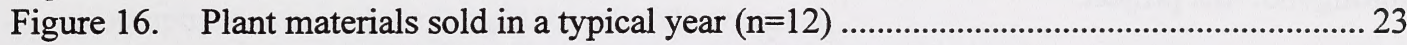

Figure 17. Information provided to users of native plants $n=39 \ldots \ldots \ldots \ldots \ldots \ldots \ldots \ldots \ldots \ldots \ldots \ldots \ldots \ldots \ldots . . . .24$

Figure 18. Distances plant materials sold from main point of business $(n=33) \ldots \ldots \ldots \ldots \ldots \ldots \ldots \ldots . . .25$

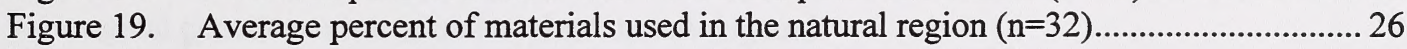

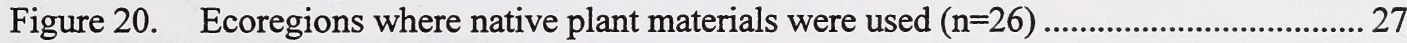

Figure 21. Average percent of native plant materials used by the various provinces $(n=38) \ldots 28$

Figure 22. Marketing means of native plants ............................................................................ 29

Figure 23. Average percent of native plant materials used by various industries $(n=33) \ldots \ldots . . .30$

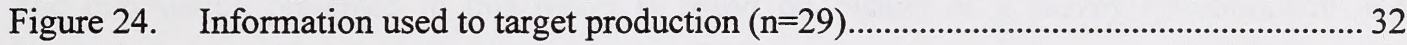

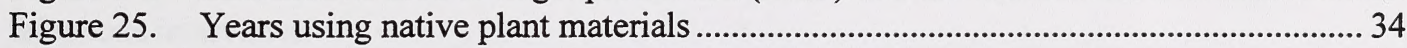

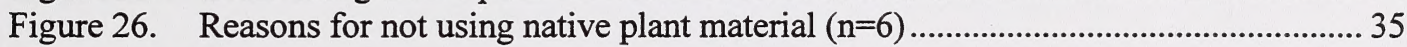

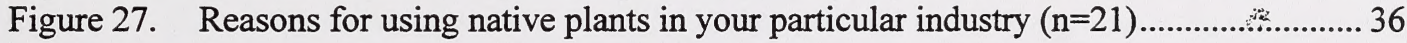

Figure 28. Ecovar is an acceptable source of native plant material $(n=20)$.................................3 37

Figure 29. Cultivar is an acceptable source of native plant material $(n=19)$.............................. 38

Figure 30. Wild harvesting is an acceptable source of native plant material $(\mathrm{n}=19) \ldots \ldots \ldots \ldots . . . . . .38$

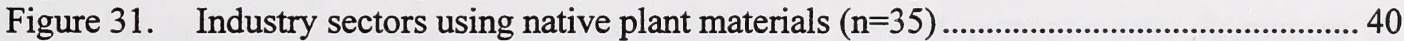

Figure 32. Distance between business place and the grower/supplier $(n=14) \ldots \ldots \ldots \ldots \ldots \ldots \ldots \ldots . . . .41$

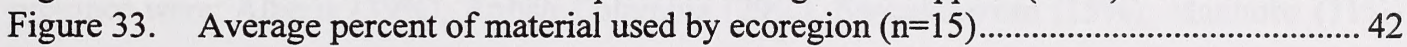

Figure 34. Average percent of material used by geographical area $(n=15)$.............................. 43

Figure 35. Knowledge of original genetic source of the plant material purchased $(n=19)$....... 44

Figure 36. Information provided regarding native plant material purchased $(\mathrm{n}=20) \ldots \ldots \ldots \ldots \ldots . . . .45$

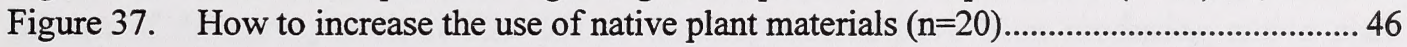




\section{Acknowledgements}

I am grateful to Alberta Environment for providing funding of this study. I would like to thank members of the Reclamation and Remediation Research Users Group for approving funding of this study.

I would also like to thank Byron James, Darren Robinson, Ken Fry, and Michelle Hiltz for reviewing this report, and to Nabi Chaudhary, Lorna Allen, Andy Hammermeister, Ross Wadell, and Diane Gertzen for providing input on developing the survey questionnaire.

I would also like to acknowledge the contribution of Denise Pewarchuk and Laurie Checkel for assisting in mailing the questionnaires and for entering all the information into the computer.

My thanks also go to Pauline Coleman for setting up a database of all the survey participants and to Lorraine Yakemchuk for formatting of this document.

At last, I am grateful for the support I received from Heather Gerling and Chris Powter throughout this project. 


\section{Executive Summary}

The native plant industry in Alberta has been in existence for approximately thirty years. Over time, interest in the use of native plants has been growing steadily. Many consumer magazines and newspaper articles have coined the native plant industry as a "fledgling market" or a "burgeoning industry".

Publicly available production information and financial figures on native seed sales or even reclamation seed sales do not exist in western Canada. The objective of this project was to conduct a comprehensive market assessment of the native plant industry in order to provide the following information:

- seed sources,

- current market demand and future production of native plant materials,

- geographical areas where the plant materials are used,

- market value of the industry,

- original genetic source of native plant materials., and.

- obstacles affecting the industry.

The information presented in this report is based on results of a survey questionnaire and telephone interviews.

Two hundred and forty three survey questionnaires were mailed to a list of producers and suppliers of native plant materials as identified by the native plant councils of Alberta, British Columbia and Saskatchewan. There was a forty five percent response rate. Responses by province were: Alberta (39\%), British Columbia (29\%), Saskatchewan (15\%), Manitoba (11\%) and other provinces and the United States (6\%).

Results of the survey indicate that $6 \%$ of the respondents have been producing native plant materials for more than 25 years. The industry has been growing steadily with $36 \%$ of the respondents producing native plants in the last 10 to 25 years followed by another $58 \%$ joining the industry in the last decade. About half of the respondents spent less than $20 \%$ of their time in 
the native plant business and only $23 \%$ of the respondents work in the native plant industry on a full-time basis. Most commonly reported income range in 1998 was $\$ 25,000$ or less and the total gross income $(n=38)$ during that year was $\$ 7.03$ million. There is no significant relationship between amount of time spent in the native plant business, years producing native plant materials and gross revenue. In reality the native plant industry is worth more than $\$ 7.03$ million since many producers did not provide revenue information. Revenue distribution for Alberta, Western Canada and the Great Plains are $\$ 1.33$ million, $\$ 4.85$ million and $\$ 5.08$ million respectively.

Over 250 species of various plants were collected from native landscapes. The amount of material collected for a particular species ranged from $10 \mathrm{~g}$ to $50 \mathrm{~kg}$ of seeds and from 10 plants to 10,000 plants. In $1998,726 \mathrm{~kg}$ of seeds and 14,481 plants were collected from native landscapes.

In 1999 , the amount of seed collected went down by $65 \%$ and the number of plants collected increased by over $80 \%$. A number of respondents indicated that they collected seeds and plants from native prairies but did not indicate the amount of plant material collected. Over $50 \%$ of the collecting activity occurred in the Great Plains ecoregion.

Thirty two percent of the seed source originates from Alberta, 24\% from British Columbia, $12 \%$ from Saskatchewan, 10\% from Manitoba, 19\% from the United States and about 3\% from other places. When producers were asked which ecoregions they source their native plant materials from, the majority of them (37\%) checked the Great Plains. When the same question was asked about the natural region, $63 \%$ of the respondents obtained their plant materials within the Grassland, Parkland and Foothills natural region.

Approximately 57 species of grasses, 14 wetland species, 103 forbs species and 73 species of woody plants were produced in 1998 and 1999. In 1998, 299,450 kg of grass seeds and 13,930 plants were produced. Seed production increased up to $387,425 \mathrm{~kg}$ while the number of plants produced decreased to 9,950 in 1999. Forb production was 22,137 plants in 1998 and increased to 42,678 in 1999 . Similarly, production of wetland plants went up by $33 \%$ to 2,700 plants and production of woody plants decreased by $13 \%$ to 717,020 plants. In total, the amount of native 
seed produced went up by $23 \%$ to $394,160 \mathrm{~kg}$ and the number of plants went down by $11 \%$ to 772,348 plants.

Most of the plant materials sold were used in the Grassland region (26\%), followed by Parklands and Foothills with $12 \%$ and $8 \%$ respectively. The producers indicated that $46 \%$ of plant material was sold in the Great Plains. British Columbia and Alberta accounted for $56 \%$ of the native plant materials used. Nineteen percent of the plant materials were used in Saskatchewan and Manitoba. About $9 \%$ of plant materials were sold to Minnesota, North Dakota, Washington and Oregon.

Producers indicate that they sold native plant materials to various industries. These included agriculture (9\%), horticulture (19\%), landscaping (18\%), wildlife habitat mitigation (15\%), wetland restoration (9\%), medicinal uses $(1 \%)$, and reclamation (29\%). The reclamation sector was further divided into oil \& gas (11\%), sand \& gravel (5\%), railways \& roadways (7\%), and mines $(6 \%)$.

Of the users surveyed $(n=22), 36 \%$ indicated they had been using native species in their operation for 10 to 25 years. Among the reasons for using native plants, $21 \%$ of the respondents indicated that native plants performed better than introduced species, $24 \%$ indicated changing regulations and another $24 \%$ said to increase biodiversity. Other reasons included, aesthetic value, conservation of the natural ecosystem or less invasive when compared to forage species. Thirty seven percent of respondents indicated they do not use native species for a number of reasons, including cost of native seed, lack of available of species, lack of quality, lack of information and have not been requested by government regulatory agencies.

Most of the plant material purchased was used in the Great Plains (55\%). The majority of respondents showed no preference for type of plant material, whether a cultivar, ecovar or wild harvested seeds.

Sixty nine percent of the respondents were aware of the original genetic source of materials purchased. Thirty one percent did not have any information of the original genetic source of their 
plant material. Three quarters of the respondents received information such as seed germination, purity, and source of seed from the producer.

Among the users of native plants, the horticulture industry represents $20 \%$, landscaping $17 \%$, wildlife habitat mitigation $9 \%$, wetland restoration $9 \%$, medicinal $6 \%$, landfills $3 \%$, agriculture $6 \%$, prairie restoration $6 \%$ and reclamation $24 \%$. The reclamation is further divided into oil \& gas (14\%), sand \& gravel (2\%), railways \& roadways (2\%), and mines (6\%). 


\section{Introduction}

The native plant industry in Alberta has been in existence for approximately thirty years. Early interest was mainly directed to using native plants in reclamation. Over the last decade there has been a change in public attitude towards the use of native species. This interest is mainly due to increased public awareness about the need to protect the natural environment and also the change in land management policies by public agencies. In the past 10 years, Public Lands Division of Alberta Agriculture, Food and Rural Development (AAFRD), the Land and Forest Service of Alberta Environment (AENV) and the Special Areas Administration of Alberta (Municipal Affairs) have recommended the use of native plants for the rehabilitation of disturbances on public lands in Alberta.

Lately, many consumer magazines and newspaper articles have described the native plant industry as a "fledgling market", "cottage industry" or "burgeoning industry". The surge in interest has resulted in new entrepreneurs joining the industry. This has also led to increased demand for information on growing and marketing of native plants.

In the past few years, a number of pioneering efforts stemming from AAFRD, AENV and Alberta Research Council (ARC) have taken place. These include:

- An international workshop on native plant production (Native Plant Summit IV);

- Annual workshops on growing and marketing of native plants, held at Alberta Research Council, Vegreville;

- The publication on Growing Native Plants of Western Canada and the Guide to Using Native Plants on Disturbed Lands, both of which are published and available through AAFRD;

- Release of videos entitled Restoring our Prairie Heritage and Reclaiming Native Prairie available through AAFRD.

Until now there have been no government agricultural statistics reporting on the annual output or value of the native seed industry in western Canada. The exception being Saskatchewan, where a market assessment was done in 1997.

This study differs from the Saskatchewan survey in that it looks at the geographical distribution of native plant material, genetic origin of the native plant material and identifies the sectors and 
geographical areas where native plant material is used. This survey provides comprehensive information about production and future demand for native plants and the quantity of plant material currently in production and use.

\section{Objective}

The objective of this project was to complete a market assessment of the native plant industry in the western Canadian provinces by collecting the following information:

- seed sources,

- current market demand and future production of native plant materials,

- the geographical areas where the plant material is used,

- the market value of the industry,

- species in demand,

- the original genetic source of native plant material, and

- obstacles affecting the industry.

\section{Methodology}

The information provided in this report is based on the data collected in the survey and telephone interviews. The survey questionnaire was developed in consultation with the native plant councils of Alberta (ANPC), Saskatchewan (SNPC) and British Columbia (BCNPC). Both BCNPC and SNPC were interested in conducting a similar survey and this approach will eliminate duplication. It was hoped that the producers and suppliers of native plant material would identify the various sectors using native plant material. The survey was mailed to seed growers and suppliers of native plant material identified on lists provided by ANPC, BCNPC and

SNPC and selected producers identified by the Canadian Seed Trades Association. A user survey was also developed and randomly sent to some users of native plant material in Alberta in order to collect additional information from a user's point of view. A total of 243 questionnaires were mailed out. Telephone interviews were conducted and e-mail enquiries were sent out to addresses where questionnaires were not returned. 


\section{Cultivated native}

Cultivar

Ecovar

Forb

Genetic origin

Legume

Native landscape

Native plant

Native plant material

Producer

Shrub

Supplier

Wild harvest

\section{Definitions}

Species originally collected from the wild and grown for production.

A named variety, which has been produced by artificial selection techniques for better performance.

An ecological variety (coined by Ducks Unlimited) of a native plant species artificially selected to produce a population containing maximum genetic variability.

Broad-leaved flowering plant with net-like veins.

The place where the plant material was first collected.

Any plant in the Leguminosae family. The fruit consists of a dry pod (e.g., peas).

A view on land that contains indigenous plants and plant communities that have not been substantially altered by man.

Any species of plant that existed in western Canada, prior to European settlement.

Any plant parts used for propagation such as seed, cuttings, rootstocks and bulbs.

A person or business that grows native plant material to be used or consumed by others

A woody plant, mostly less than $5 \mathrm{~m}$ tall and usually with several stems.

A person or business that makes native plant material available to the users.

Plant material taken directly from the natural habitat. 


\section{Results $(n=109)$}

\section{Figure 1. Distribution of survey questionnaires and number of responses received}

Surveys received

Q Surveys sent out

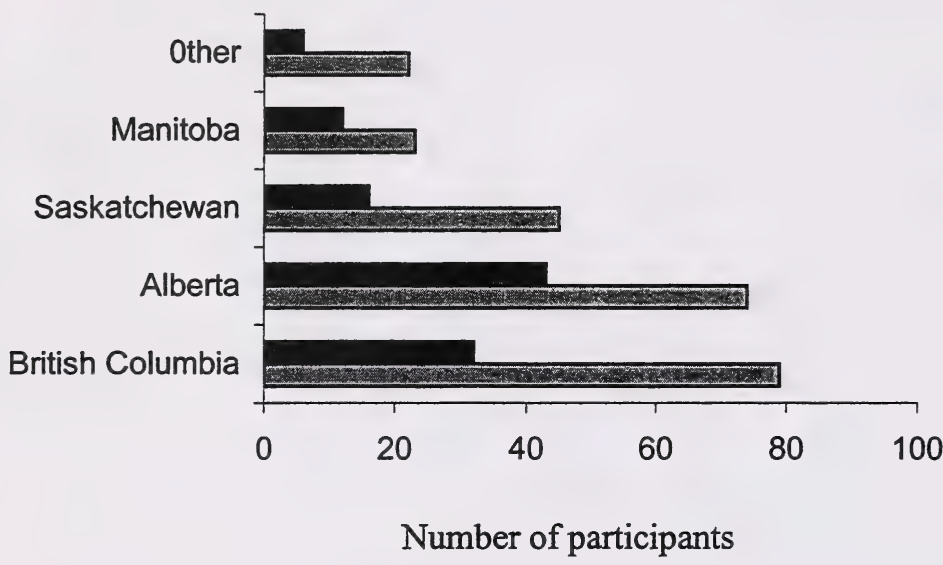

Two hundred and forty three surveys were mailed out. One hundred and nine responses were received, representing a $45 \%$ response.

"Other" includes responses from the United States and other provinces. The producer survey was sent to the United States and other provinces because some plant materials are purchased from outside the western provinces.

This page to replace page 4 of the publication titled "Market assessment of the native plant industry in western Canada".

Report \# ESD/LM/00-2, Pub no. T/560 


\section{A. Native Plant Producers Survey}

$$
(\mathrm{n}=55 \text { total })
$$

1. Please indicate whether you are a producer, supplier or both of native plant materials.

\section{Figure 2. Category of responses}

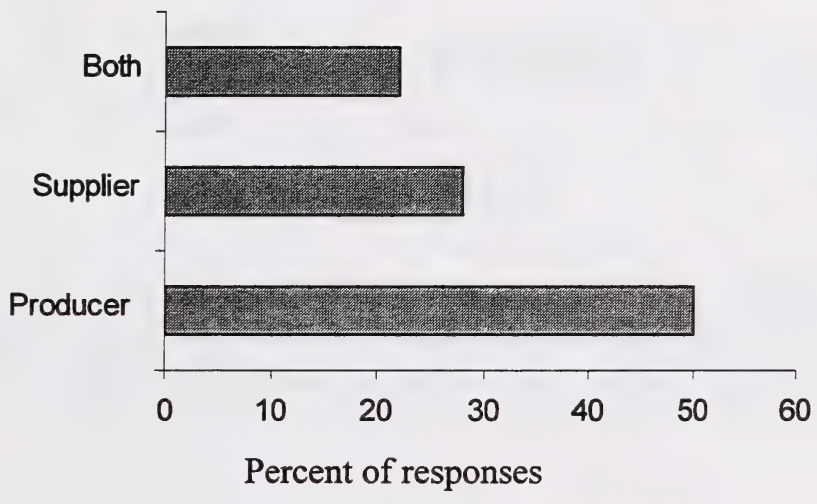

Fifty percent of the respondents were producers. Twenty eight percent of the respondents are suppliers and $22 \%$ of the respondents were both suppliers and producers of native plant material. 
2. During the last year, how much of your work time is devoted to the native plant business?

Figure 3. Time allocated to native plant business

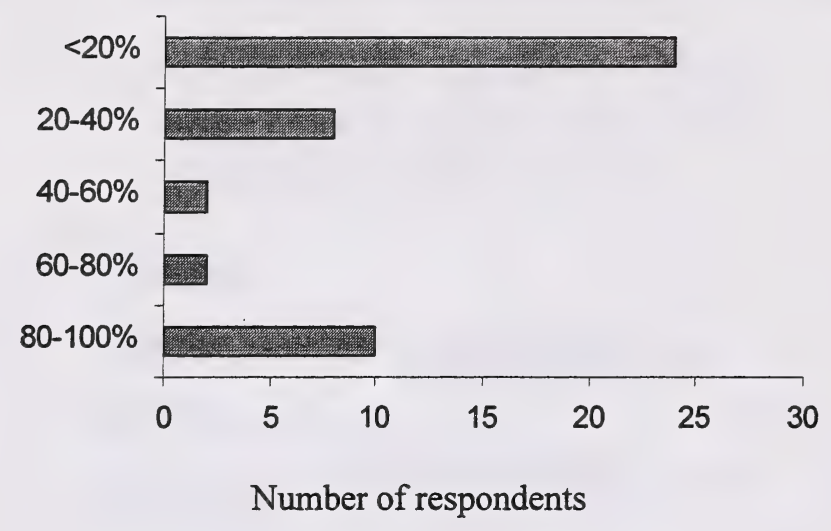

Twentyfour respondents devote less than $20 \%$ of their time to running their native plant business. Eight respondents spent $20 \%$ to $40 \%$ of the time running their business. Four respondents spent $40 \%$ to $60 \%$ and another 4 respondents spent $60 \%$ to $80 \%$ of the time in their native plant business. Ten respondents work full time in their native plant business. 
3. How many years have you been in the native plant business?

Figure 4. Years in the native plant business

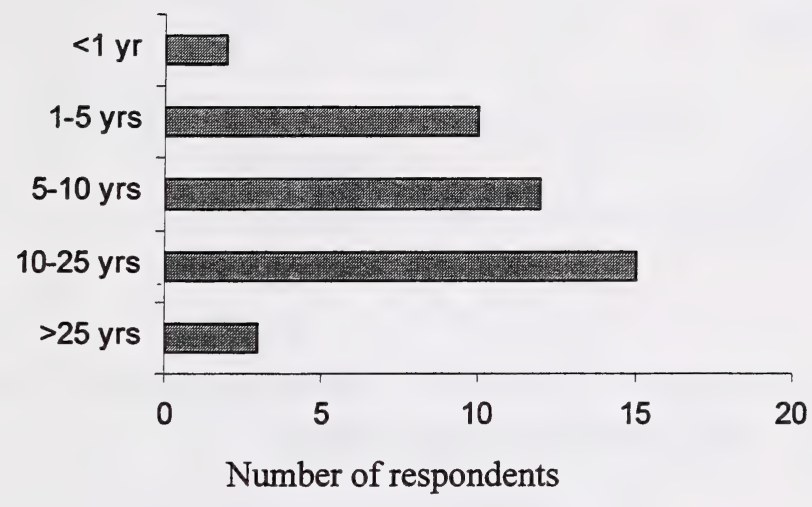

Fifteen respondents have been in the business for 10 years or more. Twelve respondents have been in the business for 5 to 10 years and 10 respondents have been in business for 1 to 5 years. Two respondents have recently started growing native plants and 3 respondents have been in business for more than 25 years. 
4. In 1998, how many acres / \# of plants did you have in production? Greenhouse operators, if plants are propagated, please use number of plants.

Table 1. Production of native plant species

\begin{tabular}{|l|r|r|r|r|c|}
\hline & Grasses & \multicolumn{1}{|c|}{ Forbs } & Legumes & Shrubs & Wetland species \\
\hline Total number of acres & 2,300 & 19 & 28 & 160 & 61 \\
\hline Number of respondents & 10 & 10 & 8 & 11 & 5 \\
\hline & & & & & \\
\hline Total number of plants & 73,050 & 160,900 & 52,400 & $1,571,900$ & 61,150 \\
\hline Number of respondents & 8 & 9 & 5 & 11 & 4 \\
\hline
\end{tabular}

Note. The legumes are not part of the forb component.

5. In 1998, what is your total native clean seed production $(\mathrm{kg})$ from cultivation and wild harvesting?

Table 2. Native clean seed production from cultivated fields and wild harvesting.

\begin{tabular}{|l|c|c|}
\hline & Cultivation $(\mathrm{kg})$ & Wild harvest $(\mathrm{kg})$ \\
\hline & & $\begin{array}{c}726 \\
(\mathrm{n}=13)\end{array}$ \\
\hline Total seeds & $\begin{array}{c}181,579 \\
(\mathrm{n}=17)\end{array}$ & 55.8 \\
\hline $\begin{array}{l}\text { Average amount of seed } \\
\text { per producer }\end{array}$ & 10,681 & \\
\hline
\end{tabular}


6. In 1998 , what was your total gross revenue (\$) from sales of native plant material?

Figure 5. Total gross revenue

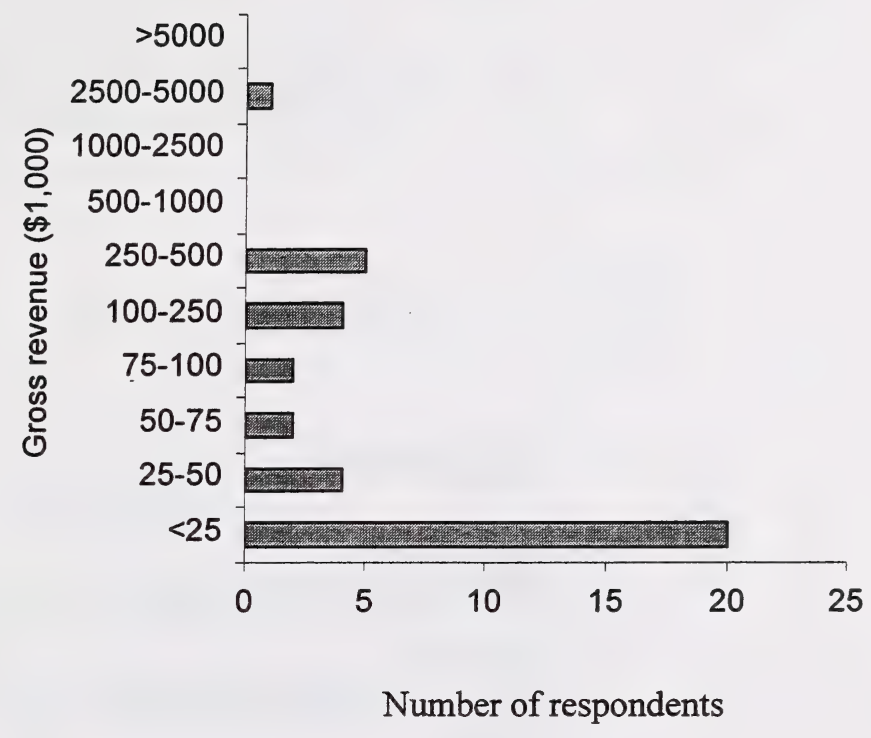

More than half (Mode) of the respondents $(n=38)$ had gross income of less than $\$ 25,000$ in 1998. Fourteen respondents reported income of more than the $\$ 100,000$ range with one producer reported income of more than $\$ 2.5$ annually.

The total worth of the industry based on the number of responses received was $\$ 7.03$ million. The average gross income per producer was $\$ 184,868$ in 1998 while median income reported was $\$ 25,000$ or less. The species most commonly sold included shrubs and trees for landscaping and horticulture and grasses for reclamation. 
Figure 6. Revenue distribution for Alberta, Western Canada and the Great Plains

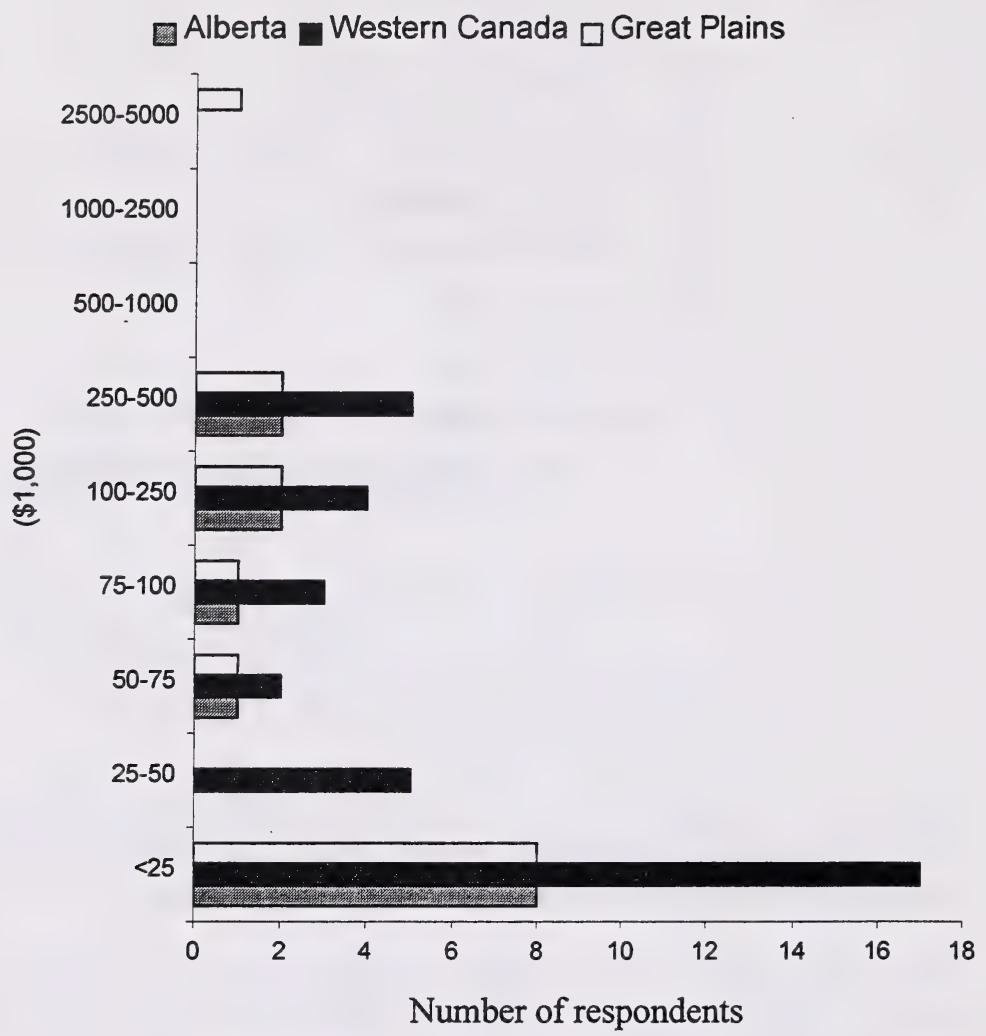

Most commonly reported income range is less than $\$ 25,000$.

Table 3. Revenue distribution for Alberta, Western Canada and the Great Plains

\begin{tabular}{c|ccc}
\hline & Alberta & Western Canada & Great Plains \\
\hline Total Income $(\$)$ & $1,330,000$ & $4,850,000$ & $5,080,000$ \\
& $(\mathrm{n}=14)$ & $(\mathrm{n}=36)$ & $(\mathrm{n}=15)$ \\
Average Income $(\$)$ & 95,000 & 134,722 & 338,667 \\
& & & \\
Median Income (\$) & $<25,000$ & $25,000-50,000$ & $25,000-50,000$ \\
\hline
\end{tabular}

Note. Western Canada and the Great Plains values include Alberta. 
7. From which of the following sources do you receive your native plant materials? Please check more than one if applicable.

$\square$ I collect the seed from native landscapes (wild harvest).

$\square$ I collect the seed from my own crop

$\square$ I purchase the seed from other producer.

$\square$ I purchase the seed from other supplier.

$\square$ Other (please specify)

\section{Figure 7. Sources of native plant material}

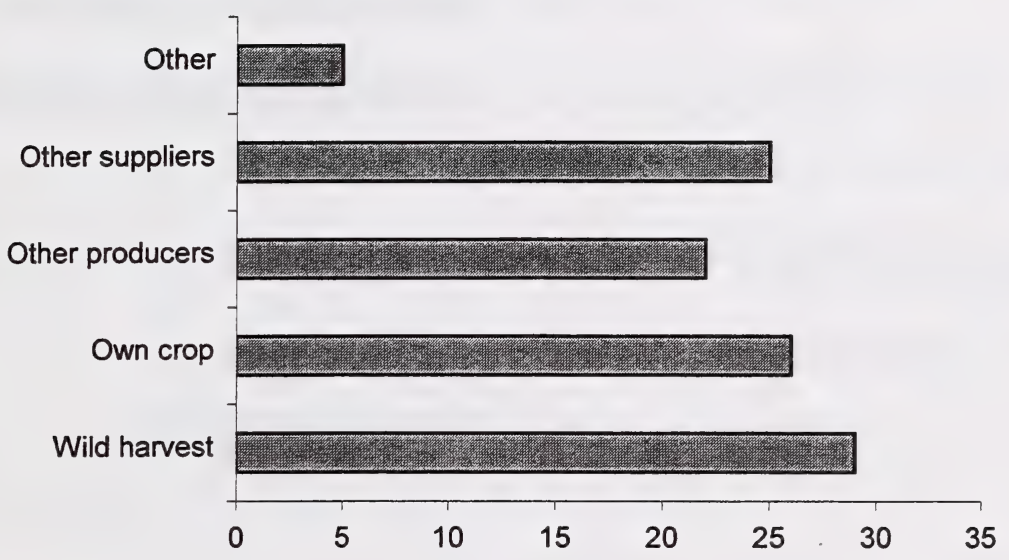

Number of respondents

Seventy eight percent of the respondents use multiple sources for their native plant material.

Other sources include:

1. Bulbs rescued from disturbed sites.

2. Ducks Unlimited.

3. Exchange with other collectors, botanists and botanical gardens.

4. Grower - collected cuttings.

5. Plugs from other suppliers.

6. Vegetative propagation from own stock. 
8. Do you follow any guidelines, for example as set up by the Alberta Native Plant Council when harvesting from native landscapes.

(a) I follow the Alberta Native Plant Council guidelines.

(b) I follow Saskatchewan Native Plant council guidelines Recommendations for the collection \& use of native plants.

(c) I follow the guidelines as set up by Public Lands, Alberta Agriculture, Food and Rural Development.

(d) I am aware of the guidelines, but do not follow them.

(e) I follow similar guidelines from my location.

(f) I was not aware of any guidelines.

Figure 8. Guidelines followed

$$
(n=41)
$$

Not aware of any guidelines

Similar guidelines from my location

Aware of the guidelines, but do not follow

Saskatchewan Native Plant Council guidelines

Guidelines set up by Public Lands, AAFRD

Alberta Native Plant Council guidelines
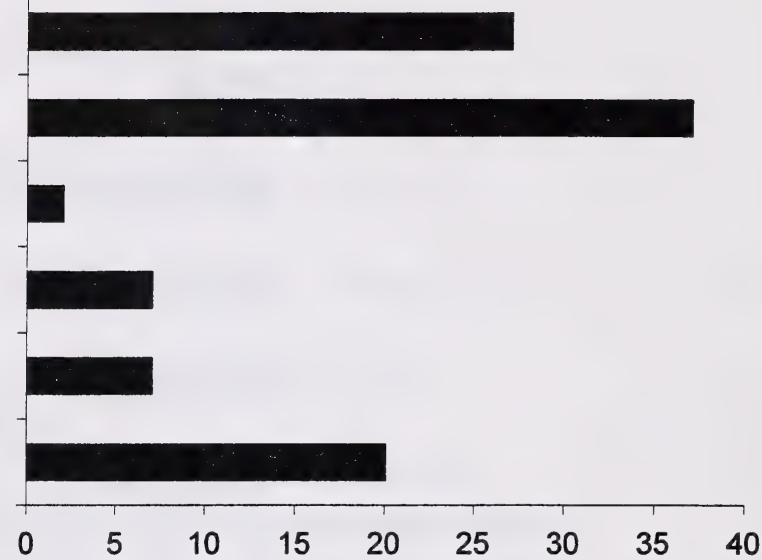

Percent of respondents

The majority of the respondents followed some kind of guidelines. $37 \%$ followed guidelines developed by their local area. Others followed the Alberta Native Plant Council guidelines (20\%) and an equal number of respondents (7\%) followed the guidelines as defined by the Saskatchewan Native Plant Council and Public Lands Division of Alberta Agriculture, Food and Rural Development. A very small number of respondents were aware of guidelines about collecting plant materials from native landscapes but chose not to follow them. It is interesting to note that a high percentage of the respondents $(27 \%)$ are not aware of any guidelines regarding wild harvesting. 
Other guidelines are:

1. British Columbia Nursery and Landscape Association.

2. Following their company guidelines.

3. Only harvest wild seed (not plants), collect less than $59 \%$ of seed from wild sources, never harvest at the same site in consecutive years and careful to limit impact on native prairie.

4. Ministry of Forests, Government of British Columbia.

5. Native Plant Society of British Columbia.

6. Society for Ecological Restoration.

7. Washington State guidelines.

9. Please fill out the following table showing the species harvested from the wild, the amount harvested and the ecoregion region it was harvested. Please refer to map for ecoregion.

Table 4. Amount of plant materials harvested from native landscapes in each ecoregion during 1998 and 1999.

\begin{tabular}{|l|c|c|c|c|c|c|c|c|c|c|c|c|c|}
\hline & \multicolumn{2}{|c|}{1998} & \multicolumn{2}{|c|}{1999} & \multicolumn{7}{c|}{ Ecoregions } \\
\hline & $\begin{array}{l}\text { Seed } \\
(\mathrm{kg})\end{array}$ & $\begin{array}{l}\text { Number } \\
\text { of plants }\end{array}$ & $\begin{array}{l}\text { Seed } \\
(\mathrm{kg})\end{array}$ & $\begin{array}{l}\text { Number } \\
\text { of } \\
\text { plants }\end{array}$ & G.P & Tun & Taig & A.cord & NADst & NWFMt. & N.for & Other & Unk. \\
\hline Grasses & $\begin{array}{c}1.98 \\
(\mathrm{n}=8)\end{array}$ & 0 & $\begin{array}{c}3.8 \\
(\mathrm{n}=10)\end{array}$ & $\begin{array}{c}4000 \\
(\mathrm{n}=3)\end{array}$ & 21 & 0 & 0 & 0 & 0 & 9 & 2 & 0 & 0 \\
\hline & & & & & & & & & & & & & \\
\hline Forbs & $\begin{array}{c}18.53 \\
(\mathrm{n}=40)\end{array}$ & $\begin{array}{c}2970 \\
(\mathrm{n}=4)\end{array}$ & $\begin{array}{c}112 \\
(\mathrm{n}=31)\end{array}$ & $\begin{array}{c}5650 \\
(\mathrm{n}=3)\end{array}$ & 71 & 0 & 0 & 0 & 0 & 9 & 11 & 9 & 0 \\
\hline & & & & & & & & & & & & & \\
\hline $\begin{array}{l}\text { Woody } \\
\text { Plants }\end{array}$ & $\begin{array}{c}92 \\
(\mathrm{n}=33)\end{array}$ & $\begin{array}{c}10000 \\
(\mathrm{n}=1)\end{array}$ & $\begin{array}{c}86 \\
(\mathrm{n}=36)\end{array}$ & $\begin{array}{c}10000 \\
(\mathrm{n}=1)\end{array}$ & 49 & 0 & 0 & 0 & 0 & 37 & 0 & 31 & 0 \\
\hline $\begin{array}{l}\text { Wetland } \\
\text { Plants }\end{array}$ & $\begin{array}{c}5.9 \\
(\mathrm{n}=4)\end{array}$ & $\begin{array}{c}1511 \\
(\mathrm{n}=12)\end{array}$ & $\begin{array}{c}59 \\
(\mathrm{n}=1)\end{array}$ & $\begin{array}{c}6700 \\
(\mathrm{n}=5)\end{array}$ & 38 & 0 & 0 & 0 & 0 & 8 & 17 & 2 & 0 \\
\hline & & & & & & & & & & & & & 0 \\
\hline Total & 118.41 & 14,481 & 261 & 26,350 & 179 & 0 & 0 & 0 & 0 & 63 & 30 & 42 & 0 \\
\hline
\end{tabular}

Note. $\mathrm{N}$ equals the number of responses received. The number in the ecoregion columns shows the number of responses received for each category. Each respondent collects several species from each ecoregion. A number of respondents collected seeds and plants but did not record the amount and the ecoregion from which it was harvested. Details are in Appendix 1.

G.P. $=$ Great Plains

Tun $=$ Tundra

Taig $=$ Taiga

A.cord $=$ Arctic Cordillera

NADst $=$ North American Deserts

NWFMt. $=$ Northwestern Forest Mountains

N.for $=$ Northern Forests 
Over 250 native species of grasses, forbs, woody plants, sedges and wetland plants were collected from native landscapes during 1998 and 1999. In 1998, a total of $118 \mathrm{~kg}$ of seed and 14,481 plants were harvested from native landscapes. In 1999, that number increased to $261 \mathrm{~kg}$ of seeds and 26,350 plants. This represents over $100 \%$ increase in both seeds and number of plants collected from wild harvesting. The value reported for $\mathbf{1 9 9 8}$ is far less than previously indicated (Question 5, seed harvested from native landscape $=726 \mathrm{~kg}$ ) as seed collectors indicated the species harvested and did not indicate the quantity of seed harvested. The majority of plants were collected from the Great Plains (179 responses), followed by North Western Forest Mountain and Northern Forest. A few entries were received from other locations.

Table 5. Species, most commonly ${ }^{*}$ collected from native landscapes in 1998 and 1999.

\begin{tabular}{|l|l|l|}
\hline & \multicolumn{1}{|c|}{1998} & \multicolumn{1}{c|}{1999} \\
\hline Grasses & $\begin{array}{l}\text { Stipa virdula } \\
\text { Stipa spartea }\end{array}$ & $\begin{array}{l}\text { Poa palustris } \\
\text { Panicum capillare } \\
\text { Calamagrostis purpurescens }\end{array}$ \\
\hline & & \\
\hline Wetland plants & $\begin{array}{l}\text { Myriophyllum exalbescens } \\
\text { Lemna minor } \\
\text { Hippuris vulgaris } \\
\text { Carex aquatilis } \\
\text { Equisetum hyemale }\end{array}$ & $\begin{array}{l}\text { Myriophyllum exalbescens } \\
\text { Lemna minor } \\
\text { Sagittaria cuneata } \\
\text { Hippuris vulgaris } \\
\text { Carex aquatilis }\end{array}$ \\
\hline Forbs & $\begin{array}{l}\text { Aster ericoides } \\
\text { Asclepias incarnata } \\
\text { Antennaria rosea }\end{array}$ & $\begin{array}{l}\text { Aster ericoides } \\
\text { Asclepias incarnata } \\
\text { Antennaria rosea }\end{array}$ \\
\hline Woody plants & $\begin{array}{l}\text { Rubus parviflorus } \\
\text { Amelanchier alnifolia } \\
\text { Acer spp. }\end{array}$ & $\begin{array}{l}\text { Rubus parviflorus } \\
\text { Amelanchier alnifolia } \\
\text { Acer spp. }\end{array}$ \\
\hline
\end{tabular}

" Based on the number of plants collected. All of the above species (except grasses) were plants collected from native landscapes. 
10. If native plant material is purchased from other producers/suppliers, from which province (state) do they originate?

Figure 9. Source of native plant materials $(\mathrm{n}=58)$

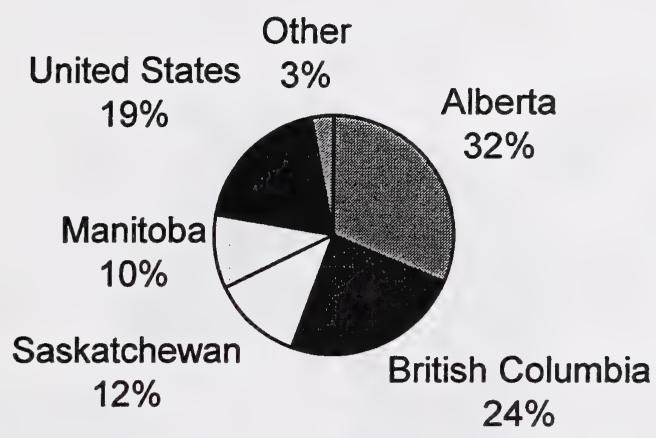

Thirty two percent of respondents received their plant materials from Alberta, followed by British Columbia with $24 \%$, Saskatchewan $12 \%$, Manitoba $10 \%$ and USA $19 \%$. One producer stated that he obtained his native plant materials from Germany. 
11. If native plant material is purchased from other producers/suppliers, from which ecoregion do they originate?

Figure 10. Source of native plant materials by ecoregion $(n=36)$

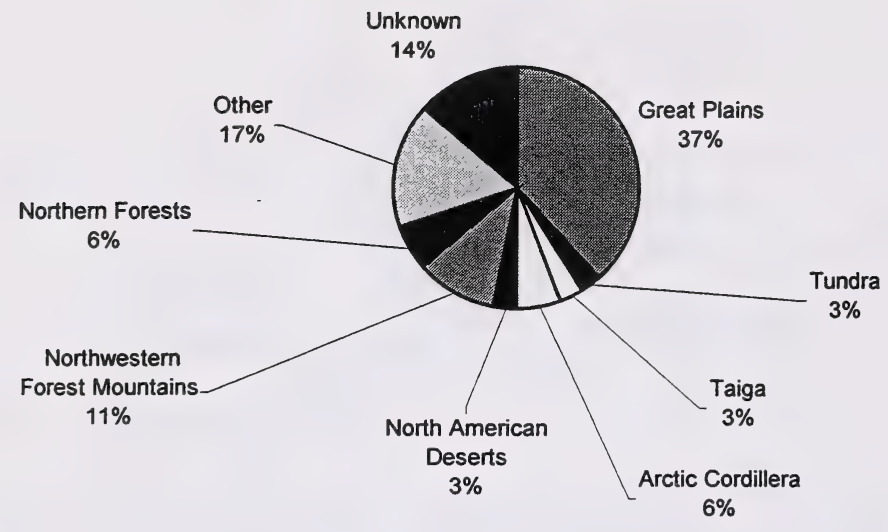

The majority of respondents (37\%) obtained their native plant materials from the Great Plains. A small percentage of the respondents obtained plant materials from other ecoregions. It is interesting to note that $14 \%$ of the respondents do not know from which ecoregion their native plant materials originated.

Ecoregions included in the "other" category are West Coast Marine Forest and temperate beaches.

Note. Different respondents answered questions 10 and 11. 
12. If native plant material is purchased from other producers/suppliers, from which Natural Region do they originate?

Figure 11. Source of native plant materials by Natural Region ( $\mathrm{n}=55)$

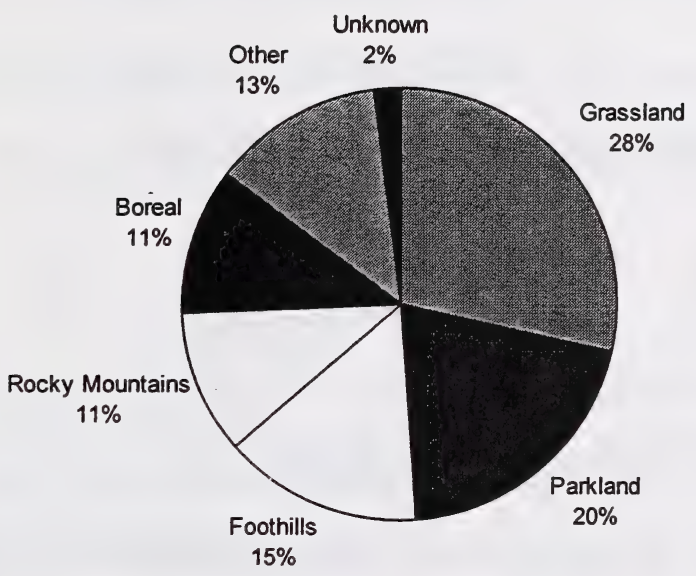

A small percentage of the respondents did not know the origin of their plant materials.

Thirteen percent of the respondents got their plant material from the West Coast Marine Forest ecoregion (Other). 
13. For each statement below, please rate on a scale of 1 to 5 ( 1 being strongly disagree, 5 strongly agree and 0 being no opinion.) your level of agreement of each statement. (Circle a number.)

\section{Statement:}

a: ecovar is an acceptable source of native plant material.

12234456

b: cultivar is an acceptable source of native plant material.

1232455

c: wild harvesting is an acceptable source of native plant material. $1123 \quad 3 \quad 4 \quad 5 \quad 0$

Figure 12. Ecovar is an acceptable source of native plant material $(n=34)$

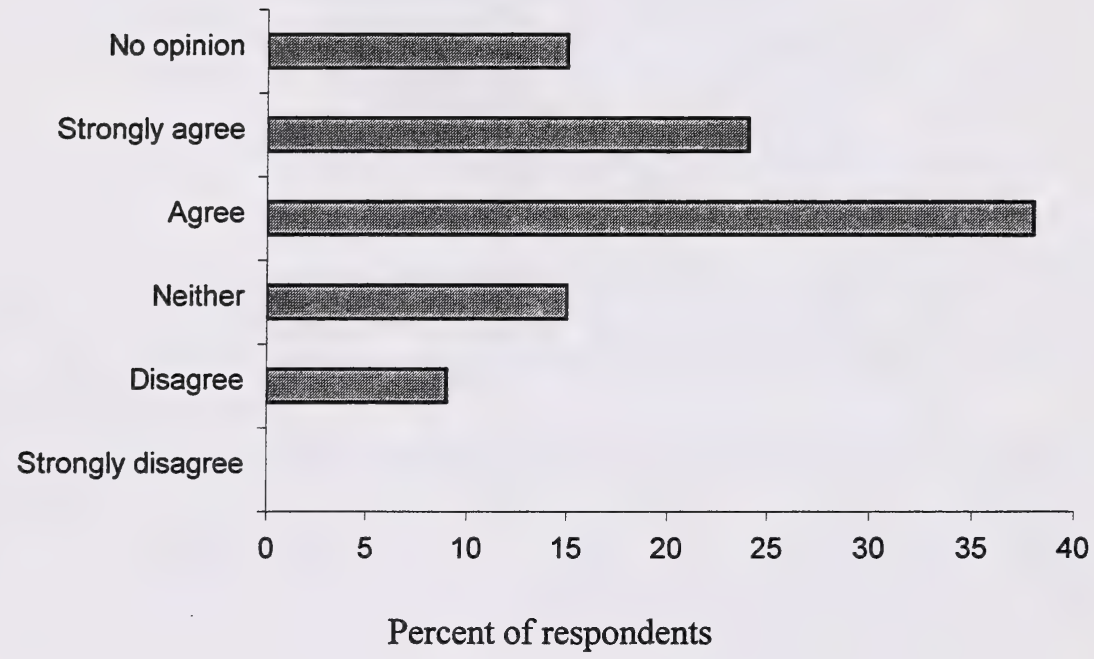

Sixty two percent of the respondents felt that an ecovar is an acceptable source of native plant material.

Eight percent do not feel it is an acceptable source. 
Figure 13. Cultivar is an acceptable source of native plant material $(n=33)$

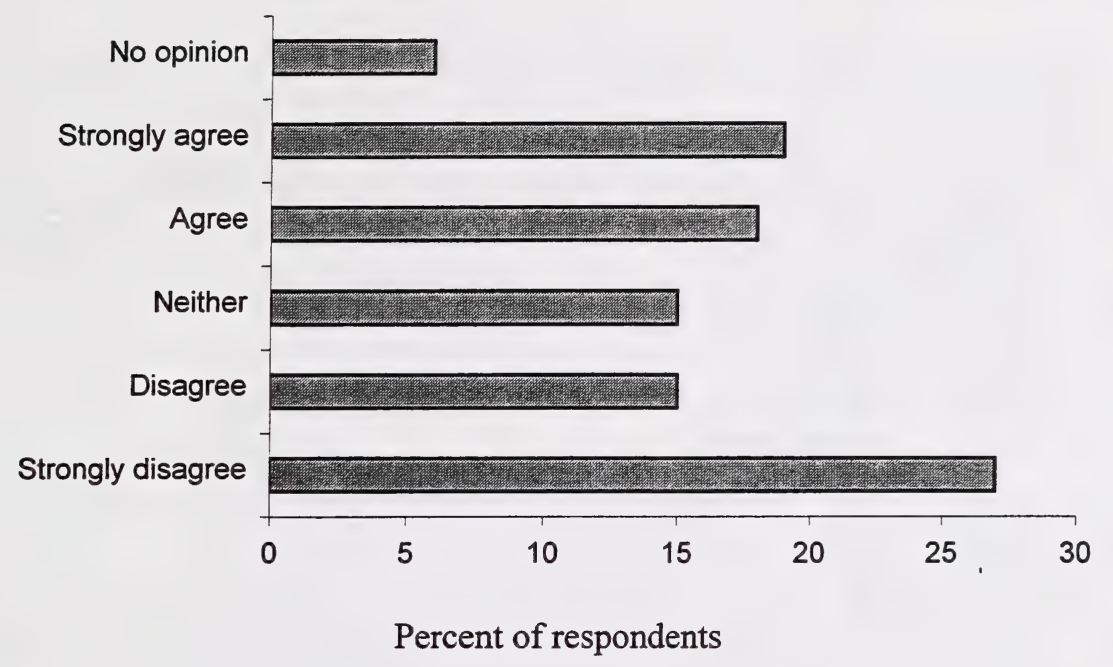

Thirty seven percent of the respondents felt that a cultivar is an acceptable source of native plant material while $42 \%$ of the respondents disagree with this statement. Fifteen percent of the respondents neither agree nor disagree and $6 \%$ of the respondents have no opinion.

Figure 14. Wild harvesting is an acceptable source of native plant material $(\mathrm{n}=32)$

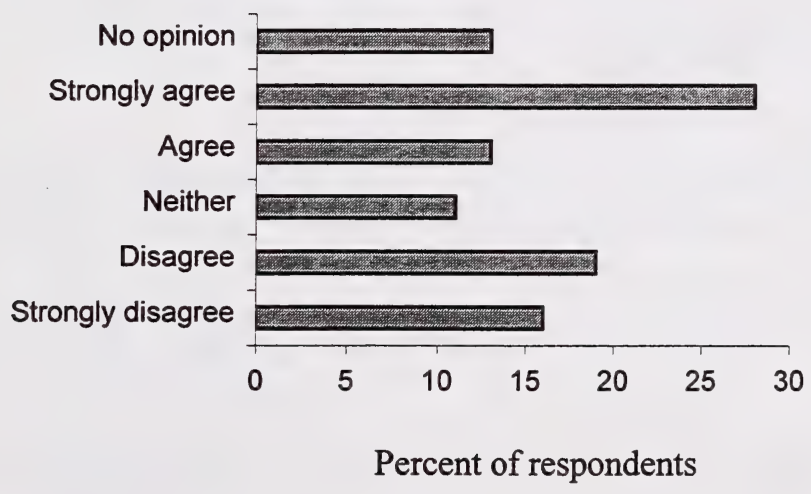

Forty one percent of the respondents agree that wild harvesting is an acceptable source of native plant material while $35 \%$ disagree with this statement. 
14. Please identify your 1998 and 1999 production by species and variety, including, amount sold and place of seed origin.

Table 6. Amount of native species sold during 1998 and 1999 and the ecoregions the plant materials originated from.

\begin{tabular}{|c|c|c|c|c|c|c|c|c|c|c|c|c|c|}
\hline & \multicolumn{2}{|c|}{1998} & \multicolumn{2}{|c|}{1999} & \multicolumn{9}{|c|}{ Ecoregions } \\
\hline & $\begin{array}{l}\text { Seed } \\
(\mathrm{kg})\end{array}$ & $\begin{array}{l}\text { Number } \\
\text { of } \\
\text { plants }\end{array}$ & $\begin{array}{l}\text { Seed } \\
(\mathrm{kg})\end{array}$ & $\begin{array}{l}\text { Number } \\
\text { of } \\
\text { plants }\end{array}$ & G.P & Tun & Taig & A.cord & NADst & NWFMt. & N.for & Othe & Jnk. \\
\hline Grasses & $\begin{array}{c}299,450 \\
(\mathrm{n}=32)\end{array}$ & $\begin{array}{l}13,930 \\
(n=13)\end{array}$ & $\begin{array}{c}387,425 \\
(\mathrm{n}=37)\end{array}$ & $\begin{array}{c}9,950 \\
(n=13)\end{array}$ & 21 & 0 & 0 & 0 & 0 & 9 & 2 & 0 & 0 \\
\hline Forbs & $\begin{array}{c}214 \\
\mathrm{n}=(23)\end{array}$ & $\begin{array}{l}22,137 \\
(\mathrm{n}=60)\end{array}$ & $\begin{array}{c}34 \\
(n=18)\end{array}$ & $\begin{array}{l}42,678 \\
(\mathrm{n}=58)\end{array}$ & 44 & 0 & 0 & 0 & 0 & 0 & 0 & 0 & 0 \\
\hline $\begin{array}{l}\text { Woody } \\
\text { Plants }\end{array}$ & $\begin{array}{c}0.67 \\
(n=3)\end{array}$ & $\begin{array}{c}831,160 \\
(n=57)\end{array}$ & $\begin{array}{l}6,701 \\
(n=4)\end{array}$ & $\begin{array}{c}-717,020 \\
(\mathrm{n}=66)\end{array}$ & 34 & 0 & 0 & 0 & 0 & 1 & 0 & 25 & 0 \\
\hline $\begin{array}{l}\text { Wetland } \\
\text { Plants }\end{array}$ & $\begin{array}{c}0.1 \\
(n=1)\end{array}$ & $\begin{array}{c}1,800 \\
(n=10)\end{array}$ & 0 & $\begin{array}{l}2,700 \\
(n=12)\end{array}$ & 12 & 0 & 0 & 0 & 0 & 6 & 2 & 2 & 0 \\
\hline Total & 299,665 & 869,027 & 394,160 & 772,348 & 111 & 0 & 0 & 0 & 0 & 16 & 4 & 27 & 0 \\
\hline
\end{tabular}

Note. $\mathrm{N}$ equals the number of responses received. The number in the ecoregion columns shows the number of responses. Respondents sold their product in more than one ecoregion. Total responses recorded in the various categories of species are greater than the number of responses across the ecoregions because a number of respondents selling their product had not recorded the ecoregion the plant materials originated from. Details of species are in Appendix 2.

G.P. $=$ Great Plains

Tun $=$ Tundra

Taig $=$ Taiga

A.cord $=$ Arctic Cordillera

NADst $=$ North American Deserts

NWFMt. $=$ Northwestern Forest Mountains

N.for $=$ Northern Forests

Approximately 250 native species of grasses, forbs, woody plants, sedges and wetland plants were sold during 1998 and 1999 . In 1999, native grass seed sales went up by $32 \%$ while plant sales decreased by $11 \%$.

Compared to 1998 , seed sales of forb plants decreased by six times and plant sales were up $94 \%$ in 1999.

Number of woody plants sold in 1999 decreased by $14 \%$ while seed sales increased significantly.

Sale of wetland plants increased by $50 \%$ in 1999 . 
The majority of plants were sold in the Great Plains (111 responses, followed by North Western Forest Mountain and Northern Forest).

Table 7. Species most commonly sold in 1998 and 1999.

\begin{tabular}{|c|c|c|}
\hline Categories & 1998 & 1999 \\
\hline $\begin{array}{l}\text { Grasses } \\
\text { (greater than } 10,000 \mathrm{~kg} \\
\text { of seed) }\end{array}$ & $\begin{array}{l}\text { Agropyron trachycaulum } \\
\text { Agropyron dasystachyum } \\
\text { Agropyron smithii } \\
\text { Agropyron riparium } \\
\text { Bromus carinatus } \\
\text { Festuca hallii } \\
\text { Poa alpina } \\
\text { Panicum capillare }\end{array}$ & $\begin{array}{l}\text { Agropyron trachycaulum } \\
\text { Agropyron dasystachyum } \\
\text { Agropyron smithii } \\
\text { Agropyron riparium } \\
\text { Bromus carinatus } \\
\text { Festuca hallii } \\
\text { Poa alpina } \\
\text { Panicum capillare }\end{array}$ \\
\hline $\begin{array}{l}\text { Wetland plants } \\
\text { (greater than } 100 \text { plants) }\end{array}$ & $\begin{array}{l}\text { Caltha palustris } \\
\text { Juncus ensifolius } \\
\text { Alisma plantago-aquatica } \\
\text { Eleocharis palustris } \\
\text { Petasites sagittatus } \\
\text { Myriophyllum exalbescens } \\
\text { Lemna minor } \\
\text { Hippuris vulgaris } \\
\text { Equisetum hyemale }\end{array}$ & $\begin{array}{l}\text { Carex aquatilis } \\
\text { Equisetum hyemale } \\
\text { Caltha palustris } \\
\text { Juncus ensifolius } \\
\text { Alisma plantago-aquatica } \\
\text { Eleocharis palustris } \\
\text { Petasites sagittatus }\end{array}$ \\
\hline $\begin{array}{l}\text { Forbs } \\
\text { (greater than } 1,000 \\
\text { plants) }\end{array}$ & $\begin{array}{l}\text { Caltha palustris } \\
\text { Rudbeckia hirta } \\
\text { Anemone patens } \\
\text { Liatris ligulistylis } \\
\text { Monarda fistulosa }\end{array}$ & $\begin{array}{l}\text { Caltha palustris } \\
\text { Rudbeckia hirta } \\
\text { Anemone patens } \\
\text { Liatris ligulistylis } \\
\text { Monarda fistulosa } \\
\text { Geum triflorum } \\
\text { Petalostemon purpureum } \\
\text { Heliopsis helianthoidesscabra } \\
\text { Antennaria rosea } \\
\text { Iris versicolor }\end{array}$ \\
\hline $\begin{array}{l}\text { Woody plants } \\
\text { (greater than } 10,000 \\
\text { plants) }\end{array}$ & $\begin{array}{l}\text { Picea glauca } \\
\text { Pinus contorta } \\
\text { Populus tremuloides } \\
\text { Populus balsamifera } \\
\text { Rosa acicularis } \\
\text { Alnus crispa } \\
\text { Salix exiqua } \\
\text { Amelanchier alnifolia } \\
\text { Arctosphylos uva-ursi } \\
\text { Cornus stolonifera } \\
\text { Rosa woodsii }\end{array}$ & $\begin{array}{l}\text { Picea glauca } \\
\text { Pinus contorta } \\
\text { Rosa acicularis } \\
\text { Alnus crispa } \\
\text { Salix exiqua } \\
\text { Amelanchier alnifolia } \\
\text { Arctosphylos uva-ursi } \\
\text { Cornus stolonifera } \\
\text { Rosa woodsii } \\
\text { Pinus banksiana }\end{array}$ \\
\hline
\end{tabular}




\section{Marketing/processing information}

15. How is your native plant material sold? Select all options, which are appropriate. (Sum to $100 \%$ ).

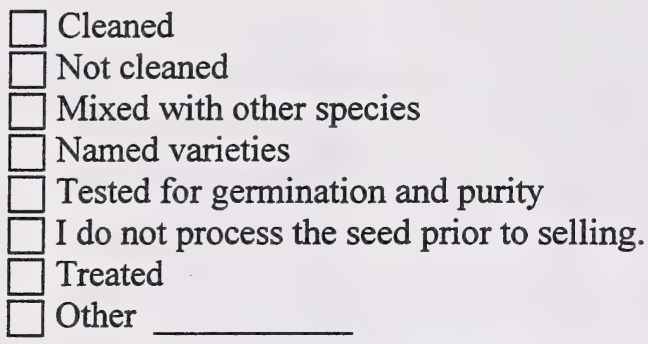

Figure 15. How is seed sold?

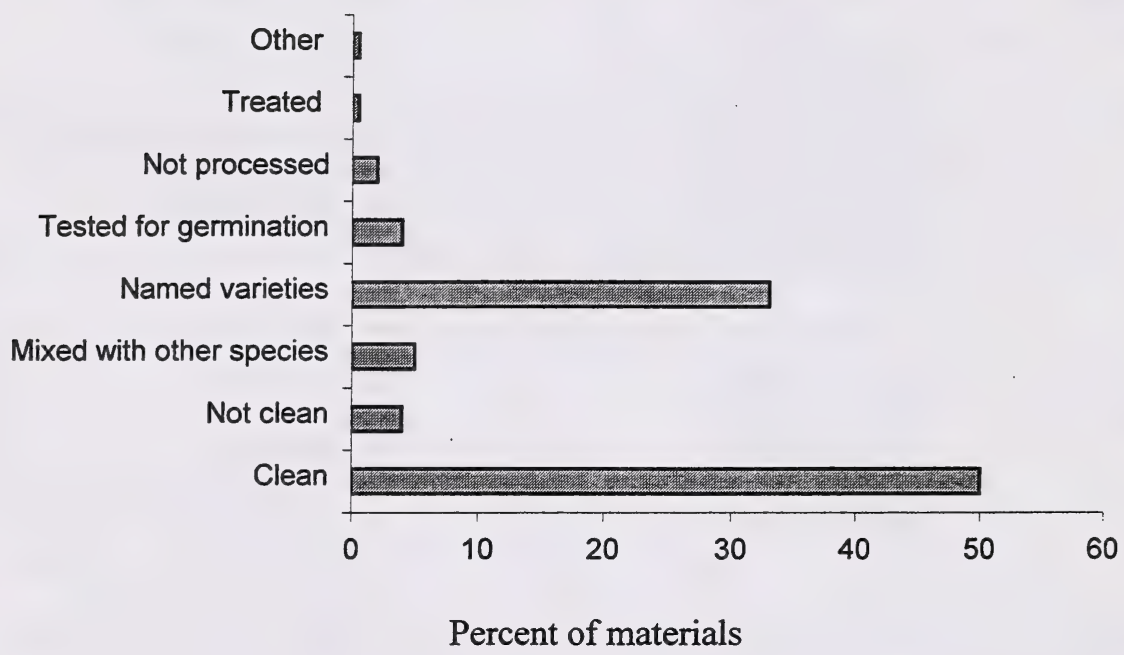

Only 18 respondents answered this question. Fifty percent of seeds were sold as clean seed and $30 \%$ of the seeds were named varieties. 
16. Do you sell all the native plant material in a typical year?

$\square$ Yes. carried over? $\%$.

Figure 16. Plant materials sold in a typical year $(n=12)$

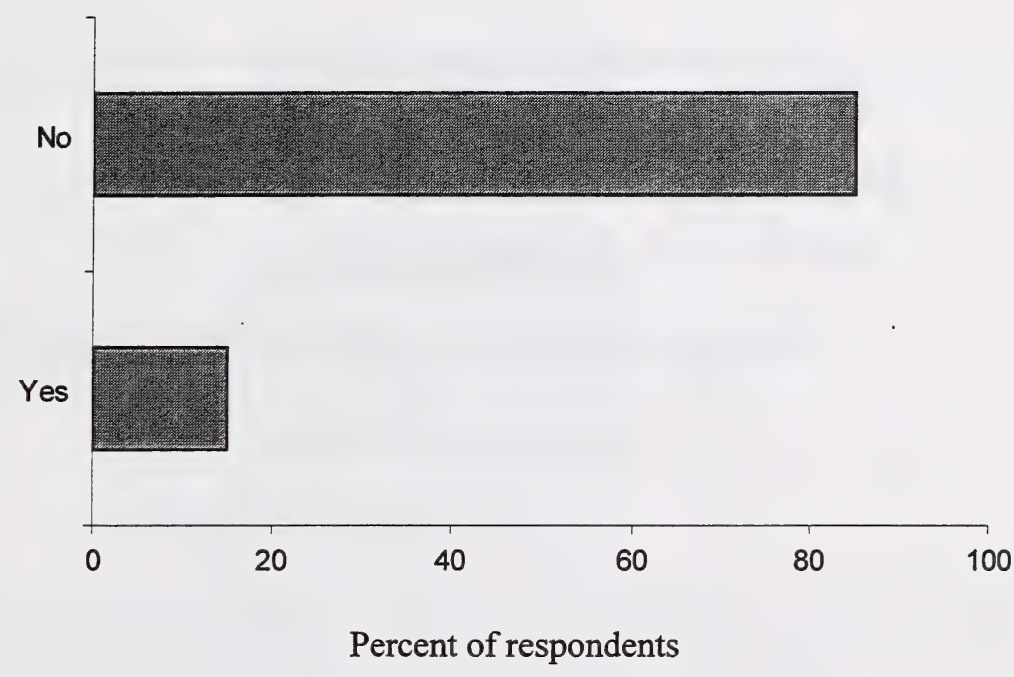

Only $15 \%$ of the respondents sold all the plant materials within a year. Eighty five percent have crops carried over to the next year.

On average, $38 \%$ of the plant material is carried over to the next year. 
17. What information do you provide to the users of native plant species?

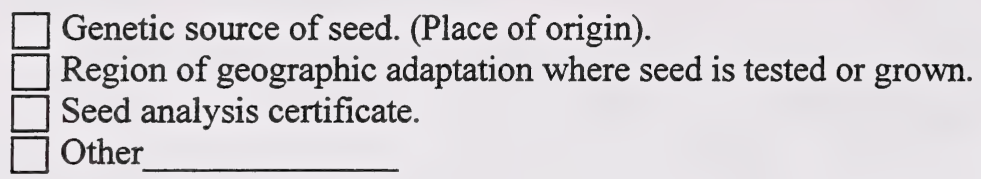

Figure 17. Information provided to users of native plants $(\mathrm{n}=39)$

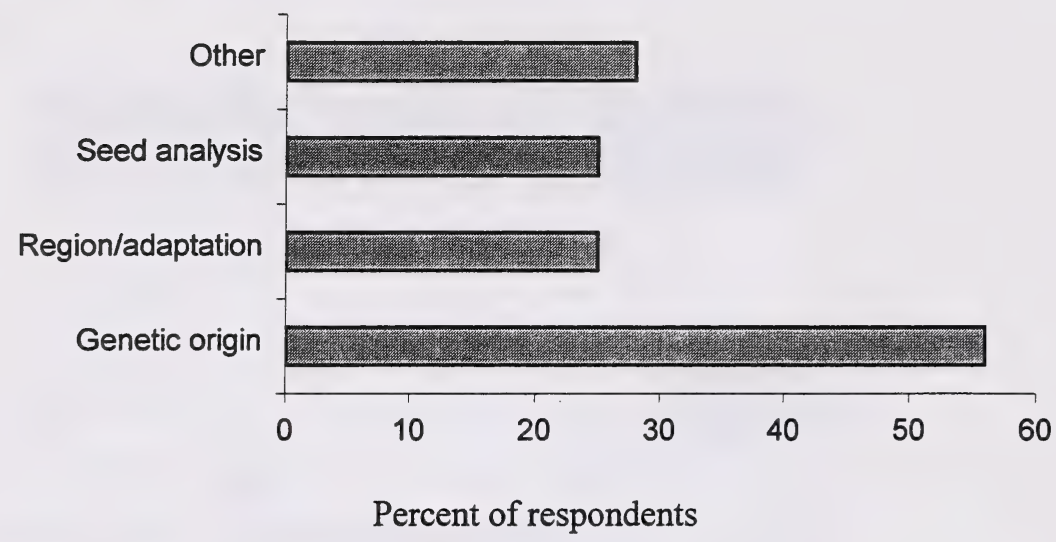

Fifty six percent of the respondents provided information on the genetic origin of the plant material. Twenty five percent provided information on the region where the plant material was obtained. Another twenty five percent provided information on seed analysis and $28 \%$ of the respondents received other type of information. Thirty four percent of the producers provided more than one piece of information.

Other information provided by the producers and suppliers included;

1. Catalogue,

2. Cultural requirements, compatible plants,

3. Date of harvest, scientific names,

4. Germination instruction, suggestions for site, description of soil and plant community,

5. Literature/additional information and advice concerning the species, planting, harvesting,

6. Pure live seeds, utilization. 
18. What percentage of the product is sold within the following distances from your place of business? Please fill in all that apply.

\begin{tabular}{l}
$\% 0-50 \mathrm{~km}$ \\
$\%$ \% $51-100 \mathrm{~km}$ \\
$\% 101-200 \mathrm{~km}$ \\
$\%$ Over $200 \mathrm{~km}$ \\
$\%$ Abroad (overseas) \\
\hline$\%$ Other (please specify)
\end{tabular}

Figure 18. Distances plant materials sold from main point of business $(n=33)$

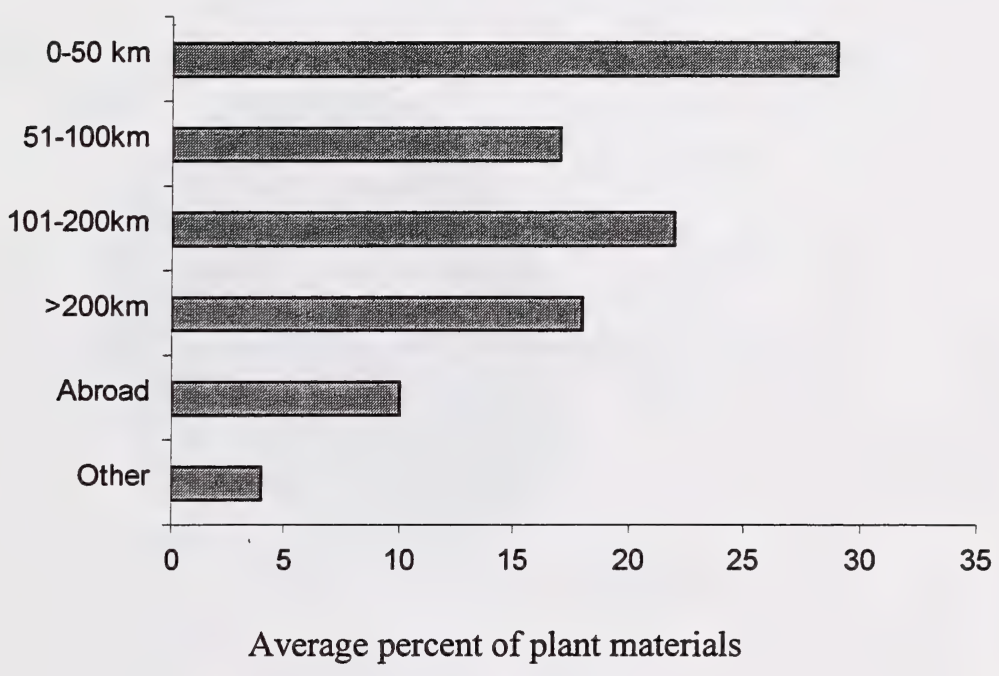

Most native plant materials are sold closer to the main point of business. However, both producers and suppliers will sell plant material over a wide area. Seventy five percent of the respondents sold their product at multiple distances from their main point of business.

"Other" localities include:

- United States, which includes Northern Minnesota, North Dakota, and Washington

- Alberta. 
19. Please identify the natural region where your native plant material sold last year, was used (check as many as apply). Sum up to $100 \%$.

$\square$ Grassland
$\square$ Parkland
$\square$ Foothills
$\square$ Rocky Mountains
$\square$ Boreal
$\square$ Don't know

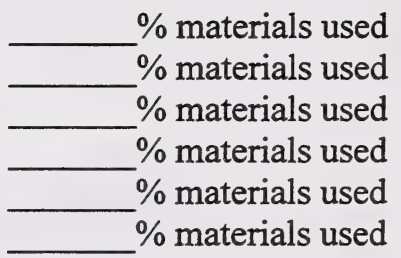

Figure 19. Average percent of materials used in the natural region $(n=32)$

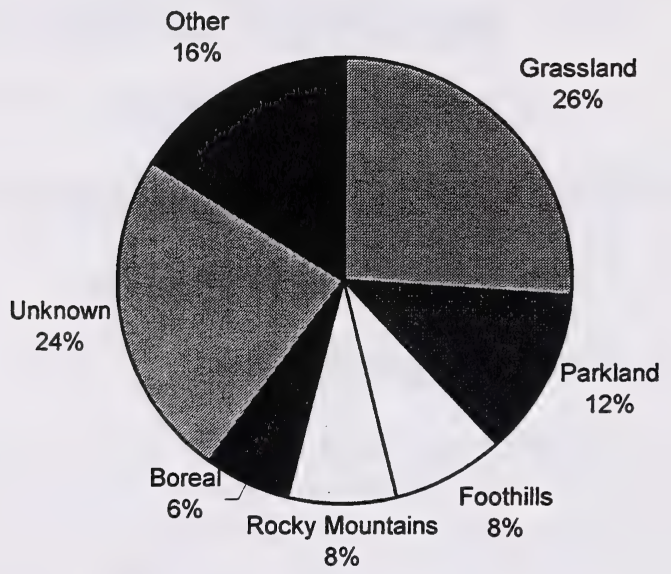

"Other" areas are Vancouver and Chilliwack, British Columbia.

Almost one quarter of the respondents do not know where the plant materials are being used. 
20. Please identify the ecoregion where your native plant material, sold last year, was used (check as many as apply). Sum up to $100 \%$.

$\square$ Great Plains
$\square$ Tundra
$\square$ Taiga
$\square$ Arctic Cordillera
$\square$ North American Desert
$\square$ North Western Forest Mountain
$\square$ Northern Forest
$\square$ Other
$\square$ Don't know

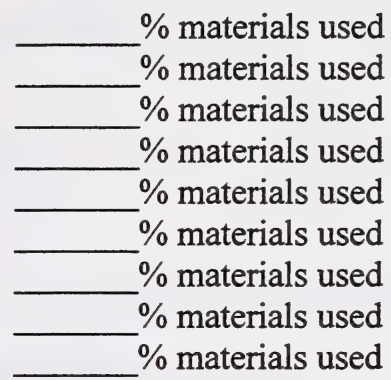

Figure 20. Ecoregions where native plant materials were used $(\mathrm{n}=26)$

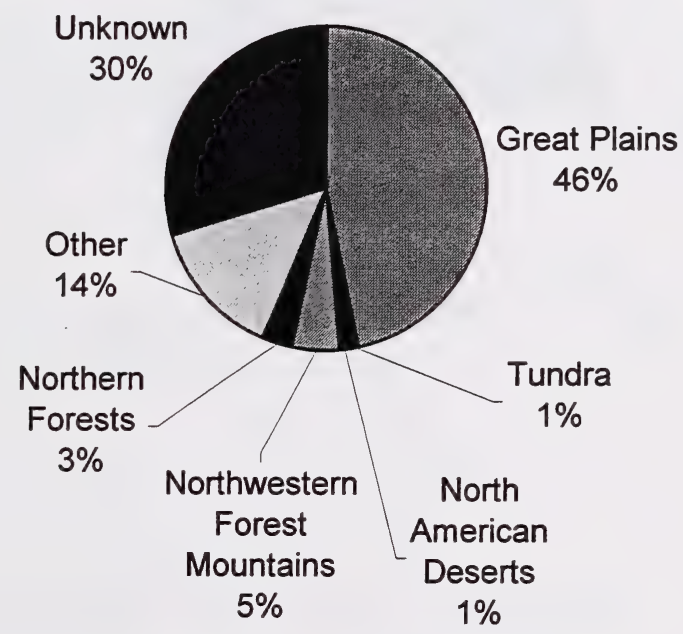

"Other" regions include Marine West Coast Forest and urban gardens.

Almost one third of the respondents do not know where the plant materials are being used. 
21. Please identify the province where your native plant material sold last year was used (check as many as apply). Sum up to $100 \%$.

$\square$ Alberta
$\square$ British Columbia
$\square$ Saskatchewan
$\square$ Manitoba
$\square$ United States (State
$\square$ Don't know

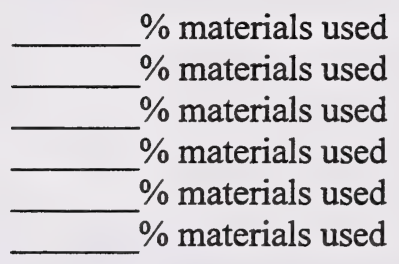

Figure 21. Average percent of native plant materials used by the various provinces $(n=38)$

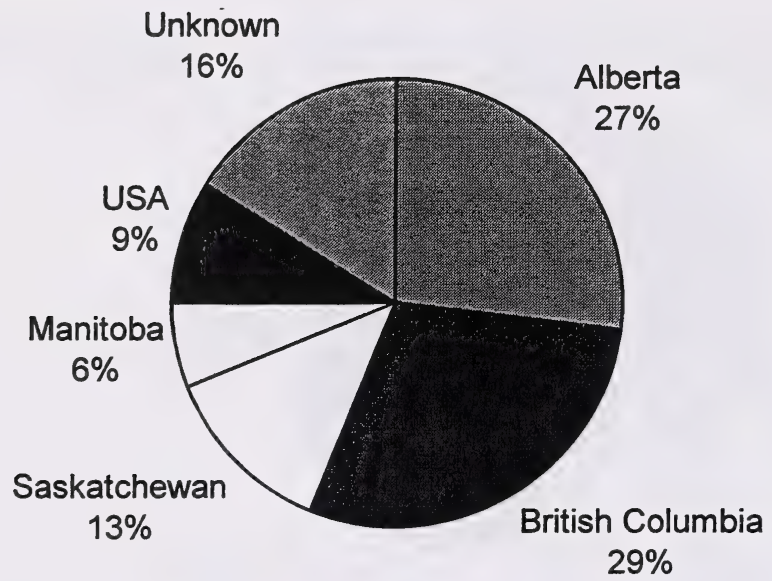

States in USA are: Minnesota, North Dakota, Washington, Oregon, and several other states.

Other provinces mentioned are Ontario, Quebec but no amounts were reported.

22. How do you market your products? Check all that apply.

$\square$ On-farm sales
$\square$ Contract
$\square$ Farmer's market
$\square$ Roadside stands
$\square$ Mail order
$\square$ Internet
$\square$ Other


Figure 22. Marketing means of native plants

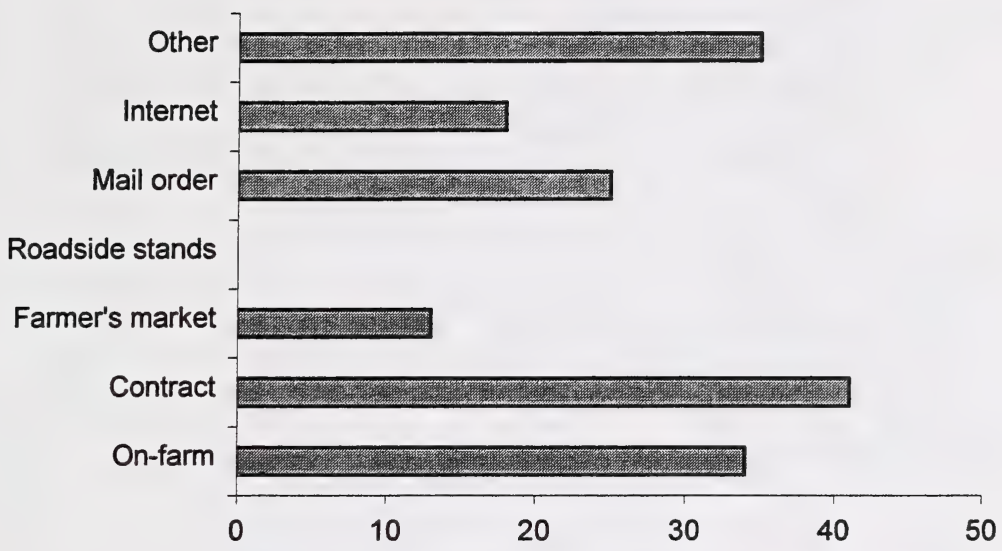

Percent of materials sold

Forty one percent of producers use contracts to market their products. That applies mostly to shrubs and tree seedlings for landscaping and reforestation. Thirty four percent of the plant materials are sold at the farm gate. Fifty seven percent of the respondents used multiple sales methods to market their product.

"Other" is listed below;

1. Brochures, pamphlets, faxes,

2. Consultants, Saskatchewan Native Plant Society,

3. Consignment,

4. Landscapers, resource companies, seed customers, garden centers,

5. Large seed companies,

6. Networking,

7. Retail nurseries,

8. Specialist meetings \& events,

9. Walk-in,

10. Wholesale, and

11. Word of mouth. 
23. What percentage of your product is sold to the following sectors Sum to $100 \%$.
(a) $\square$ Reclamation industry
- $\square$ oil \& gas
- $\square$ sand \& gravel
- $\square$ railways \& roadways
(b) $\square$ Agriculture
(c) $\square$ Horticulture
(d) $\square$ Landscaping
(e) Wildlife habitat restoration
(f) $\square$ Wetland restoration
(g) $\square$ Medicinal uses
(h) $\square$ Reforestation

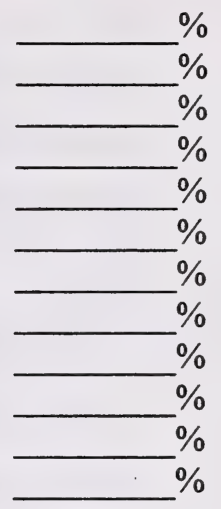

Figure 23. Average percent of native plant materials used by various industries $(n=33)$.

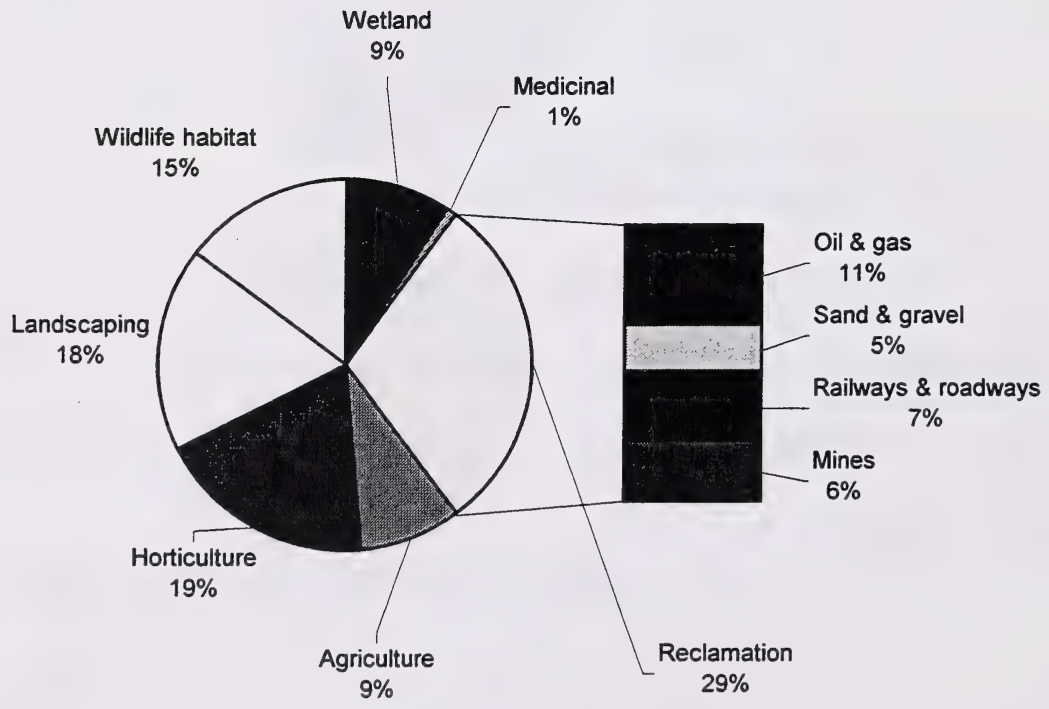


Table 8. Long- term forecast of native plant production.

\begin{tabular}{|l|c|c|c|c|c|c|}
\hline & \multicolumn{2}{|c|}{2000} & \multicolumn{2}{c|}{2002} & \multicolumn{2}{c|}{2005} \\
\hline Species & $\begin{array}{c}\text { Seed } \\
(\mathbf{k g})\end{array}$ & $\begin{array}{c}\text { \# of } \\
\text { plants }\end{array}$ & $\begin{array}{c}\text { Seed } \\
(\mathbf{k g})\end{array}$ & $\begin{array}{c}\text { \# of } \\
\text { plants }\end{array}$ & $\begin{array}{c}\text { Seed } \\
(\mathbf{k g})\end{array}$ & $\begin{array}{c}\text { \# of } \\
\text { plants }\end{array}$ \\
\hline & & & & & & \\
\hline Grasses & $\begin{array}{c}130,001 \\
(\mathrm{n}=17)\end{array}$ & $\begin{array}{c}2,100 \\
(\mathrm{n}=3)\end{array}$ & $\begin{array}{c}192,200 \\
(\mathrm{n}=19)\end{array}$ & 0 & $\begin{array}{c}184,700 \\
(\mathrm{n}=18)\end{array}$ & 0 \\
\hline & & & & & & \\
\hline Forbs & 10 & 7,000 & 1,020 & 12,000 \\
$(\mathrm{n}=1)$ & $(\mathrm{n}=4)$ & $(\mathrm{n}=2)$ & 520 & $\begin{array}{c}4,000 \\
(\mathrm{n}=5)\end{array}$ \\
\hline & & & & & & \\
\hline $\begin{array}{l}\text { Woody } \\
\text { plants }\end{array}$ & 0 & 12,000 \\
& & 0 & $\begin{array}{c}10,000 \\
(\mathrm{n}=1)\end{array}$ & 0 & $\begin{array}{c}10,000 \\
(\mathrm{n}=1)\end{array}$ \\
\hline & & & & & & \\
\hline $\begin{array}{l}\text { Wetland } \\
\text { plants }\end{array}$ & 0 & $\begin{array}{c}15,000 \\
(\mathrm{n}=29)\end{array}$ & 0 & $\begin{array}{c}4,300 \\
(\mathrm{n}=12)\end{array}$ & 0 & $\begin{array}{c}5,750 \\
(=12)\end{array}$ \\
\hline
\end{tabular}

Note: $\mathrm{N}$ equals number of responses received. For a detailed list of species, see Appendix 3.

25. Are any of the species targeted for future production, based on information provided in the (Check all that apply).

$\square$ Guide to Using Native Plants on Disturbed Lands. By H. Gerling, M. Willoughby.

A. Schoepf, C. Tannas and K.Tannas. 1996.

$\square$ Recommended Native Grasses and Legumes for Revegetating Disturbed Lands in the Green Area. Land and Forest Service. Alberta Environmental Protection. 1996.

$\square$ Guidelines as set up by Public Lands, Alberta Agriculture, Food and Rural Development: Appendix F-Commercial availability of native plant and Appendix $\mathrm{H}$ - Available native plant for use in Alberta.

I follow some other guidelines. (Specify)

Speculation.

None of the above. 
Figure 24. Information used to target production $(\mathrm{n}=29)$

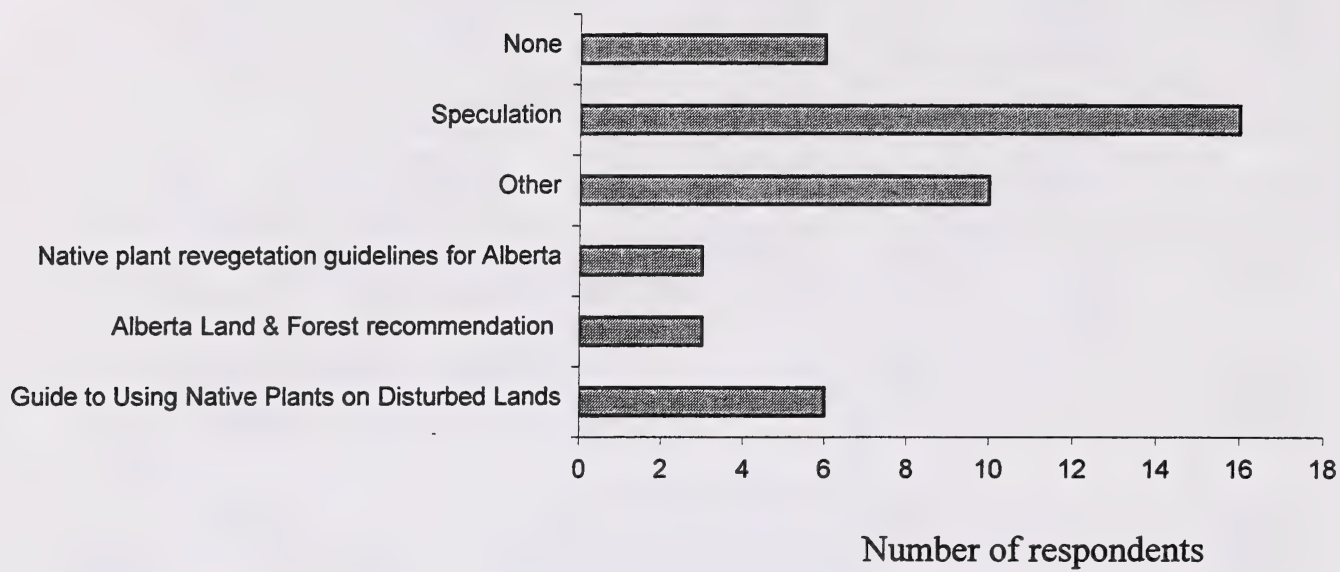

More than half of the respondents based their production targets on speculation of market demand. Twenty eight percent of the respondents used multiple sources of information when targeting production.

"Other" options used when planning native plant production include:

1. British Columbia Lands and Landscapes,

2. Customer recommendations,

3. Common sense,

4. Demand by garden centres,

5. Experience from observation,

6. Growing Native Plants of Western Canada, and

7. Other books (unlisted). 
Native Plant User Survey 


\section{B. Native Plant User Survey}

$$
(n=22)
$$

1. For how many years have you been using native plant materials?

Figure 25. Years using native plant materials

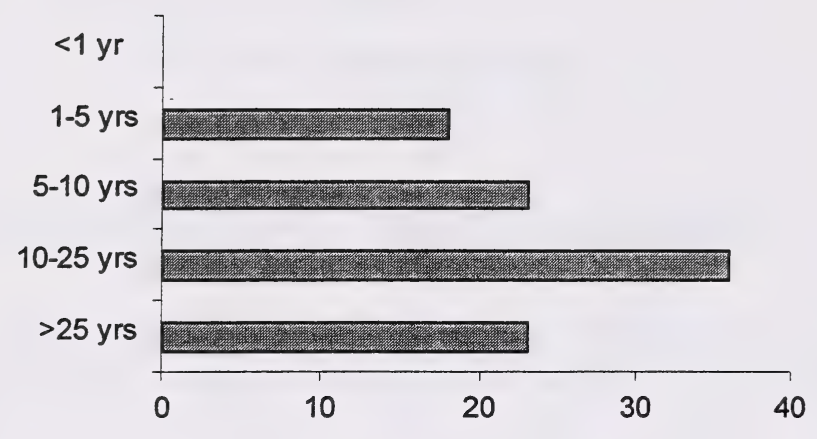

The majority of the respondents ( $58 \%$ ) have been using native plants for more than 10 years. 
2. I do not use native plants because. (Please check as many as apply.)

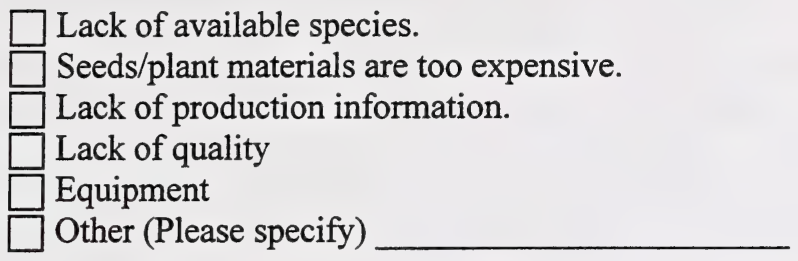

Figure 26. Reasons for not using native plant material $(\mathrm{n}=6)$

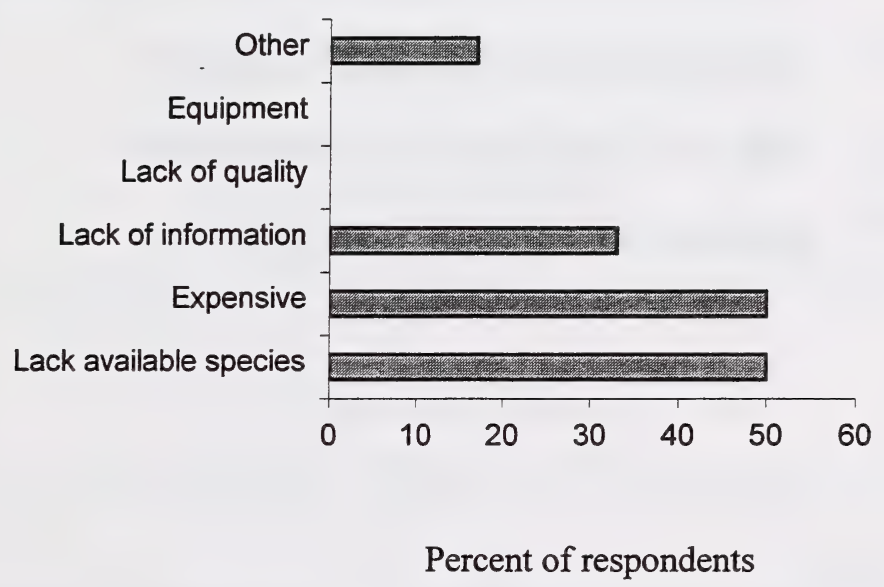

Lack of availability of species (50\%) and native seeds being expensive (50\%) are the most common responses as to why native plants were not used. A lack of information (33\%) concerning native plant materials was also a relevant issue.

Fifty percent of the respondents have more than one reason for not using native plants.

" Other" response included:

- Has not been requested on public lands for the forest industry. 
3. Why are native plant materials used in your particular industry? (Please check as many as apply.)

$\square$ Native plants performed better than introduced species.

Because of changing regulation governing the industry.

Increase diversity.

Other (Please specify)

Figure 27. Reasons for using native plants in your particular industry $(\mathrm{n}=21)$

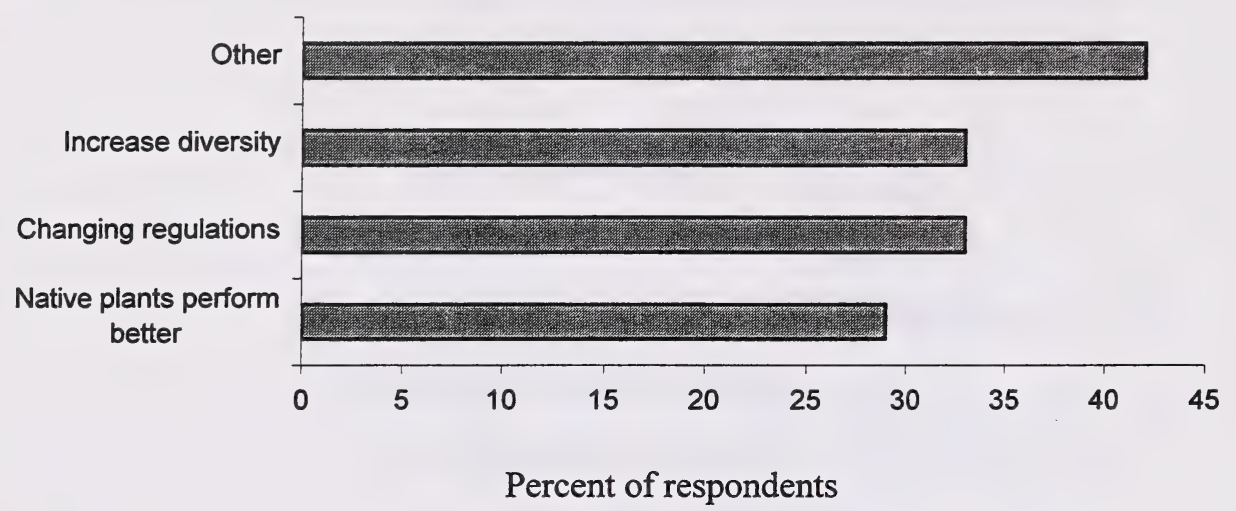

Thirty eight percent of the respondents have multiple reasons for using native plants.

"Other" reasons included:

1. Aesthetic value,

2. Conservation of mixed grass prairie,

3. Increased awareness of the use of native plant,

4. Less invasive in rangeland and more palatable to livestock,

5. Preserving the natural ecosystems, and

6. Research. 
4. For each statement below, please rate on a scale of 1 to 5 (1 being strongly disagree, 5 strongly agree and 0 being no opinion.) your level of agreement of each statement. (Circle a number.)

\section{Statement:}
a: ecovar is an acceptable source of native plant material.
122345
123345
0
b: cultivar is an acceptable source of native plant material.
c: wild harvesting is an acceptable source of native plant material. $\begin{array}{lllll}1 & 2 & 3 & 4\end{array}$
0

Figure 28. Ecovar is an acceptable source of native plant material $(\mathrm{n}=20)$

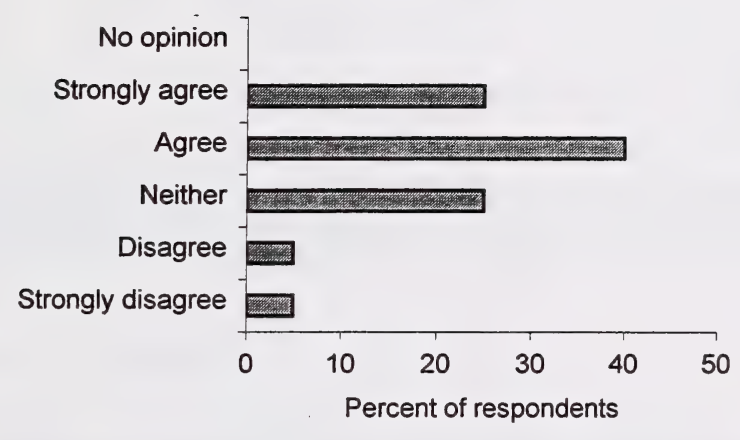

$65 \%$ of respondents agree that ecovar is an acceptable source of native plant material. Only $8 \%$ of the respondents disagree with this statement. 
Figure 29. Cultivar is an acceptable source of native plant material $(\mathrm{n}=19)$

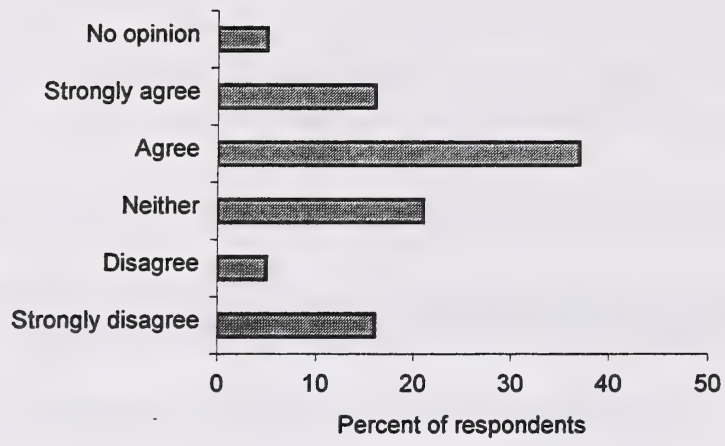

Fifty eight percent of the respondents agree to the statement that cultivar is an acceptable source of native plant material. Twenty one percent of the respondents disagreed with this statement.

Figure 30. Wild harvesting is an acceptable source of native plant material $(\mathrm{n}=19)$

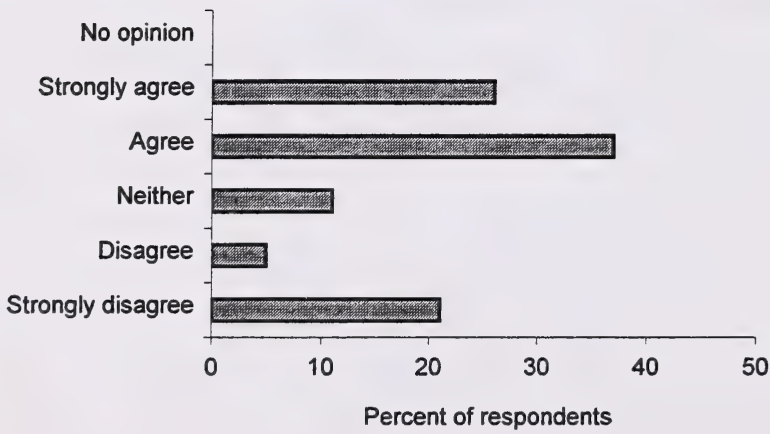

Sixty three percent of the respondents feel that wild harvesting is an acceptable source of native plant material. Twenty-six percent disagree with this method of obtaining native plant materials. 
5. Please complete the following table. For each species of grass, wildflower (forb \& legume), and shrub provide the quantity purchased, amount spent (\$), and the ecoregion in which the seed/plant was used.

Table 9. Amount of native species purchased and the ecoregion the plant materials were used during 1997,1998 , and 1999.

\begin{tabular}{|c|c|c|c|c|c|c|c|c|c|c|c|c|}
\hline & \multicolumn{3}{|c|}{1997} & \multicolumn{3}{|c|}{1998} & \multicolumn{3}{|c|}{1999} & \multicolumn{3}{|c|}{ Ecoregions } \\
\hline & $\mathrm{Kg}$. & No. & & $\mathrm{Kg}$. & No. & & $\mathrm{Kg}$. & No. & & GP & Boreal & NWFM \\
\hline & Seed & Pits & (\$) & Seed & Plts & (\$) & Seed & PIts & (\$) & & & \\
\hline Grasses & $\begin{array}{l}2,468 \\
(n=23)\end{array}$ & 0 & 53,675 & $\begin{array}{l}2,245 \\
(n=7)\end{array}$ & 0 & 1,850 & $\begin{array}{l}2,708 \\
(n=17)\end{array}$ & 0 & 48,619 & 35 & 7 & 3 \\
\hline Forbs & 10 & & & & & & & & & 5 & & \\
\hline & & & & & & & & & & & & \\
\hline Woody & 0 & $\begin{array}{c}165,050 \\
(n=8)\end{array}$ & 1,550 & & $\begin{array}{c}78,000 \\
(n=7)\end{array}$ & 630 & 0 & $\begin{array}{l}82,530 \\
(n=10)\end{array}$ & 1,000 & & 12 & 10 \\
\hline Total & 2,478 & 165,050 & $\$ 55,225$ & 2,245 & 78,000 & $\$ 2,480$ & 2,708 & 82,530 & $\$ 49,619$ & 40 & 19 & 13 \\
\hline
\end{tabular}

Note. $\mathrm{N}$ equals number of responses received. Not all respondents knew the ecoregion the plant material came from.

$\mathrm{GP}=$ Great Plains

NWFM $=$ Northwestern Forest Mountains

The amount of plant materials consumed and the amount of money spent by the users seemed small. In reality a greater number of species are being used, as many users indicated that they do not keep a record of the species or the amount of money spent on the purchase of native plant materials. Only 4 users have provided information on expenditures in 1997 and 1999 and only 2 of them have provided the same information for 1998. Most of the plant materials (do not include trees) are used in the Great Plains ecoregion. 
6. Which of the following sectors best represent the industry for which you have purchased any of the native plant materials? Also, please indicate the amount (percent) of seeds or plants species used in each of these sectors.

(a) $\square$ Reclamation industry

- $\square$ oil \& gas

- $\square$ sand \& gravel

- $\square$ railways \& roadways

- $\square$ mines

(b) $\square$ Agriculture

(c) $\square$ Horticulture

(d) $\square$ Landscaping

(e) Wildlife habitat restoration

(f) $\square$ Wetland restoration

(g) $\square$ Medicinal uses

(h) $\square$ Landfill

(i) $\square$ Reforestation

(j) $\square$ Other

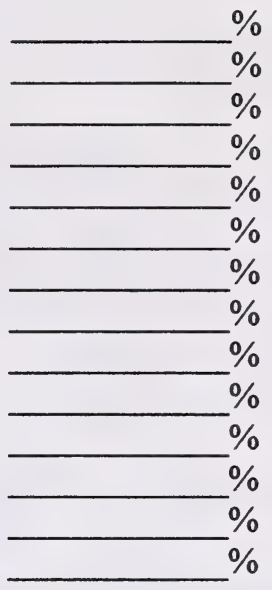

Figure 31. Industry sectors using native plant materials $(\mathrm{n}=35)$

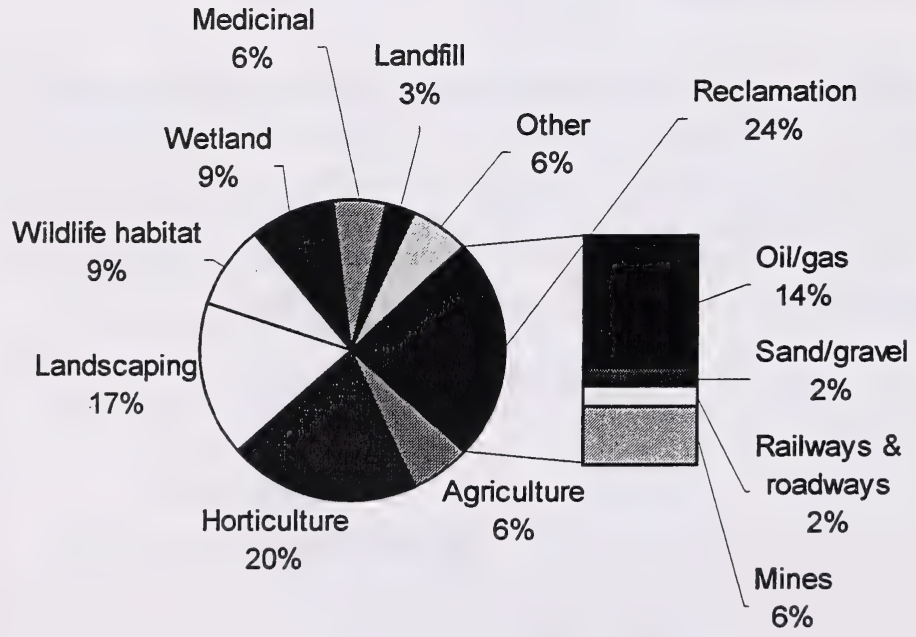

"Other" 6\% includes:

1. Prairie restoration.

2. Tree seedling production. 
7. What is the distance between your place of business and your native plant materials grower or supplier?

\section{Grower}

$\begin{aligned} & 0-50 \mathrm{~km} \\ & 51-100 \mathrm{~km} \\ & 101-200 \mathrm{~km} \\ & \text { Over } 200 \mathrm{~km}\end{aligned}$

$\square$ Other (Please specify)

\section{Supplier}

\begin{tabular}{c}
$0-50 \mathrm{~km}$ \\
$51-100 \mathrm{~km}$ \\
$101-200 \mathrm{~km}$ \\
\hline Over $200 \mathrm{~km}$ \\
$\square$ Other (Please specify)
\end{tabular}

Figure 32. Distance between business place and the grower/supplier $(\mathrm{n}=14)$

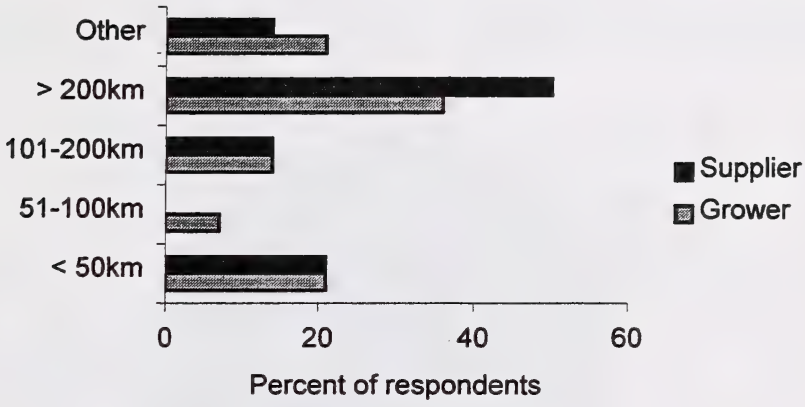

About $50 \%$ of the respondents received their plant materials from a distance of more than $200 \mathrm{~km}$.

"Other" - no details were provided. 
8. Please identify the ecoregion where the native plant materials bought were used, (check as many as apply). Please refer to ecoregion map.

$\square$ Great Plains
$\square$ Tundra
$\square$ Taiga
$\square$ Arctic Cordillera
$\square$ North American Desert
$\square$ Northern Forest
$\square$ North Western Forest Mountain
$\square$ Other
$\square$ Don't know

$\%$ materials used $\%$ materials used $\%$ materials used $\%$ materials used $\%$ materials used $\%$ materials used $\%$ materials used $\%$ materials used

Figure 33. Average percent of material used by ecoregion $(n=15)$

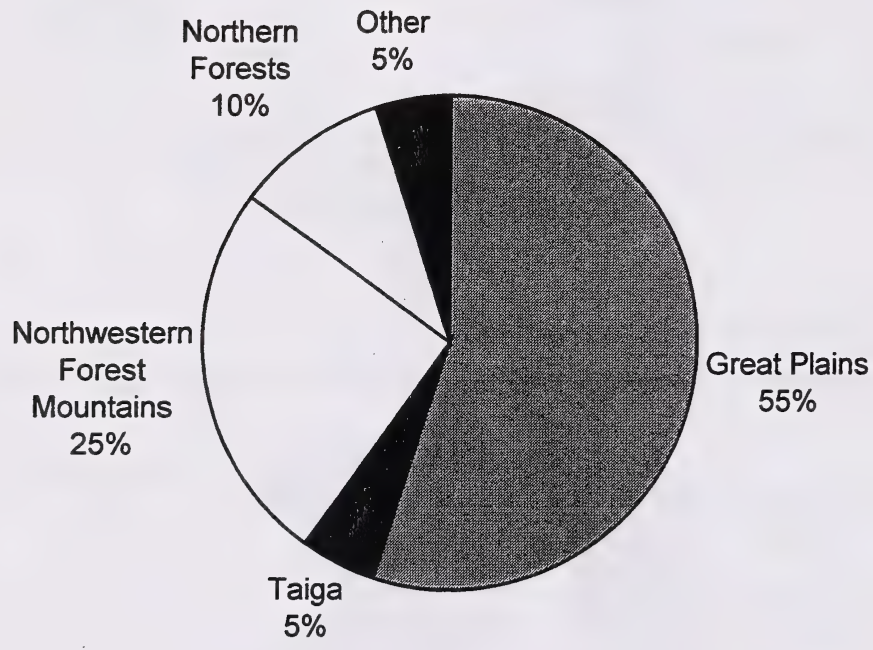

Other reported (5\%) but no specifics were given. 
9. Please identify the geographical area where the native plant materials bought were used, (check as many as apply).

$\square$ Grassland
$\square$ Parkland
$\square$ Foothills
$\square$ Rocky Mountains
$\square$ Boreal
$\square$ Don't know

$\begin{array}{r}\% \text { materials used } \\ \% \text { materials used } \\ \% \text { materials used } \\ \hline \% \text { materials used } \\ \hline \% \text { materials used } \\ \hline \% \text { materials used }\end{array}$

$\underline{\text { Figure 34. Average percent of material used by geographical area }(\mathrm{n}=15)}$

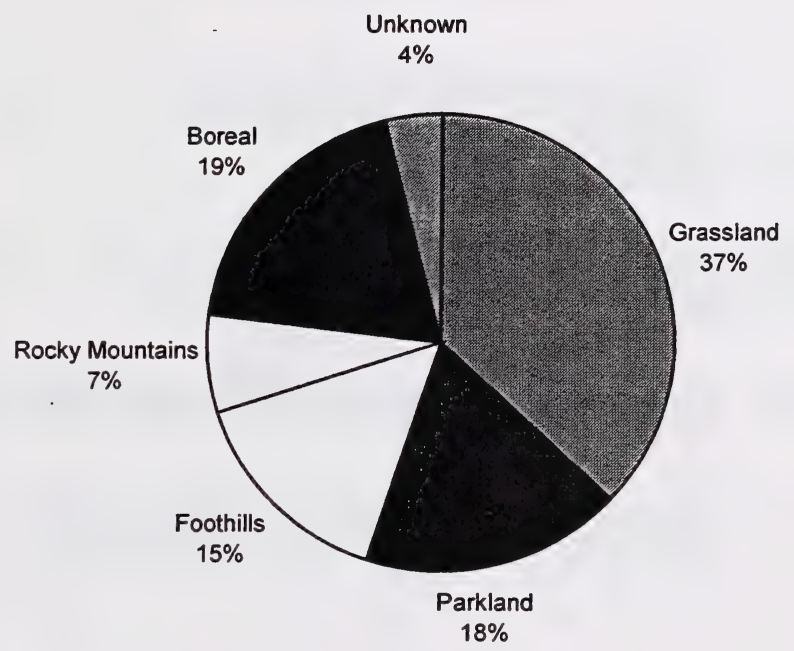

Four percent stated they did not know where their native plant material was used. 
10. Do you know the geographical origin (original genetic source) of the native plant material you purchased last year or in past years?

I know the geographical origin of all native plant materials I purchased. I know the geographical origin of some native plant materials I purchased.

I do not know the geographical origin of any native plant materials I purchased, wish I did.

$\square$ I do not know the geographical origin of any native plant materials I purchased, but it does not matter.

Figure 35. Knowledge of original genetic source of the plant material purchased $(n=19)$

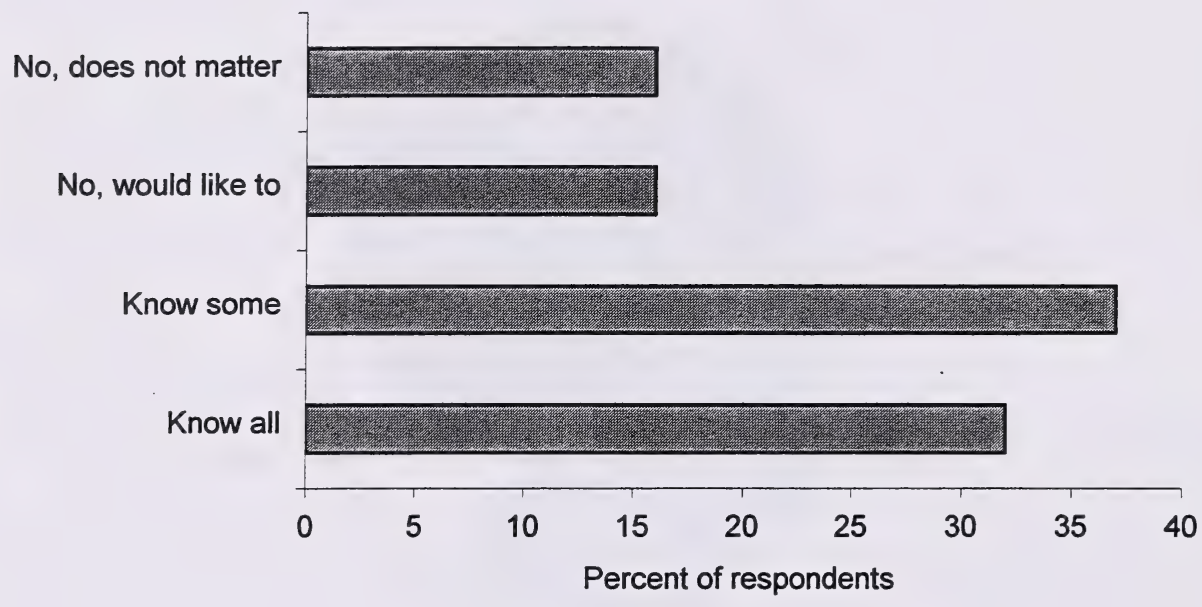

Sixty-nine percent of the respondents reported they were informed of at least some or all of the genetic sources of the material they purchased. Sixteen percent reported they were given no information but would have preferred to know and $16 \%$ reported that it did not matter to them if they were provided with the information. 
11. Does the grower/supplier provide you with any information regarding the native plant materials you purchased?

$\square$ Seed analysis

$\square$ Source of seed

$\square$ None (purity \& germination)

Figure 36. Information provided regarding native plant material purchased $(\mathrm{n}=20)$

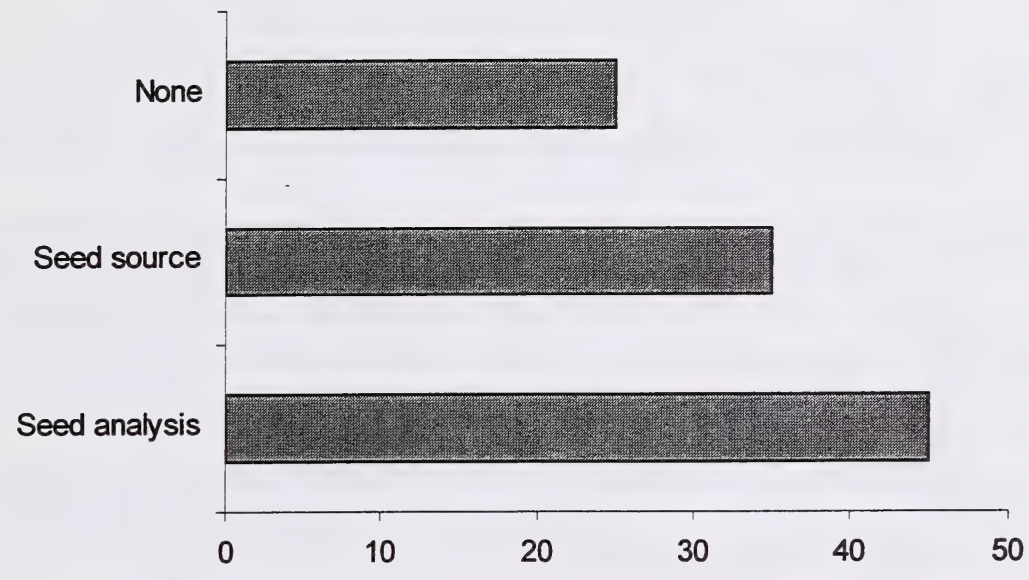

One respondent (5\%) provided more than one piece of information.

12. In your opinion, what has to be done to increase the use of native species.

$\square$ Increase research for development of native species.

Increasing public awareness on the use of native species by holding workshops, etc.

Other (Please specify) 
Figure 37. How to increase the use of native plant materials ( $n=20)$

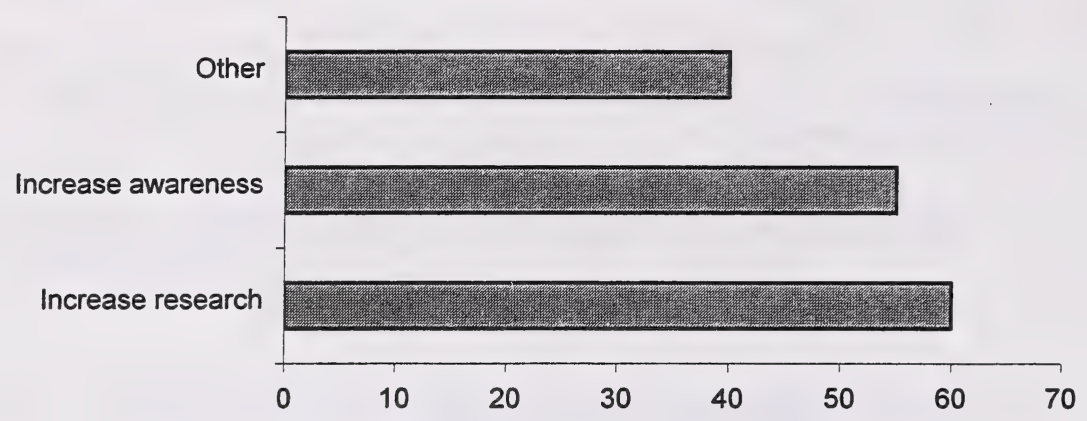

Percent of respondents

Sixty five percent of the respondents provided multiple reasons for increasing the use of native plants. Respondents tended to agree that the native plant industry needs more research (60\%) and increased awareness (55\%). Other (40\%) gave suggestions on how to increase use of native plants. These included:

1. Educate and inform public and industry,

2. Increase selection and supply,

3. Limit wild harvesting,

4. Lower prices,

5. More information on cultivar development,

6. Tighten government regulations, and

7. Regulations should be more clearly defined, re: Native Plant Policy.

13. Please fill the following table, based on your anticipated use of native plants in the year 2000 and 2001.

Table 10. Projected use and ecoregion of native plant material in 2000 and 2001.

\begin{tabular}{|c|c|c|c|c|c|c|c|}
\hline & \multicolumn{4}{|c|}{ Projected Use } & \multicolumn{3}{|c|}{ Ecoregions } \\
\hline & \multicolumn{2}{|c|}{2000} & \multicolumn{2}{|c|}{2001} & \multirow[b]{2}{*}{ GP } & \multirow[b]{2}{*}{ Boreal } & \multirow[b]{2}{*}{ NWMF } \\
\hline & (kg) & Plants & (kg) & Plants & & & \\
\hline Grasses & $\begin{array}{c}3,693 \\
(n=30)\end{array}$ & 0 & $\begin{array}{c}1,744 \\
(n=18)\end{array}$ & 0 & 23 & 6 & 1 \\
\hline Forbs & 0 & 0 & 0 & 0 & 0 & 0 & 0 \\
\hline $\begin{array}{l}\text { Wetland } \\
\text { Plants }\end{array}$ & 0 & 0 & 0 & 0 & 0 & 0 & 0 \\
\hline Woody & $\begin{array}{c}8.5 \\
(n=4)\end{array}$ & $\begin{array}{c}512,800 \\
(n=13)\end{array}$ & 0 & $\begin{array}{c}250,800 \\
(n=11)\end{array}$ & 0 & 9 & 8 \\
\hline Total & $3,701.5$ & 512,800 & 1,744 & 250,800 & 23 & 15 & 9 \\
\hline
\end{tabular}

Note. $\mathrm{N}$ equals number of responses received. Details are in Appendix 4. Only 9 users provided information for the year 2000 and 4 of them provided the same information for the year 2001. Ecoregions information is for year 2000 . 


\section{User Comments}

The following issues were raised by some of the users of native plants. These are:

1. Wild harvesting controls. Some suggested that harvesting from native landscapes should be restricted or even banned.

2. Information on ecovar and cultivar development. Users of native plant material wanted to have knowledge of what is happening in the research and development sector.

3. Information on weed control. Some of the respondents who have been using native plants do not know how to deal with weedy areas in their field. It was indicated that information on the use of herbicides on native species should be made available.

4. Improved government regulation. One respondent suggested that the government should have clear, defined guidelines.

5. Native plant producers group. Others indicated the need for a native plant producers group*. This can allow for easy sourcing of plant materials.

6. Alberta native plant guidelines need to be reviewed. One user indicated the need to review the native plant guidelines in Alberta.

\section{Conclusions}

There was a forty five percent response rate. Response by province was divided as follows, Alberta (39\%), British Columbia (29\%), Saskatchewan (15\%), Manitoba (11\%) and other provinces and the United States (6\%). This compares well to similar surveys done in Saskatchewan (37\%) and Minnesota (28\%).

The industry is no longer in its formative stage as suggested in past publications. It is growing steadily. Most commonly reported income bracket in 1998 was $\$ 25,000$ or less and the total gross income $(n=38)$ reported during that year was $\$ 7.03$ million. There is no significant relationship $(\mathrm{p}=0.26)$ between amount of time spent in the native plant business, years producing native plant materials and gross revenue. In reality the native plant industry is worth more than the $\$ 7.03$ million as many producers did not provide revenue information.

* The Native Plant Producers Association was formed in November of 1999. For more information, contact Ken Wright at (403) 686-4434 or e-mail to bowpoint@agt.net 
In 1998 over 250 different species of various plants were collected from native landscapes.

The amount collected varies among species and ranges from $10 \mathrm{gm}$ to $50 \mathrm{~kg}$ of seeds and from 10 plants to 10,000 plants*. In $1998,726 \mathrm{~kg}$ of seeds and 14,481 plants were collected from native landscapes.

In 1999 , the amount of seeds collected went down by $65 \%$ and the number of plants collected increased by over $80 \%^{\ddagger}$. A number of respondents indicate that they collected seeds and plants from native prairies but have not indicated the amount of plant materials collected. Over $50 \%$ of the activity occurred in the Great Plains ecoregion.

Grass species most commonly (based on the amount of plant material) collected during 1998 and 1999 are Poa palustris, Panicum capillare, and Calamagrostis purpurescens. Wetland plants included Myriophyllum exalbescens, Lemna minor, Sagittaria cuneata, Hippuris vulgaris and Carex aquatilis. The forbs include: Aster ericoides, Asclepias incarnata, Antennaria rosea and the shrubs are Rubus parviflorus, Amelanchier alnifolia, and Acer spp.

There were over 250 species of native plants in production during 1998 and 1999. In 1998, $299,450 \mathrm{~kg}$ of grass seed and 13,930 grass plants were produced. That number increased to $387,425 \mathrm{~kg}$ of grass seed and number of grass plants decreased to 9,950 in 1999. Forb production was 22,137 plants in 1998 and increased to 42,678 in 1999 . Similarly, production of wetland plants went up by $33 \%$ to 2,700 plants and woody plants went down by $13 \%$ to 717,020 plants. In total, the amount of native seed produced increased by $23 \%$ to $394,160 \mathrm{~kg}$ and number of plants decreased by $11 \%$ to 772,348 plants. Most commonly produced grass species in 1998 and 1999 are Agropyron trachycaulum, Agropyron smithii, Festuca hallii, Bromus carinatus, Poa alpina, Panicum capillare, Agropyron dasystachyum and Agropyron riparium.

The forb species with the highest demand in 1998 and 1999 included: Rudbeckia hirta, Monarda fistulosa, Iris versicolor, Anemone patens and Geum triflorum.

* Did not provide details on whether the whole plant or parts of the plant were collected.

\footnotetext{
${ }^{\ddagger}$ No reasons were provided for the decrease in the amont of seed and increase in the number of plants collected from native landscapes during 1999.
} 
The woody species with the highest demand in 1998 and 1999 included: Picea glauca, Populus tremuloides, Populus balsamifera, Rosa acicularis, Salix exiqua, Amelanchier alnifolia, Cornus stolonifera and Alnus crispa. The most commonly produced wetland species included: Caltha palustris, Carex aquatilis, Equisetum hyemale, Lemna vulgaris, and Alisma plantago-aquatica.

Most of the plant materials sold were used in the grassland region (26\%), followed by Parklands and Foothills with $12 \%$ and $8 \%$ respectively. Producers and suppliers did not know where $40 \%$ of the materials were to be used. There may be an opportunity here for producers and suppliers to work with end users of native plant in determining market trend. The producers identified that $46 \%$ of the plant materials are sold in the Great Plains. British Columbia and Alberta accounted for $56 \%$ of the native plant materials used. About $9 \%$ of plant materials are sold to Minnesota, North Dakota, Washington and Oregon.

Producers indicate that they sold native plants materials to various industries. These included: horticulture (19\%), landscaping (18\%), wildlife habitat mitigation $(15 \%)$, agriculture $(9 \%)$, wetland restoration (9\%), medicinal uses (1\%), and reclamation (29\%). The reclamation sector was further divided into oil and gas (11\%), sand and gravel (5\%), railways and roadways $(7 \%)$, and mines (6\%).

A user survey was also developed and sent out to a group of users or potential users of native plants, representing the various sectors of the industry in Alberta. It was meant to obtain some additional information from a user's point of view.

Of the users surveyed $(n=22), 36 \%$ indicated they had been using native species in their operation for 10 to 25 years. It is interesting to note that $21 \%$ of the respondents indicated that their main reason for using native plants was that native plants performed better than introduced species. Twenty four percent of the users indicated changing regulations and another $24 \%$ said a desire to increase biodiversity were their main reasons for using native plants. Other reasons cited are aesthetic value, conservation of the natural ecosystem, or less invasive when compared to forage species. An equal number of respondents also do not use native species for a number of reasons, including: high cost of seeds, lack of available of species, lack of quality, lack of information, or not requested by government regulatory agencies. 
Most of the plant materials purchased were used in the Great Plains (55\%) and the Grassland (37\%). Opinions varied widely among both producers and users about the type of plant material preferred, whether it is a cultivar, ecovar or wild harvested seeds.

Based on statistical analysis for the acceptance of cultivar, ecovar, and wild harvested seed as sources of native plant material, no significant differences $(p>0.05)$ were observed. However, both producers and users have indicated greater inclination towards plant material that has been performance tested. The users want plant material that has been tested for geographic adaptation, vigour and growth whereas the seed growers also wanted seed production information. Another interesting comment was that harvesting from native landscapes should be restricted or even be prohibited.

Sixty nine percent of the respondents were aware of the original genetic source of the materials they purchased. Thirty one percent did not have any information on the original genetic source of their plant materials. Three quarters of the respondents received information such as seed germination and purity, and source of seed from the producer.

Among the users of native plants, the horticulture industry represents $20 \%$, landscaping $17 \%$, wildlife habitat mitigation $9 \%$, medicinal $6 \%$, wetland restoration $9 \%$, landfills $3 \%$, agriculture $6 \%$, prairie restoration $6 \%$, and reclamation $24 \%$. Reclamation is further divided into oil \& gas (14\%), sand \& gravel (2\%), railways \& roadways ( $2 \%)$, and mines $(6 \%)$. There are differences between the values reported by the producers and users of native plants. This shows that the producers were selling their plant materials to users other than those who participated in this survey.

The total amount of money spent on the purchase of native grasses during 1997, 1998 and 1999 was $\$ 104,144$. Only 4 users $(n=22)$ provided expenditures on native plant materials. Nevertheless, over 47 species are being used, indicating great diversity. Forecasted use of native species looks encouraging. For example, average ( 9 users responded) number of plants used in year 2000 is approximately 57,000 . That number increases to approximately 63,000 plants by the year 2001. Some users indicated that they were not able to provide information on the 
amount spent and quantity of materials purchased as these are handled by a number of individuals within a company, (including contract personnel) and most of the time, no one keeps a record of that information.

\section{Recommendations for Future Actions}

To ensure success of the native plant industry, the following concerns by the producers and users of native plants should be addressed.

1. Lead time to set up a production plan. Customers need to understand that a substantial amount of time is needed to plan production of many species. Native species usually do not produce a seed crop in the year of establishment. As a result, native plant users should give at least a year's notice, to allow the grower to plan production of any particular species. Some growers suggest 1 to 2 years lead time for contract growing and, in some cases at least 5 years. The latter would mostly apply to shrubs and trees where the users require a certain size girth.

2. Labour intensive. Working with some species can be quite labor intensive and uncertain markets make it a risky venture.

3. Herbicides. Information is lacking on appropriate use of herbicides.

4. Experienced staff. It is difficult to find staff knowledgeable about native plants.

5. Lack of information. A lack of written material or methods on growing, propagation, seed harvesting, germination, cleaning, etc of native seeds hinders the market.

6. Contract growing. Growing under contract will help guarantee a market for the product. Sometimes producers cannot get a contract because their crop is not assured. In other cases producers cannot find markets for plants already grown. 
7. Lack of government support. Strong government competition in the United States (e.g., Conservation Reserve Program) makes it hard for local producers to compete. In Manitoba, there is a significant lack of government support for the use of local native species.

8. Research funding. More funds should be allocated to research and development. For example, research on seed production and plant performance in various regions. To ensure success in the market place, seed production ability should be the focus of new selections. Some species are sporadic in their seed production. The plants grow really well one year, then very poorly the next year. For example, American vetch. More research on native species with agricultural potential should also be conducted. (This would help to diversity markets for native plant materials.) There is a need to provide more information on ecovar and cultivar development. Other research area includes weed control. For example, an oil \& gas company is interested in maintaining bio-diversity and is currently using native species in revegetating oil wellsites. Their main problem is controlling weeds, which can increase the cost of reclamation.

9. Regulation. There is a need for definite reclamation guidelines. This will boost the use of native species. One company suggested that they will be willing to use native seed, but instead use a forestry mix, which is cheaper. The requirement for native species needs to come from government regulators before industry would be motivated to use expensive, less available native species. The native plant guidelines within Alberta need to be re-evaluated and the evaluation has to be conducted on an eco-site level. Another user of native plants suggested that wild harvesting should be regulated or even outlawed, except for some seed harvesting, but no plants should be removed from native prairie.

10. Need to educate the public. There is a lack of public education on the benefits of native plants and a general apathy about the importance of the need to use native species. There is a need to get the public on side. There is also a need to provide end 
users, the public and government bureaucrats with valid, updated information on benefits of native plants. There seemed to be confusion over the use of the word "native". One participant described it as "a label without reference to native to any particular ecoregion". For example, an ecotype collected and reared very far away may be acceptable while a local species from across some imaginary line is not considered native.

11. Availability of seed. Demand from contractors, designers, consultants, etc. far outstrips supply. One user has been using locally collected seed for rearing and planting of woody plants for more than 20 years and it is only recently that they have found it necessary to acquire native grass and legume seed. As yet they have not been able to acquire native legume seed in sufficient quantities for their use. They indicated that it would have been desirable if the logistics of seed supply had been worked out prior to regulatory imperatives respecting native seed use. The user best describes it by stating "the inability to sow legumes is a step backward in the science of reclamation and neither are the logistics in place for providing native/local seed of dependable purity and performance".

12. Cost. Because seed sources are scarce, costs are high when compared to agronomic species. Several growers raised this concern. If price and availability of desired species were more reasonable, more users would use native species.

"Note. The Native Plant Revegetation Guidelines for Alberta defined the word "native" on the basis of Natural Regions and Subregions. 
13. Quality control. There are few sources of good quality seed. Limited availability of clean seed for reclamation was identified as a significant issue. The requirement for reliable seed quality sources will grow as markets develop. Good quality seed will give the industry a good image.

14. Cost of seed testing. Seed testing is expensive, especially for limited quantities of seed.

15. Capital investment. It takes a huge capital investment to get into the native plant business. High overhead, high cost of equipment and high cost of production of some species hinders the industry. It seems that it is a specialized industry and there is not a harvesting machine that works on a variety of crops. As a result it can lead to higher costs of seed.

16. Processing. Certain species, e.g., Stipa are difficult to process. Weather conditions can have an adverse impact on production. Seed harvest and cleaning are very slow processes. For example, to produce $4 \mathrm{~kg}$ of cleaned forb seed in 1998 required approximately $30 \%$ of one person's work time. The oil and gas industry currently uses native grasses for reclamation, but would like to use more forbs wherever possible.

17. Marketing. Information is needed on how to find a market for the plant materials one is growing.

18. Honest marketing. Seed companies with proprietary claims to cultivars are not making these cultivars readily available to small producers. Also, other producers do not compete fairly (unethical, selling "natives" or "wildflowers" from United States) and that hinders the market.

19. Competition. It is a very competitive business. Development of native varieties takes years, only to be undone in one year of planting by another seed grower. 
This is a very secretive industry. Suppliers and producers of native plant species are somewhat hesitant to provide information for fear of competition from other producers and suppliers. However based on the information received, the native plant industry seems to be very diverse and growing.

\section{References}

1. Alberta Native Plant Council. 1998. Native Plant Source List and Collection and Use Guidelines. Edmonton, Alberta.

2. Gerling, H.S., M.G. Willoughby, A. Schoepf, K.E. Tannas and C.A. Tannas. 1996. A Guide to Using Native Plants on Disturbed Lands. Alberta Agriculture, Food and Rural Development and Alberta Environmental Protection. 247pp.

3. Market Assessment of Native Plant Materials in Saskatchewan. 1997. Prepared by Native Plant Society of Saskatchewan and Northwest Saskatchewan Grasslands Association. 51pp.

4. Minnesota State Department of Agriculture. 1993. Native plant survey. Minnesota, USA. 42pp.

5. Moss, E.H. 1983. Flora of Alberta. $2^{\text {nd }}$ Edition revised by J.G. Packer. University of Toronto Press. $687 \mathrm{pp}$.

6. Native Plant Working Group. 1999. Draft native plant revegetation guidelines for Alberta. H.S. Gerling (ed.), Alberta Agriculture, Food and Rural Development. Edmonton, Alberta.

7. Zar, J.H. 1984. Biostatistical Analysis, Second Edition, Prentice-Hall, New Jersey. 718pp.

8. Map of Ecoregions of North America.

http://www.cprc.uregina.ca/ccea/ecozones/levell.html

9. Map of Natural regions of Alberta. http://www.gov.ab.ca/env/parks/anhic/anhic.html 
APPENDIX 1 - Species harvested in the wild, by amounts and by ecoregion.

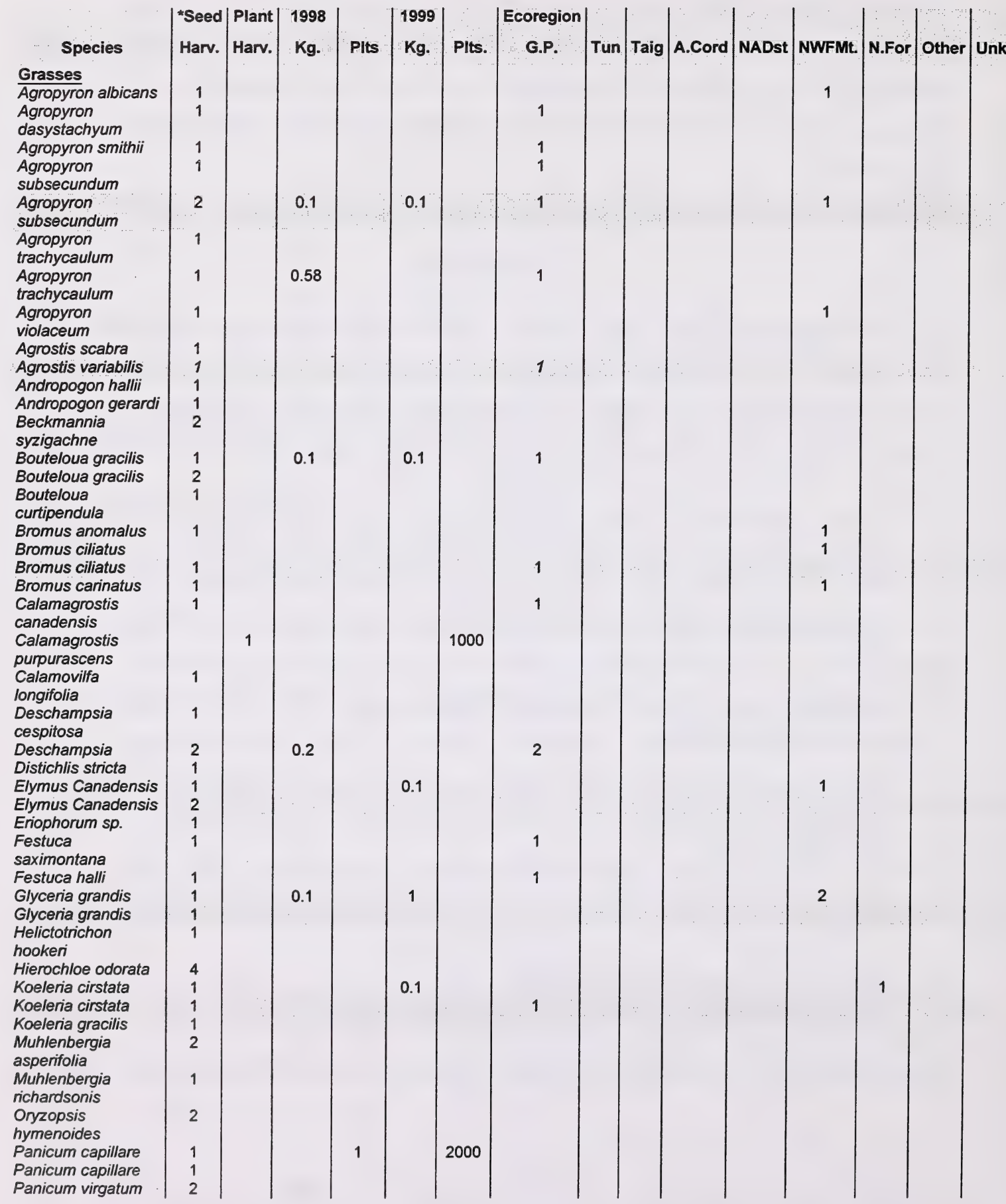

*Note. Numbers in first two columns indicate the number of responses received for each species harvested, but in many cases, neither the amount of seed or plants, nor the ecoregion were reported 


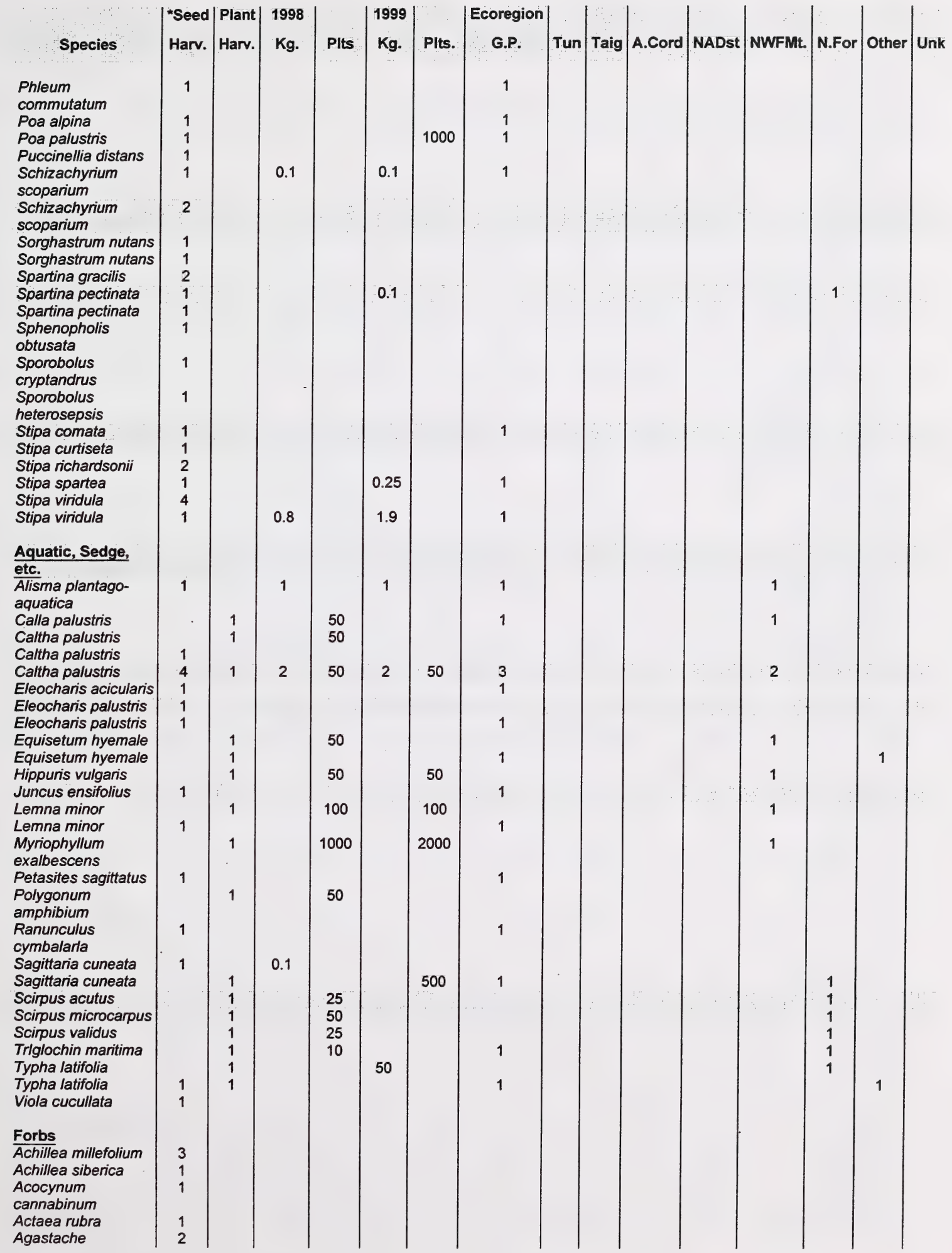




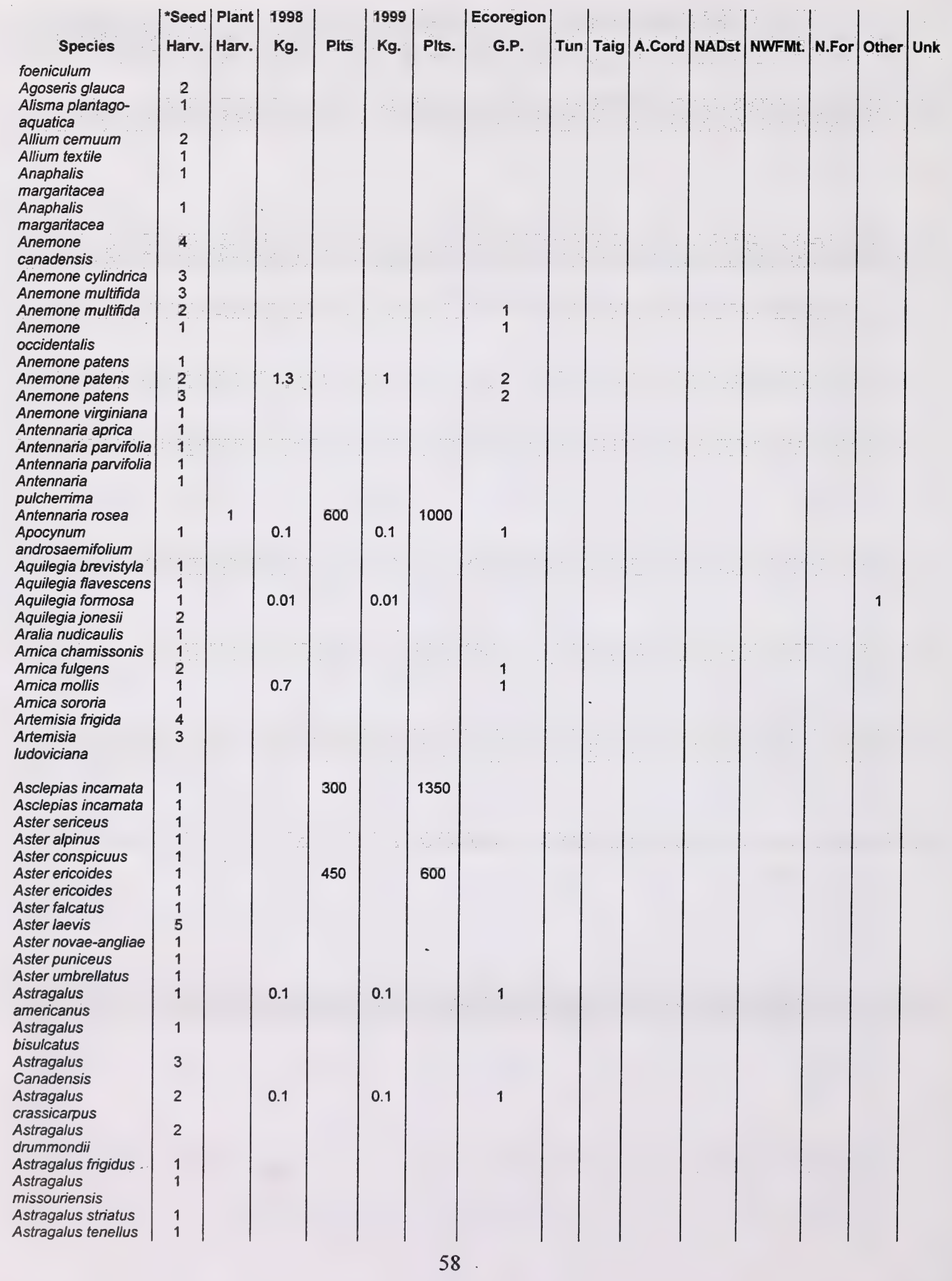




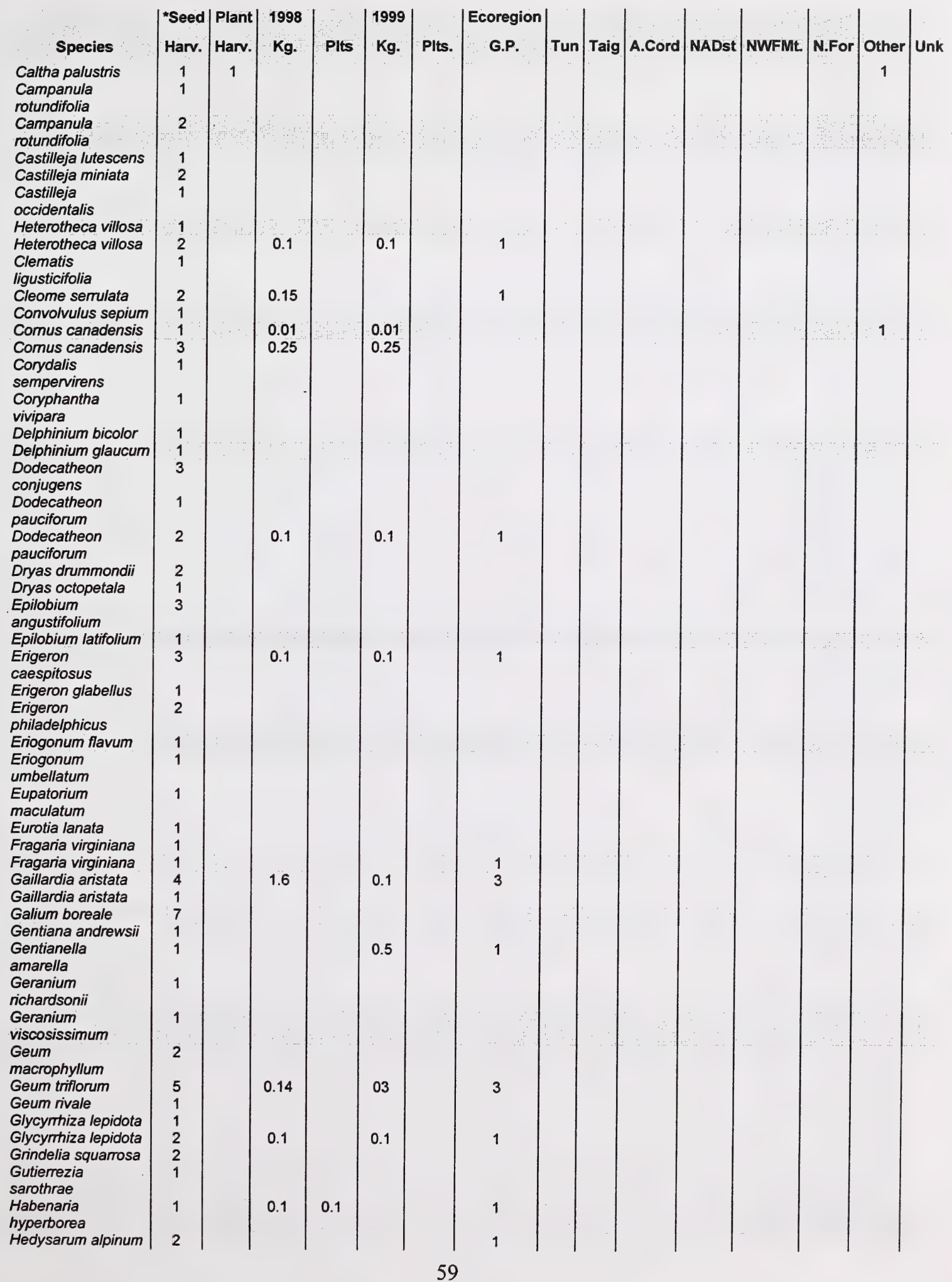




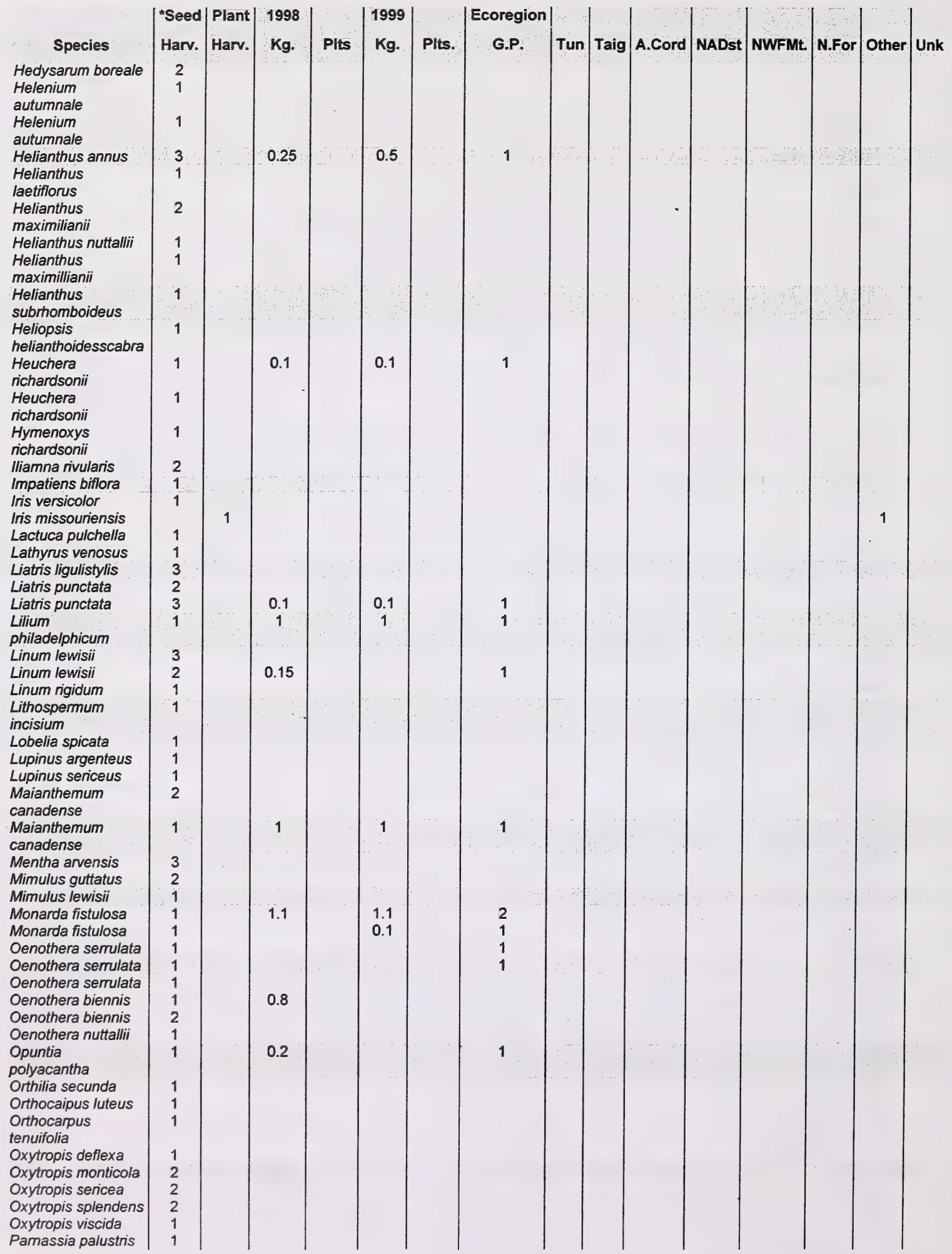




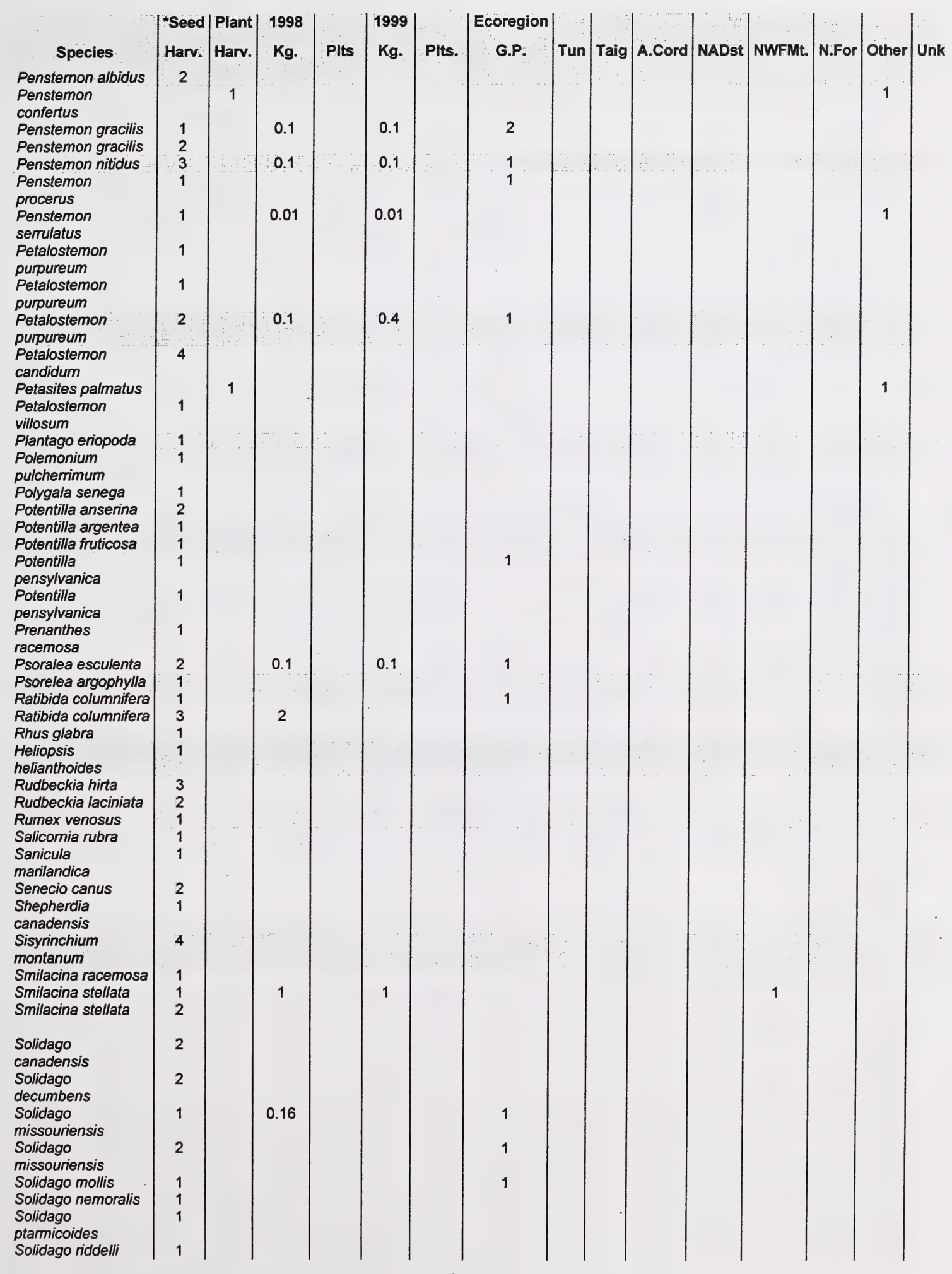




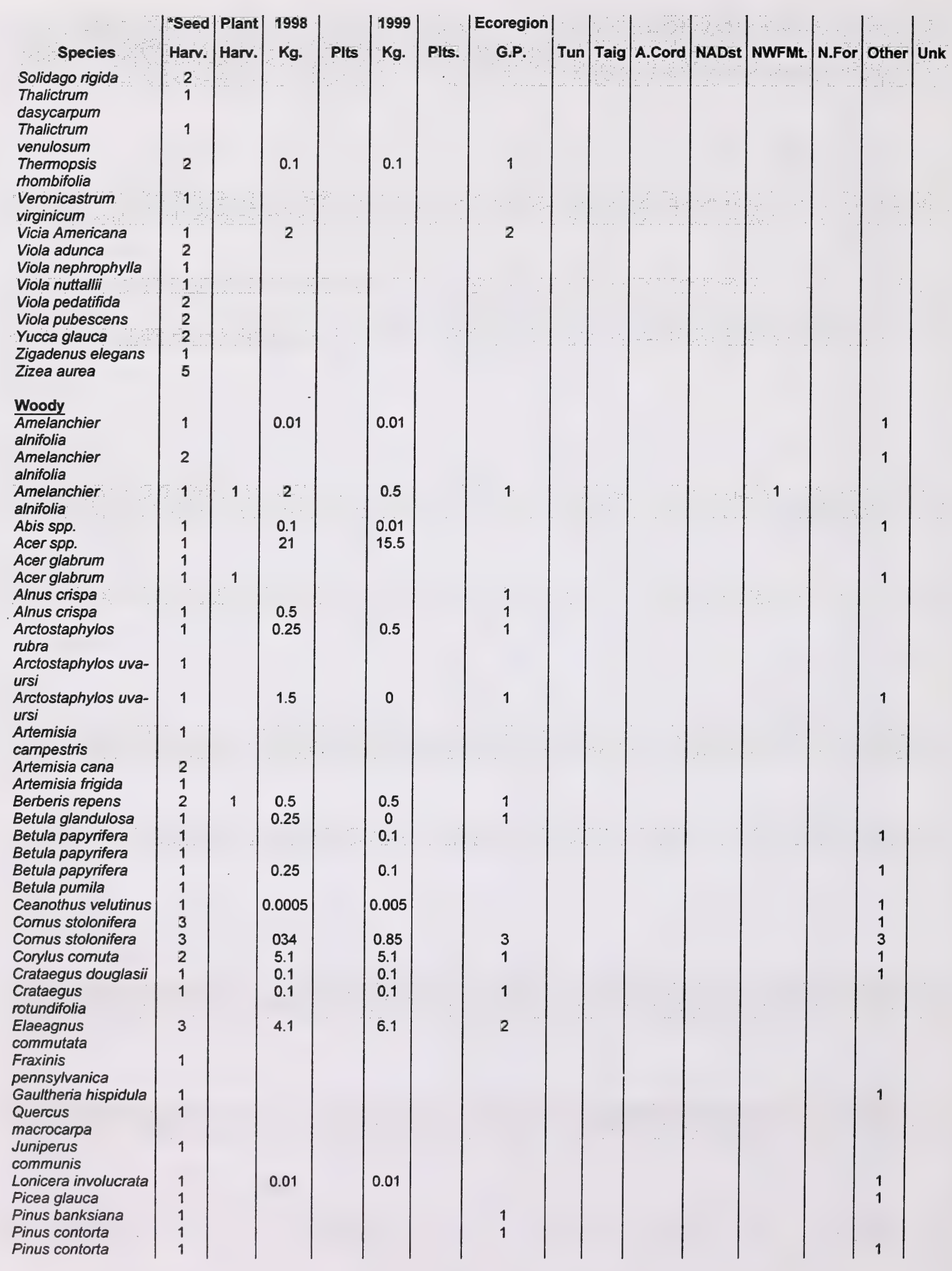




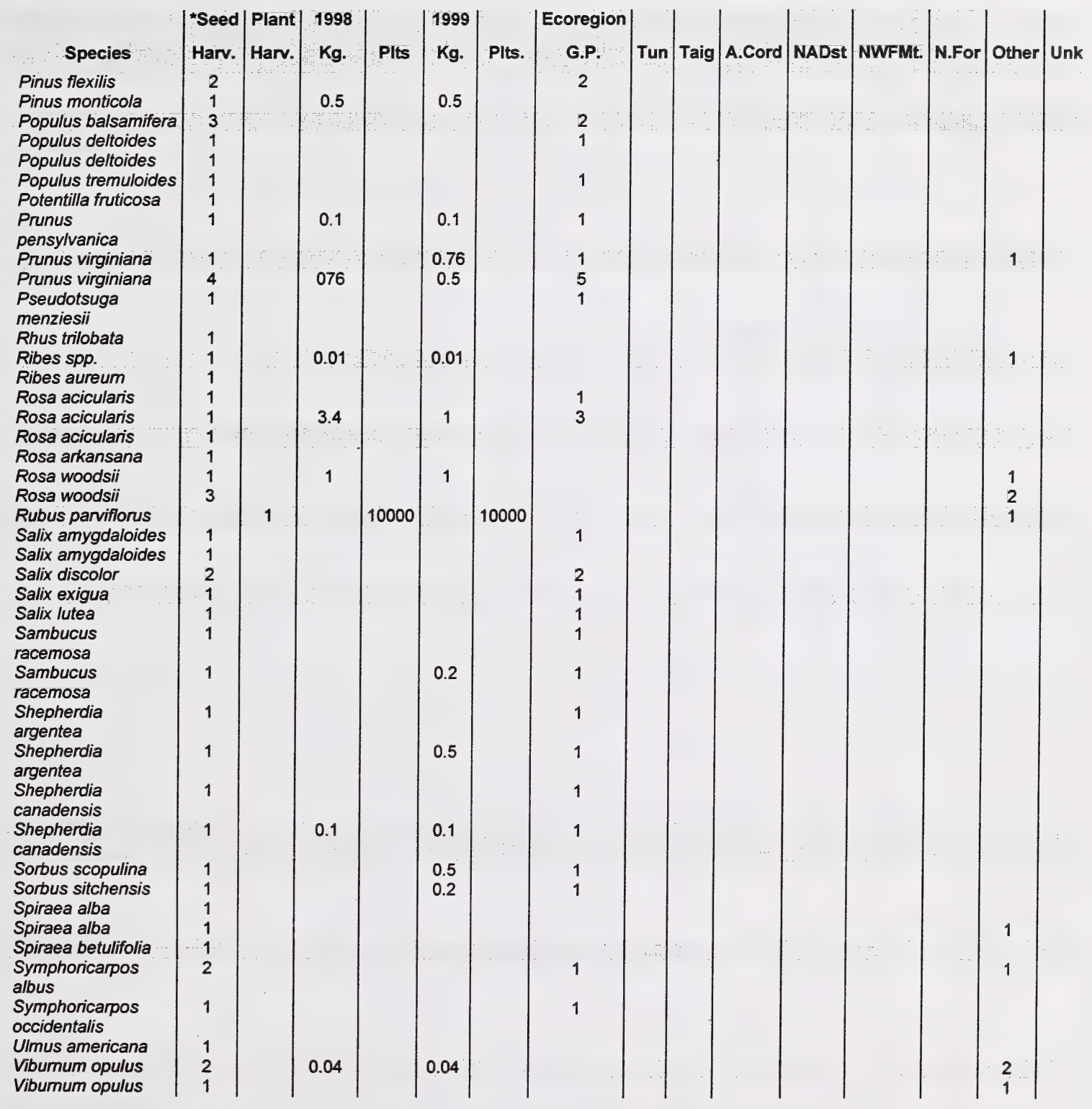




\begin{tabular}{|c|c|c|c|c|c|c|c|c|c|c|c|c|c|c|c|}
\hline Species & $\begin{array}{l}\text { *Seed } \\
\text { Harv. }\end{array}$ & Plant & $\begin{array}{c}1998 \\
\mathrm{Kg} .\end{array}$ & Plts & $\begin{array}{c}1999 \\
\mathrm{Kg} .\end{array}$ & PIts. & \begin{tabular}{|c} 
Ecoregion \\
G.P.
\end{tabular} & Tun & Taig & A.Cord & NADst & NWFMt. & N.For & Other & Unk \\
\hline $\begin{array}{l}275 \text { Various } \\
\text { species } \\
\text { Too many to list } \\
\text { species }^{\mathbb{}}\end{array}$ & $\begin{array}{l}1 \\
1\end{array}$ & & 50 & & 50 & & & & & & & 1 & & 1 & \\
\hline
\end{tabular}

Note. "The producer did not wish to provide details on the number and amount of species collected from native landscapes.

G.P. $=$ Great Plains

Tun $=$ Tundra

Taig $=$ Taiga

A.cord $=$ Arctic Cordillera

NADst $=$ North American Deserts

NWFMt. $=$ Northwestern Forest Mountains

N.for $=$ Northern Forests 
APPENDIX 2 - Amount and origin of plant materials sold in 1998 and 1999.

\begin{tabular}{|c|c|c|c|c|c|c|c|c|c|c|c|c|c|}
\hline & \multicolumn{2}{|c|}{1998} & \multicolumn{2}{|c|}{1999} & \multicolumn{9}{|c|}{ Ecoregion } \\
\hline Species & $\mathrm{Kg}$. & \#Plts & $\mathrm{Kg}$. & \# PIts & G.P. & Tun & Taig & A.Cord & NADst & NWFMt. & N.For & Other & Un \\
\hline Grasses & & & & & & & & & & & & & \\
\hline Agropyron albicans & & & 28550 & & & & & & & 1 & & & \\
\hline Agropyron dasystachyum & 40000 & & 40000 & & & & & & & & & & \\
\hline Agropyron dasystachyum & 15000 & 350 & 70000 & 1100 & 1 & & & & & & & & \\
\hline Agropyron riparium & 30000 & & 30000 & & & & & & & & & & \\
\hline Agropyron smithii & 40000 & & 40000 & & & & & & & & & & \\
\hline Agropyron smithii & 10000 & & 5000 & & 1 & & & & & & & & \\
\hline Agropyron subsecundum & 2200 & & 1950 & & 1 & & & & & 1 & & & \\
\hline Agropyron trachycaulum & 50000 & & 50000 & & & & & & & & & & \\
\hline Agropyron trachycaulum & & & 0.1 & & 1 & & & & & & & & \\
\hline Agropyron violaceum & 700 & & 700 & & & & & & & 1 & & & \\
\hline Agrostis scabra & & $\cdot$ & & 600 & & & & & & & & & \\
\hline Agrostis variablilis & 35000 & & 50000 & & 1 & & & & & & & & \\
\hline Bouteloua gracilis & 300 & & 25 & & & & & & & & & & \\
\hline Bouteloua gracilis & & 100 & & 200 & 1 & & & & & & & & \\
\hline Bromus anomalus & 500 & & & & & & & & & 1 & & & \\
\hline Bromus carinatus & 10300 & & 10700 & & & & & & & & & & \\
\hline Bromus ciliatus & 2700 & & 3250 & & & & & & & & & & \\
\hline Bromus ciliatus & & & 800 & & 1 & & & & & & & & \\
\hline Calamagrostis canadensis & & & 50 & & 1 & & & & & & & & \\
\hline Deschampsia cespitosa & 7000 & & 5000 & & 1 & & & & & & & & \\
\hline Deschampsia cespitosa & 1000 & & 1000 & & & & & & & & & & \\
\hline Deschampsia cespitosa & & 300 & 0.1 & 750 & 1 & & & & & & & & \\
\hline Distichlis stricta & 5000 & & 5000 & & & & & & & & & & \\
\hline Elymus canadensis & 5000 & & 5000 & & & & & & & 1 & & & \\
\hline Elymus canadensis & 200 & 300 & & 100 & & & & & & & & & \\
\hline Festuca halli & 10000 & & 10000 & & & & & & & & & & \\
\hline Festuca halli & 0.1 & 20 & 0.1 & & 1 & & & & & 2 & & & \\
\hline Festuca saximontana & 1500 & 600 & & & 1 & & & & & & & & \\
\hline Hierochloe odorata & & 300 & & 700 & & & & & & $\therefore$ & & & \\
\hline Koelenia cirstata & 5000 & & 5000 & & & & & & & & 1 & & \\
\hline Koeleria cirstata & 1500 & & 4000 & & 1 & & & & & & & & \\
\hline Koeleria gracilis & & 400 & & 500 & & & & & & & & & \\
\hline Oryzopsis hymenoides & 1000 & & 1000 & & & & & & & & & & \\
\hline \multicolumn{14}{|l|}{ Oryzopsis hymenoides } \\
\hline Panicum capillare & 10000 & & 10000 & & & & & & & & & & \\
\hline Panicum virgatum & & 100 & & 1100 & & & & & & & & & \\
\hline Phleum commutatum & & & 25 & & 1 & & & & & & & & \\
\hline Poa alpina & 10000 & & 13000 & & 1 & & & & & & & & \\
\hline Poa alpina & 500 & & 100 & & & & & & & & & & \\
\hline Poa palustris & 5000 & & 5000 & & & & & & & & & & \\
\hline Poa palustris & & & 2000 & & 1 & & & & & & & & \\
\hline Schizachyrium scoparium & & 560 & & 1400 & 1 & & & & & & & & \\
\hline
\end{tabular}

Note. Some species are repeated more than once as in some cases neither the amount of seed or plants sold, nor the ecoregion were reported. 


\begin{tabular}{|c|c|c|c|c|c|c|c|c|c|c|c|c|}
\hline & & & & & & & & & Ecoregic & & & \\
\hline Species & $\mathrm{Kg}$. & \#PIts & $\mathrm{Kg}$. & \# Plts & G.P. & Tun & Taig & A.Cord & NADst & NWFMt. & N.For & \begin{tabular}{|l|} 
Other \\
\end{tabular} \\
\hline Sorghastrum nutans & & 400 & & 700 & & & & & & & & \\
\hline Spartina gracilis & & & & 50 & & & & & & & 1 & \\
\hline Sphenopholis obtusata & & & & 750 & & & & & & & & \\
\hline Sporobolus heterolsepsis & & 200 & & 800 & & & & & & & & \\
\hline Stipa comata & 50 & & 25 & & & & & & & & & \\
\hline Stipa comata & & & 250 & & 1 & & & & & & & \\
\hline Stipa spartea & & & & $\ldots$ & 1. & & & & & & & \\
\hline Stipa viridula & & 300 & & 1200 & & & & & & & & \\
\hline Stipa viridula & & & & & 1 & & & & & & & \\
\hline & & & & & & & & & & & & \\
\hline Aquatics, Sedge, etc. & & & & & & & & & & & & \\
\hline Alisma plantago-aquatica & & 250 & & 300 & 1 & & & & & 1 & & \\
\hline Calla palustris & $\therefore$ & & & 150 & 1 & & & & & 1 & & \\
\hline Caltha palustris & & 400 & & 400 & 1 & & & & & 1 & & \\
\hline Caltha palustris & & 150 & & 250 & 1 & & & & & & & \\
\hline Carex aquatilis & & 50 & & 250 & 1 & & & & & 1 & & \\
\hline Eleocharis acicularis & & & & 100 & 1 & & & & & & & \\
\hline Eleocharis palustris & & 150 & & 200 & 1 & & & & & & & \\
\hline Eleocharis palustris & & & & & & & & & & & & \\
\hline Equisetum hyemale & & 100 & & 200 & 1 & & & & & & & 1 \\
\hline Equisetum hyemale & & & & & & & & & & 1 & & \\
\hline Juncus ensifolius & & 300 & & 300 & 1 & & & & & & & \\
\hline Lemna minor & & & & & & & & & & 1 & & \\
\hline Mentha arvensis & & & & & & & & & & & & \\
\hline Petasites sagittatus & & 100 & & 150 & 1 & & & & & & & \\
\hline Ranunculus cymbalarla & & 100 & & 150 & 1 & & & & & & & \\
\hline Sagittaria cuneata & 0.1 & & & & & & & & & & & \\
\hline Typha latifolia & & 200 & & 250 & 1 & & & & & & 1 & 1 \\
\hline Typha latifolia & & & & & & & & & & & 1 & \\
\hline & & & & & & & & & & & & \\
\hline Forbs & & & & & & & & & & & & \\
\hline Achillea millefolium & & & & & & & & & & & & \\
\hline Actaea rubra & 1 & 300 & & 500 & & & & & & & & \\
\hline Agastache foeniculum & & 300 & & 500 & & & & & & & & \\
\hline Allium stellatum & & 50 & & 20 & & & & & & & & \\
\hline Anaphalis margaritacea & & 250 & & 300 & & & & & & & & \\
\hline Anemone canadensis & & 200 & & 100 & & & & & & & & \\
\hline Anemone multifida & & 450 & & 500 & & & & & & & & \\
\hline Anemone multifida & 0.25 & & & 3 & 1 & & & & & & & \\
\hline Anemone multifida & & & & & & & & & & & & \\
\hline Anemone occidentalis & & & 0.25 & & 1 & & & & & & & \\
\hline Anemone patens & 0.3 & 1200 & & 1200 & & & & & & & & \\
\hline Anemone patens & & & & & 1 & & & & & & & \\
\hline Anemone patens & & & 0.1 & & 1 & & & & & & & \\
\hline Anemone patens & 0.1 & & 0.1 & & 1 & & & & & & & \\
\hline Antennaria parvifolia & 0.82 & 600 & & 900 & & & & & & & & \\
\hline Antennaria rosea & & 600 & & 1000 & & & & & & & & \\
\hline
\end{tabular}




\begin{tabular}{|c|c|c|c|c|c|c|c|c|c|c|c|c|c|}
\hline & \multicolumn{2}{|c|}{1998} & \multicolumn{2}{|c|}{1999} & \multicolumn{9}{|c|}{ Ecoregion } \\
\hline Species & $\mathrm{Kg}$. & \#PIts & $\mathrm{Kg}$. & \# Plts & G.P. & Tun & Taig & A.Cord & NADst & NWFMt. & N.For & \begin{tabular}{|l|} 
Other \\
\end{tabular} & $\overline{U n}$ \\
\hline Aquilegia canadensis & & 300 & & 300 & & & & & & & & & \\
\hline Amica fulgens & & & & & 1 & & & & & & & & \\
\hline Amica mollis & 0.46 & & & & 1 & & & & & & & & \\
\hline Artemisia frigida & & 200 & & 500 & & & & & & & & & \\
\hline Artemisia ludoviciana & & 400 & & 700 & & & & & & & & & \\
\hline Aster alpinus & & 600 & & 800 & & & & & & & & & \\
\hline Aster laevis & & 750 & & 450 & & & & & & & & & \\
\hline Astragalus americanus & & & & & 1 & & & & & & & & \\
\hline Astragalus crassicaipus & & & & & 1 & & & & & & & & \\
\hline Caltha palustris & & 2000 & & 2000 & & & & & & & & & \\
\hline Campanula rotundifolia & & 300 & & 400 & & & & & & & & & \\
\hline \multicolumn{14}{|l|}{ Clematis ligusticifolia } \\
\hline Cleome semulata & & 0.1 & & & 1 & & & & & & & & \\
\hline Corydalis sempervirens & 0.15 & 50 & & 50 & & & & & & & & & \\
\hline Dodecatheon pauciforum & & 200 & & 250 & & & & & & & & & \\
\hline Dodecatheon pauciforum & & & 0.1 & & 1 & & & & & & & & \\
\hline Epilobium angustifolium & & 350 & & 500 & & & & & & & & & \\
\hline Erigeron caespitosus & & & & & 1 & & & & & & & & \\
\hline Erigeron philadelphicus & & 350 & & 600 & & & & & & & & & \\
\hline Eupatorium maculatum & & 700 & & 900 & & & & & & & & & \\
\hline \multicolumn{14}{|l|}{ Eurotia lanata } \\
\hline Fragaria virginiana & & 300 & & & 1 & & & & & & & & \\
\hline Fragaria virginiana & & 60 & & 60 & & & & & & & & & \\
\hline Gaillardia aristata & 0.1 & 600 & & 600 & & & & & & & & & \\
\hline Gaillardia aristata & & & & & 1 & & & & & & & & \\
\hline Gaillardia aristata & & & 0.4 & & 1 & & & & & & & & \\
\hline Gaillardia aristata & & & 1 & & 2 & & & & & & & & \\
\hline Galium boreale & 0.46 & 100 & & 100 & & & & & & & & & \\
\hline Gentianella amarella & & & & & 1 & & & & & & & & \\
\hline Geum triflorum & & 900 & & 1100 & 1 & & & & & & & & \\
\hline Geum triflorum & & & & 0.2 & 1 & & & & & & & & \\
\hline Glycymiziza lepidota & 0.14 & 100 & & 200 & & & & & & & & & \\
\hline Glycymniza lepidota & & & & $\cdots$ & 1 & & & & & & & & \\
\hline Habenaria hyperborea & & & & & 1 & & & & & & & & \\
\hline Hedysarum alpinum & & & 1 & & 1 & & & & & & & & \\
\hline Helenium autumnale & 0.33 & 50 & & & & & & & & & & & \\
\hline Helianthus annus & & & 1 & & 1 & & & & & & & & \\
\hline Helianthus maximillianii & & 200 & & 850 & & & & & & & & & \\
\hline $\begin{array}{l}\text { Heliopsis } \\
\text { helianthoidesscabra }\end{array}$ & & 800 & & 1000 & & & & & & & & & \\
\hline Heterotheca villosa & & & & & 1 & & & & & & & & \\
\hline Heuchera richardsonii & & 50 & & 125 & 1 & & & & & & & & \\
\hline Impatiens biflora & & 45 & & 60 & & & & & & & & & \\
\hline Ins versicolor & & 100 & & 1005 & & & & & & & & & \\
\hline \multicolumn{14}{|l|}{ Lathyrus venosus } \\
\hline Liatris ligulistylis & & 1000 & & 14500 & & & & & & & & & \\
\hline Liatris punctata & & 300 & & 300 & 1 & & & & & & & & \\
\hline Liatris punctata & & & 0.2 & & 1 & & & & & & & & \\
\hline
\end{tabular}




\begin{tabular}{|c|c|c|c|c|c|c|c|c|c|c|c|c|}
\hline & \multicolumn{2}{|c|}{1998} & \multicolumn{2}{|c|}{1999} & \multicolumn{8}{|c|}{ Ecoregion } \\
\hline Species & $\mathrm{Kg}$. & \#Plts & $\mathrm{Kg}$. & \# Plts & G.P. & Tun & Taig & A.Cord & NADst & NWFMt. & N.For & Other \\
\hline Lilium philadelphicum & 0.35 & & & 300 & 1 & & & & & & & \\
\hline$\underline{\text { Linum lewisii }}$ & & 500 & & 400 & & & & & & & & \\
\hline Oenothera serrulata & 0.8 & 150 & & 150 & 1 & & & & & & & \\
\hline Oenothera serrulata & & & & & 1 & & & & & & & \\
\hline Opuntia polyacantha & & & 0.35 & & 1 & & & & & & & \\
\hline Penstemon gracilis & 0.25 & 100 & & & & & & & & & & \\
\hline Penstemon gracilis & 0.2 & & 0.15 & & 2 & & & & & & & \\
\hline Penstemon procerus & & & 0.3 & & 1 & & & & & & & \\
\hline Petalostemon purpureum & 0.25 & 800 & & 1600 & & & & & & & & \\
\hline \multicolumn{13}{|l|}{ Petalostemon purpureum } \\
\hline Petalostemon purpureum & 2.1 & & 0.2 & & 1 & & & & & & & \\
\hline Petalostemon candidum & 3.75 & 300 & & 500 & & & & & & & & \\
\hline \multicolumn{13}{|l|}{ Petalostemon candidum } \\
\hline Potentilla pensylvanica & & $\cdot$ & 0.45 & & 1 & & & & & & & \\
\hline Ratibida columnifera & 1.6 & 750 & & 700 & & & & & & & & \\
\hline Ratibida columnifera & & 2 & & & & & & & & & & \\
\hline Ratibida columnifera & & & 2.8 & & 1 & & & & & & & \\
\hline Rudbeckia hira & & 1300 & & 1005 & & & & & & & & \\
\hline Rudbeckia laciniata & & 100 & & 200 & & & & & & & & \\
\hline \multicolumn{13}{|l|}{ Solidago missouriensis } \\
\hline Solidago missouriensis & 0.16 & & 0.1 & & 1 & & & & & & & \\
\hline Solidago mollis & 0.1 & & 0.1 & & 1 & & & & & & & \\
\hline Solidago rigida & & 300 & & 800 & & & & & & & & \\
\hline Thalictrum dasycarpum & & 100 & & 600 & & & & & & & & \\
\hline Vicia americana & & & 25 & & 2 & & & & & & & \\
\hline Viola adunca & 200 & 400 & & 300 & & & & & & & & \\
\hline Viola nephrophylla & & 100 & & 400 & & & & & & & & \\
\hline Viola pedatifilda & & 300 & & 150 & & & & & & & & \\
\hline Viola pubescens & & 200 & & 400 & & & & & & & & \\
\hline Zizea aurea & & 300 & & 350 & & & & & & & & \\
\hline Zizia aptera & & 450 & & 550 & & & & & & & & \\
\hline & & & & & & & & & & & & \\
\hline \multicolumn{13}{|l|}{ Woody } \\
\hline Acer glabrum & & 1000 & & & & & & & & & & \\
\hline Acer glabrum & & 1000 & & 1500 & & & & & & & & 1 \\
\hline Alnus crispa & & 11000 & & 11000 & 1 & & & & & & & \\
\hline Amelanchier alnifolia & & 10000 & & & & & & & & & & \\
\hline Amelanchier alnifolia & & 3000 & & 5000 & & & & & & & & \\
\hline Amelanchier alnifolia & & 250 & & 500 & & & & & & & & 1 \\
\hline Arctostaphylos uva-ursi & & 10000 & & 10000 & 1 & & & & & & & 1 \\
\hline Arctostaphylos uva-ursi & & 1000 & & 10000 & & & & & & & & \\
\hline Betula nana & & 0 & & 50 & $\therefore$ & & & & & & & 1 \\
\hline Betula papyrifera & & 100 & & 100 & & & & & & & & 1 \\
\hline Ceanothus velutinus & & 1000 & & & & & & & & & & \\
\hline Clematis occidentalis & & & 1 & & & & & & & & & \\
\hline Comus stolonifera & 0 & 1000 & 6500 & & & & & & & & & \\
\hline Comus stolonifera & & 25000 & & & & & & & & & & 1 \\
\hline Comus stolonifera & & 10000 & & 10000 & & & & & & & & \\
\hline
\end{tabular}




\begin{tabular}{|c|c|c|c|c|c|c|c|c|c|c|c|c|c|}
\hline & \multicolumn{2}{|c|}{1998} & \multicolumn{2}{|c|}{1999} & \multicolumn{9}{|c|}{ Ecoregion } \\
\hline Species & $\mathrm{Kg}$. & \#Plts & $\mathrm{Kg}$. & \# Plts & G.P. & Tun & Taig & A.Cord & NADst & NWFMt. & N.For & Other & Un \\
\hline Comus stolonifera & & 100 & & 300 & & & & & & & & 1 & \\
\hline Comus stolonifera & & & & 60 & 2 & & & & & & & 1 & \\
\hline Corylus comuta & & 300 & & & 1 & & & & & & & & \\
\hline Crataegus douglasii & & 1000 & & 1000 & & & & & & & & 1 & \\
\hline Elaeagnus commutata & & 1000 & & 1000 & & & & & & & & & \\
\hline Elaeagnus commutata & & 1000 & & & 1 & & & & & & & & \\
\hline Philadelphus lewisii & & 2000 & & & & & & & & & & & \\
\hline Philadelphus lewisii & & 50 & & 250 & & & & & & & & 1 & \\
\hline Physocarpus malvaceus & & & & 150 & & & & & & & & 1 & \\
\hline Picea glauca & & 200000 & & 340000 & & & & & & & & & \\
\hline Picea glauca & & 1000 & & 1000 & & & & & & & & 1 & \\
\hline Pinus banksiana & & 8000 & & 31000 & 1 & & & & & & & & \\
\hline Pinus contorta & & 36000 & & 37000 & 1 & & & & & & & & \\
\hline Pinus contorta & & 1000 & & 1000 & & & & & & & & 1 & \\
\hline Pinus flexilis & & 1000 & & 1000 & 1 & & & & & & & & \\
\hline Populus balsamifera & & 15000 & & 15000 & 1 & & & & & & & & \\
\hline Populus balsamifera & & & & 100 & 1 & & & & & & & & \\
\hline Populus deltoides & & 5110 & & 10000 & 1 & & & & & & & & \\
\hline Populus tremuloides & & 25000 & & 2500 & 1 & & & & & & & & \\
\hline Populus tremuloides & & 10000 & & & & & & & & & & & \\
\hline Populus tremuloides & & & & 40 & 1 & & & & & & & & \\
\hline Prunus virginiana & 0.27 & 1000 & & 1000 & 1 & & & & & & & 1 & \\
\hline Prunus virginiana & & 8600 & & 8600 & 1 & & & & & & & & \\
\hline Prunus virginiana & & & 0.27 & & 2 & & & & & & & & \\
\hline Pseudotsuga menziesii & & 1000 & & 1000 & 1 & & & & & & & & \\
\hline Rosa acicularis & 0.4 & & & & 1 & & & & & & & & \\
\hline Rosa acicularis & & 15000 & & 15000 & 1 & & & & & & & & \\
\hline Rosa acicularis & & & 0.1 & & 2 & & & & & & & & \\
\hline Rosa acicularis & & & & 100 & & & & & & & & & \\
\hline \multicolumn{14}{|l|}{ Rosa acicularis } \\
\hline Rosa arkansana & & 100 & 200 & 200 & & & & & & & & & \\
\hline Rosa woodsii & & 10000 & & 10000 & & & & & & & & 1 & \\
\hline Rosa woodsii & & 1000 & & & & & & & & & & & \\
\hline Rosa woodsii & & 200 & & 200 & & & & & & & & 1 & \\
\hline Salix amygdaloides & & 4000 & & 4000 & 1 & & & & & & & & \\
\hline Salix discolor & & 4000 & & 4000 & 1 & & & & & & & & \\
\hline Salix discolor & & 1000 & & 1000 & & & & & & & & & \\
\hline Salix discolor & & & & 20 & 1 & & & & & & & 1 & \\
\hline Salix discolor & & & & 50 & 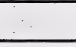 & & & & & & & 1 & \\
\hline Salix exigua & & 11000 & & 11000 & 1 & & & & & & & & \\
\hline Salix lutea & & 1000 & & 1000 & 1 & & & & & & & & \\
\hline Sambucus racemosa & & 2300 & & 2300 & 1 & & & & & & & & \\
\hline Sambucus racemosa & & 1000 & & 1000 & & & & & & & & 1 & \\
\hline Sambucus racemosa & & 500 & & & 1 & & & & & & & & \\
\hline Shepherdia argentea & & 6000 & & 6000 & 1 & & & & & & & & \\
\hline Shepherdia canadensis & & 1000 & & 1000 & 1 & & & & & & & & \\
\hline Spiraea alba & & & & 100 & & & & & & & & & \\
\hline
\end{tabular}




\begin{tabular}{|c|c|c|c|c|c|c|c|c|c|c|c|c|}
\hline & \multicolumn{2}{|c|}{1998} & \multicolumn{2}{|c|}{1999} & \multicolumn{8}{|c|}{ Ecoregion } \\
\hline Species & $\mathrm{Kg}$. & \#Plts & $\mathrm{Kg}$. & \# Plts & G.P. & Tun & Taig & A.Cord & NADst & NWFMt. & N.For & Other \\
\hline Symphoricarpos albus & & 1000 & & 1000 & 1 & & & & & & & \\
\hline Symphoricarpos albus & & 1000 & & 1000 & 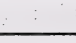 & & & & & & & \\
\hline Symphoricarpos albus & & 500 & & & & & & & & & & 1 \\
\hline Symphoricarpos albus & & 50 & & 700 & & & & & & & & 1 \\
\hline Symphoricarpos occidentalis & & & & 100 & 1 & & & & & & & \\
\hline Vaccinium myrtilloides & & 1000 & & 5000 & & & & & & & & \\
\hline Vaccinium vitis-idaea & & 1000 & & 1000 & & & & & - & . & & 1 \\
\hline Virbumum opulus & & 1000 & & 1000 & & & & & & & & 1 \\
\hline Virburmum opulus & & & & 100 & & & & & & & & 1 \\
\hline 275 Various species $\pi$ & & 250,000 & & & & & & & & & & 1 \\
\hline Too many to list species & & 125,000 & & 150,000 & & & & & & 1 & & \\
\hline
\end{tabular}

Note. "No further details were provided by the producers.

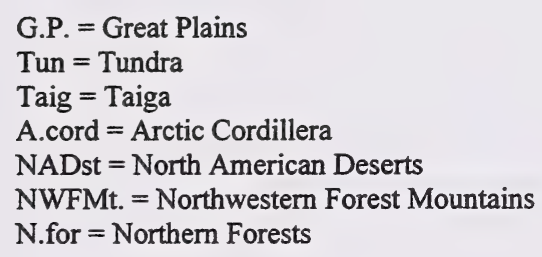


APPENDIX 3 - Longterm forecast of native plant production.

\begin{tabular}{|c|c|c|c|c|c|c|}
\hline \multirow{3}{*}{ Species } & \multicolumn{6}{|c|}{ Long-term production } \\
\hline & \multicolumn{2}{|c|}{2000} & \multicolumn{2}{|c|}{2002} & \multicolumn{2}{|c|}{2005} \\
\hline & $\mathrm{Kg}$. & \# Plts. & $\mathrm{Kg}$. & \# Plts. & 2005 & \# Plts. \\
\hline \multicolumn{7}{|l|}{ Grasses } \\
\hline Agropyron dasystachyum & 5000 & & 10000 & & 10000 & \\
\hline \multicolumn{7}{|l|}{ Agropyron dasystachyum } \\
\hline Agropyron smithii & 10000 & & 10000 & & 10000 & \\
\hline Agropyron subsecundum & 10700 & & 20000 & & 16000 & \\
\hline Agropyron riparium & 6800 & & 13000 & & 13000 & \\
\hline Agropyron trachycaulum & 76000 & & 90000 & & 80000 & \\
\hline Agropyron violaceum & 1500 & & 1500 & & 5000 & \\
\hline \multicolumn{7}{|l|}{ Andropogon gerardi } \\
\hline Beckmannia syzigachne & 1 & & & & & \\
\hline \multicolumn{7}{|l|}{ 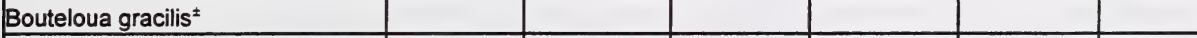 } \\
\hline Bouteloua gracilis & 200 & & 200 & & 200 & \\
\hline Bromus anomalus & & & 1000 & & 2000 & \\
\hline Bromus ciliatus & 5000 & & 5000 & & 5000 & \\
\hline Bromus carinatus & 3000 & & 6000 & & 6000 & \\
\hline \multicolumn{2}{|l|}{ Calamagrostis purpurascens } & 100 & & & & \\
\hline Deschampsia caespitosa & 500 & & 7000 & & 5000 & \\
\hline \multicolumn{7}{|l|}{ Deschampsia caespitosa } \\
\hline \multicolumn{7}{|l|}{ Elymus canadensis ${ }^{ \pm}$} \\
\hline Elymus canadensis & 300 & & & & & \\
\hline Elymus glaucus & & & 2000 & & 4000 & \\
\hline Elymus innovatus & 500 & & 500 & & & \\
\hline Glyceria grandis & & 1000 & & & & \\
\hline Panicum capillare & & 1000 & & & & \\
\hline Poa juncifolia & & & 1000 & & 4000 & \\
\hline Schizachyrium scoparium & 500 & & 500 & & 500 & \\
\hline Stipa viridula & 10000 & & 20000 & & 20000 & \\
\hline Stipa viridula & & & 4500 & & 4000 & \\
\hline \multicolumn{7}{|l|}{ Aquatics, Sedge, etc. } \\
\hline Alisma plantago-aquatica & & 150 & & & & \\
\hline Alisma plantago-aquatica & & 400 & & 600 & & 800 \\
\hline Calla palustris & & 150 & & & & \\
\hline Calla palustris & & 200 & & 300 & & 500 \\
\hline Caltha palustris & & 300 & & 450 & & 600 \\
\hline Carex aquatilis & & 100 & & & & \\
\hline Carex aquatilis & & 300 & & 400 & & 500 \\
\hline Eleocharis acicularis & & 100 & & 100 & & 100 \\
\hline Eleocharis palustris & & 2000 & & & & \\
\hline Eleocharis palustris & & 250 & & 400 & & 600 \\
\hline
\end{tabular}

"Note. Seed grower indicated that the particular species will be in production but no estimated values were provided. 


\begin{tabular}{|c|c|c|c|c|c|c|}
\hline \multirow{3}{*}{ Species } & \multicolumn{6}{|c|}{ Long-term production } \\
\hline & \multicolumn{2}{|c|}{2000} & \multicolumn{2}{|c|}{2002} & \multicolumn{2}{|c|}{2005} \\
\hline & $\mathrm{Kg}$. & \# Plts. & 3. & \# Plts. & 2005 & \# Plts. \\
\hline Equisetum hyemale & & 400 & & 300 & & 400 \\
\hline Hippuris vulgaris & & 200 & & & & \\
\hline Juncus balticus & & 200 & & & & \\
\hline Juncus ensifolius & & 300 & & 350 & & 400 \\
\hline Juncus nodosus & & 2000 & & & & \\
\hline Lemna minor & & 200 & & & & \\
\hline Lemna minor & & 400 & & 600 & & 800 \\
\hline Myriophyllum exalbescens & & 2000 & & & & \\
\hline Petasites sagittatus & & 100 & & & & \\
\hline Petasites sagittatus & & 200 & & 300 & & 400 \\
\hline Polygonum amphibium & & 1000 & & & & \\
\hline Ranunculus cymbalaria & - & 200 & & 300 & & 400 \\
\hline Sagittaria cuneata & & 500 & & & & \\
\hline Scirpus acutus & & 2000 & & & & \\
\hline Scirpus microcarpus & & 200 & & & & \\
\hline Scirpus validus & & 500 & & & & \\
\hline Triglochin maritima & & 500 & & & & \\
\hline Trlglochin maritima & & 150 & & 200 & & 250 \\
\hline \multicolumn{7}{|l|}{ Forbs } \\
\hline Antennaria rosea & & 1000 & & 1000 & & 1000 \\
\hline Aster alpinus & & 1000 & & 1000 & & 1000 \\
\hline Astragalus canadensis & & & 1000 & 5000 & & \\
\hline Caltha palustris & & 2000 & & 2000 & & 2000 \\
\hline Gaillardia aristata & & & & & 500 & \\
\hline Petalostemon purpureum & & 3000 & & 3000 & & \\
\hline Ratibida columnifera & 10 & & 20 & & 20 & \\
\hline \multicolumn{7}{|l|}{ Vicia americana } \\
\hline \multicolumn{7}{|l|}{ Woody plants } \\
\hline Arctostaphyios uva-ursi & & 10000 & & 10000 & & 10000 \\
\hline Betula papyrifera & & 100 & & & & \\
\hline Picea glauca & & 1000 & & & & \\
\hline Populus balsamifera & & 50 & & & & \\
\hline Populus tremuloides & & 750 & & & & \\
\hline Prunus pensylvanica & & 100 & & & & \\
\hline
\end{tabular}


APPENDIX 4 - Amount spent on native species, projected use and ecoregions of consumption

\begin{tabular}{|c|c|c|c|c|c|c|c|c|c|c|c|c|c|c|}
\hline \multirow[b]{3}{*}{ Species } & \multicolumn{9}{|c|}{ Quantity of Species } & \multicolumn{4}{|c|}{ Projected Use } & \multirow[b]{3}{*}{ Ecoregion } \\
\hline & \multicolumn{3}{|c|}{1997} & \multicolumn{3}{|c|}{1998} & \multicolumn{3}{|c|}{1999} & \multicolumn{2}{|c|}{ Year 2000} & \multicolumn{2}{|c|}{ Year 2001} & \\
\hline & $\mathrm{kg}$ & PIts & $\$$ & $\mathbf{k g}$ & Pits & $\$$ & $\mathbf{k g}$ & Pits & $\$$ & kg & PIts & kg & PIts & \\
\hline Agropyron albicans & & & & & & & & & & 50 & & 50 & & GP \\
\hline Agropyron dasystachyum & 6.3 & & 35 & & & & 4 & & 20 & 6 & & 6 & & GP \\
\hline Agropyron dasystachyum & 20 & & 250 & 20 & & 250 & & & & & & & & \\
\hline Agropyron dasystachyum & & & 20000 & & & 30000 & & & 25000 & 400 & & 400 & & GP \\
\hline \begin{tabular}{|l} 
Agropyron dasystachyum \\
\end{tabular} & 2 & & & 716 & & & 851 & & & 544 & & & & NWMF \\
\hline Agropyron smithii & 6.3 & & 35 & & & & 4 & & 20 & 6 & & 6 & & GP \\
\hline Agropyron smithii & 20 & & 250 & 20 & & 250 & & & & 400 & & 400 & & GP \\
\hline Agropyron smithii & & & & & & & & & & 1 & & & & \\
\hline Agropyron subsecundum & & & & & & & 270 & & 3800 & 300 & & & & Bor/MixW \\
\hline Agropyron subsecundum & & & & & & & & & & 50 & & 50 & & GP \\
\hline Agropyron riparium & 20 & & 250 & 20 & & 250 & & & & 6 & & 6 & & GP \\
\hline Agropyron riparium & 6.3 & & 35 & & & & 4 & & 20 & 400 & & 400 & & GP \\
\hline Agropyron trachycaulum & 20 & & 250 & 20 & & 250 & & & & 200 & & & & GP \\
\hline Agropyron trachycaulum & 6.3 & & 35 & & & & & & & 6 & & 6 & & GP \\
\hline Agropyron trachycaulum & & & & & & & & & & 400 & & 400 & & GP \\
\hline Agrostis scabra & & & & & & & 100 & & 2000 & & & & & Bo \\
\hline Bouteloua gracilis & 10 & & 600 & 10 & & 600 & & & & & & & & GP \\
\hline Bouteloua gracilis & 12 & & 700 & & & & & & & 12 & & 12 & & GP \\
\hline Bouteloua gracilis & & & & & & & & & & 1 & & & & GP \\
\hline Bromus anomalus & 2 & & & & & & & & & & & & & GP \\
\hline Bromus ciliatus & 625 & & 7450 & & & & 200 & & 2500 & 200 & & & & Bor/MixW \\
\hline Bromus ciliatus & 2 & & & & & & & & & & & & & GP \\
\hline Bromus carinatus & 478 & & & 568 & & & 362 & & & & & & & NWMF \\
\hline Calamovilfa longifolia & 2 & & & & & & & & & & & & & GP \\
\hline Deschampsia caespitosa & 175 & & 4540 & & & & 230 & & 5240 & 250 & & & & Boreal \\
\hline Elymus canadensis & & & & & & & & & & 2 & & 2 & & GP \\
\hline Elymus canadensis & 2 & & 10 & & & & 0.5 & & 10 & & & & & GP \\
\hline Elymus innovatus & 1 & & 5 & & & & & & & 2 & & 2 & & GP \\
\hline Elymus innovatus & 2 & & & & & & & & & & & & & GP \\
\hline Festuca saximontana & 225 & & 7410 & & & & 145 & & 4560 & 100 & & & & Boreal \\
\hline Festuca hallii & 1 & & 15 & & & & 0.5 & & 5 & 1 & & 1 & & GP \\
\hline Festuca hallii & 2 & & & & & & & & & & & & & \\
\hline Koeleria gracilis & & & & & & & & & & 1 & & 1 & & GP \\
\hline Koeleria gracilis & 175 & & 6990 & & & & 30 & & 1930 & 50 & & & & Boreal \\
\hline Koeleria gracilis & 2 & & & & & & & & & 1 & & & & GP \\
\hline Munroa squarrosa & 0 & & 250 & 20 & & 250 & & & & & & & & GP \\
\hline Poa alpina & 239 & & & 851 & & & 181 & & & & & & & NWMF \\
\hline Poa palustris & 375 & & 4480 & & & & 325 & & 3510 & 300 & & & & Boreal \\
\hline Poa sandbergii & 2 & & & & & & & & & & & & & GP \\
\hline Puccinellia nuttalliana & 1 & & 5 & & & & & & & 0.25 & & 0.3 & & GP \\
\hline Schizachyrium scoparium & 2 & & & & & & & & & & & & & GP \\
\hline Stipa comata & 2 & & 40 & & & & 0.5 & & 2 & 1 & & 1 & & GP \\
\hline Stipa comata & 2 & & & & & & & & & & & & & GP \\
\hline Stipa spartea & & & & & & & 0.5 & & 2 & 1 & & & & GP \\
\hline Stipa viridula & 2 & & 40 & & & & & & & 1 & & 1 & & GP \\
\hline
\end{tabular}




\begin{tabular}{|c|c|c|c|c|c|c|c|c|c|c|c|c|c|c|}
\hline \multirow[b]{3}{*}{ Species } & \multicolumn{9}{|c|}{ Quantity of Species } & \multicolumn{4}{|c|}{ Projected Use } & \multirow[b]{3}{*}{ Ecoregion } \\
\hline & \multicolumn{3}{|c|}{1997} & \multicolumn{3}{|c|}{1998} & \multicolumn{3}{|c|}{1999} & \multicolumn{2}{|c|}{ Year 2000} & \multicolumn{2}{|c|}{ Year 2001} & \\
\hline & kg & PIts & $\$$ & $\mathrm{~kg}$ & Plts & $\$$ & $\mathrm{~kg}$ & PIts & $\$$ & kg & PIts & $\mathbf{k g}$ & Plts & \\
\hline Stipa viridula & 2 & & & & & & & & & 1 & & & & GP \\
\hline Astragalus canadensis & 2 & & & & & & & & & & & & & GP \\
\hline Helianthus maximilianii & 2 & & & & & & & & & & & & & GP \\
\hline Lathyrus ochroleucus & 2 & & & & & & & & & & & & & GP \\
\hline Petalostemon purpureum & 2 & & & & & & & & & & & & & GP \\
\hline Petasites palmatus & 2 & & & & & & & & & & & & & GP \\
\hline Acer spp. & & 500 & 500 & & 300 & 300 & & 500 & 500 & & 500 & & 500 & NWFMtn \\
\hline Alnus crispa & & & & & & & & & & & 9000 & & 9000 & Bor/MixW \\
\hline Alnus crispa & & 100 & 75 & & 200 & 150 & & 500 & 400 & & 200 & & 200 & NWFMtn \\
\hline Amelanchier alnifolia & & & & & & & & & & & 7000 & & 7000 & Bor/MixW \\
\hline Betula glandulosa & & 200 & 175 & & 100 & 80 & & 100 & 100 & & 100 & & 100 & NWFMtn \\
\hline Comus stolonifera & & & & & & & & & & 4 & & & & NWFMtn \\
\hline Comus stolonifera & & & - & & & & & & & & 1000 & & 1000 & Bor/MixW \\
\hline Corylus cornuta & & 4000 & & & & & & 19240 & & & & & & Boreal \\
\hline Lonicera involucrata & & & & & 100 & 50 & & & & & & & & NWFMtn \\
\hline Picea glauca & & & & & & & & & & & 175000 & & 175000 & Bor/MixW \\
\hline Picea glauca & & & & & & & & & & 2 & & & & NWFMtn \\
\hline Picea glauca & & & & & 30700 & & & 6940 & & & 125000 & & & Boreal \\
\hline Picea mariana & & & & & & & & 4680 & & & & & & Boreal \\
\hline Pinus banksiana & & & & & & & & & - & & 24000 & & 24000 & Bor/MixW \\
\hline Pinus banksiana & & & & & & & & & & 2 & & & & NWFMtn \\
\hline Pinus banksiana & & 58800 & & & & & & 5520 & & & & & & NWFMtn \\
\hline Populus balsamifera & & 100 & 500 & & & & & & & & 7000 & & 7000 & Bor/MixW \\
\hline Populus tremuloides & & & & & & & & & & & 20000 & & 20000 & Bor/MixW \\
\hline Populus tremuloides & & & & & & & & & & 0.5 & & & & NWFMtn \\
\hline Populus tremuloides & & 58800 & & & 23500 & & & 37050 & & & 125000 & & & Boreal \\
\hline Prunus pensylvanica & & 300 & 300 & & & & & & & & & & & \\
\hline Rosa woodsii & & & & & & & & & & & 7000 & & 7000 & Bor/MixW \\
\hline Salix exigua & & & & & 100 & 50 & & & & & & & & NWF Mtn \\
\hline
\end{tabular}


APPENDIX 5 - Native Plant Market Assessment - Producer/Supplier Survey

Thank you for your assistance in helping us conducting the market assessment of the native plant industry in the western provinces. For our purpose, the following definition will be adopted.

Native plants are any species of plant that existed in western Canada, prior to European settlement.

Native plant material is any plant parts used for propagation such as seed, cuttings, rootstocks, bulbs, etc

Wild harvest is defined as plant material taken directly from the natural habitat.

Cultivated native is a species originally collected from the wild and grown for production

Cultivar is a named variety, which has been produced by artificial selection techniques for better performance.

Ecovar is an ecological variety (coined by Ducks Unlimited) of a native plant species artificially selected to produce a population containing maximum genetic variability.

A shrub is a woody plant, mostly less than $5 \mathrm{~m}$. tall and usually with several stems.

Legume refers to any plant in the Leguminosae family; the fruit consist of a dry pod. E.g. peas.

Forbs are primarily broad-leaved flowering plants with net-like veins.

Genetic origin is defined as the place where the plant material was first collected.

Map of Ecoregions of North America. http://www.cprc.uregina.ca/ccea/ecozones/level1.html

Map of Natural regions of Alberta. http://www.gov.ab.ca/env/parks/anhic/anhic.html

\section{Producer/ supplier Information}

1. Please indicate whether you are a producer, supplier or both of native plant materials. I am presently a:

Producer

$\square$ Yes

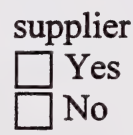

If no to neither one, please go to question \# 24,25 and 26 
2. During the last year, how much of your work time is devoted to the native plant business?

$\square>-100 \%$
$\square>60$ to $80 \%$
$\square>40$ to $60 \%$
$\square>20$ to $40 \%$
$\square<20 \%$

II. Production Information

3. How many years have you been in the native plants business? years

4. In 1998, how many acres / \# of plants did you have in production? Greenhouse operators, if plants are propagated, please use number of plants.

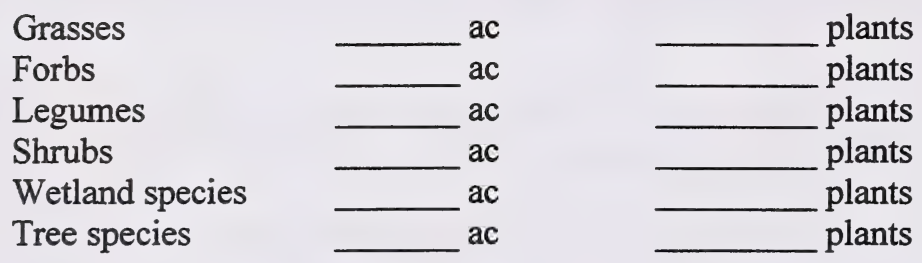

5. In 1998, what is your total native clean seed production.

$\mathrm{kg}$ from cultivation

$\mathrm{kg}$ from wild harvesting.

6. In 1998, what was your total gross revenue (\$) from sales of native plant materials?

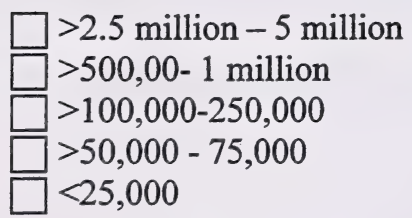

$\square>5$ million
$\square>1$ million -2.5 million
$\square>250,00-500,000$
$\square>75,000-100,000$
$\square>25,00-50,000$

7. From which of the following sources do you receive your native plant materials? Please check more than one if applicable. People doing wild harvesting, please answer question 12 and 13. Please check as many as apply.

$\square$ I collect the seed from native landscapes (wild harvest).

I collect the seed from my own crop

I purchase the seed from other producer.

$\square$ I purchase the seed from other supplier.

$\square$ Other (please specify) 
8. Do you follow any guidelines, for example as set up by the Alberta Native Plant Council when harvesting from native landscapes.

$\square$ I follow the Alberta Native Plant Council guidelines.

$\square$ I was not aware of any guidelines follow Saskatchewan Native Plant Council guidelines" Recommendations for the Collection \& Use of Native Plants".

$\square$ I follow the guidelines as set up by Public Lands, Alberta Agriculture, Food and Rural Development.

I am aware of the guidelines, but do not follow them.

$\square$ I follow similar guidelines from my location. (Please specify)

$\square$ I was not aware of any guidelines.

9. Please fill out the following table showing the species harvested from the wild, the amount harvested and the ecoregion region it was harvested. Please refer to map for ecoregions. A list of species has been provided for your convenience. Please use the number in the adjacent column instead of writing the species, unless the species is not listed. Use extra sheet if need be.

a. Seeds

\begin{tabular}{|l|c|c|c|c|}
\hline Species & $\begin{array}{c}\text { Amount of } \\
\text { seed } \\
\text { harvested } \\
(\mathrm{kg}) \text { in 1998 }\end{array}$ & $\begin{array}{c}\text { Ecoregions } \\
\text { seeds were } \\
\text { harvested }\end{array}$ & $\begin{array}{c}\text { Amount of } \\
\text { seed } \\
\text { harvested } \\
(\mathrm{kg}) \text { in } \\
1999\end{array}$ & $\begin{array}{c}\text { Ecoregions } \\
\text { seeds were } \\
\text { harvested }\end{array}$ \\
\hline & & & & \\
\hline & & & & \\
\hline & & & & \\
\hline & & & & \\
\hline & & & & \\
\hline & & & & \\
\hline & & & & \\
\hline
\end{tabular}

b. Plants

\begin{tabular}{|c|c|c|l|c|}
\hline Species & $\begin{array}{c}\text { Number of } \\
\text { plants } \\
\text { harvested in } \\
1998\end{array}$ & $\begin{array}{l}\text { Ecoregions } \\
\text { seeds were } \\
\text { harvested }\end{array}$ & $\begin{array}{l}\text { Number of } \\
\text { plants } \\
\text { harvested } \\
\text { in } 1999\end{array}$ & $\begin{array}{l}\text { Ecoregions } \\
\text { seeds were } \\
\text { harvested }\end{array}$ \\
\hline & & & & \\
\hline & & & & \\
\hline & & & & \\
\hline & & & & \\
\hline & & & & \\
\hline & & & & \\
\hline & & & & \\
\hline & & & & \\
\hline
\end{tabular}


10. If native plant material is purchased from other producers/suppliers, from which province (state) do they originate?

$\begin{array}{ll}\square & \text { Alberta } \\ \square & \text { British Columbia } \\ \square & \text { Manitoba } \\ \square & \text { Saskatchewan } \\ \square & \text { United States }\end{array}$

State

11. If native plant material is purchased from other producers/suppliers, from which ecoregion do they originate?

$\square$ Great Plains
$\square$ Tundra
$\square$ Taiga
$\square$ Arctic Cordillera
$\square$ North American Desert
$\square$ North Western Forest Mountain
$\square$ Northern Forest
$\square$ Other
$\square$ Don't know

12. If native plant material is purchased from other producers/suppliers, from which natural region do they originate?

$\square$ Grassland
$\square$ Parkland
$\square$ Foothills
$\square$ Rocky Mountains
$\square$ Boreal

13. For each statement below, please rate on a scale of 1 to 5 ( 1 being strongly disagree, 5 strongly agree and 0 being no opinion.) your level of agreement of each statement. (Circle a number.)

\section{Statement:}

a: ecovar is an acceptable source of native plant material.

$\mathrm{b}$ : cultivar is an acceptable source of native plant material.

c: wild harvesting is an acceptable source of native plant material. 122345 
14. Please identify your 1998 and 1999 production by species and variety, including, amount sold and place of seed origin. (please use extra sheets if necessary). A list of species has been provided for your convenience. Please use the number in the adjacent column instead of writing the species, unless the species is not listed. Use extra sheet if need be.

a. Seeds

Native seeds

Amount sold (kg)

Place of genetic origin

(Ecoregion)

\begin{tabular}{|l|l|l|l|l|}
\hline & 1998 & 1999 & 1998 & 1999 \\
\hline & & & & \\
\hline & & & & \\
\hline & & & & \\
\hline & & & & \\
\hline & & & & \\
\hline & & & & \\
\hline & & & & \\
\hline & & & & \\
\hline & & & & \\
\hline & & & & \\
\hline & & & & \\
\hline & & & & \\
\hline & & & & \\
\hline
\end{tabular}

b. Plants

Native plants

Amount sold (kg)

Place of genetic origin

\begin{tabular}{|l|l|l|l|l|}
\hline & 1998 & 1999 & 1998 & 1999 \\
\hline & & & & \\
\hline & & & & \\
\hline & & & & \\
\hline & & & & \\
\hline & & & & \\
\hline & & & & \\
\hline & & & & \\
\hline & & & & \\
\hline & & & & \\
\hline & & & & \\
\hline & & & & \\
\hline & & & & \\
\hline
\end{tabular}


III. Marketing/ processing information

15. What percent of your native plant material sold is appropriate. (Sum to $100 \%$ ). . Select all options, which are

$\square$ Cleaned
$\square$ Not cleaned
$\square$ Mixed with other species
$\square$ Certified (named varieties)
$\square$ Tested for germination and purity
$\square$ I do not process the seed prior to selling.
$\square$ Treated
$\square$ Other

16. Do you sell all the native plant material in a typical year?

$\square$ Yes.

No. On average, what is the percentage of crop that is carried over? $\%$.

17. What information do you provide to the users of native plant species?

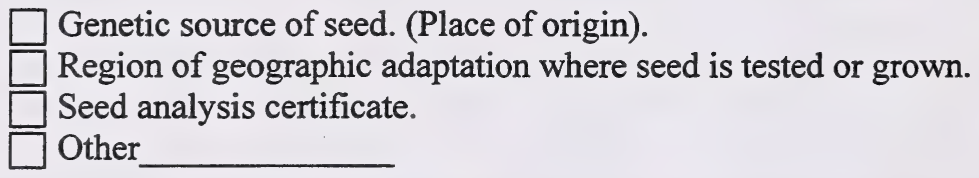

18. What percentage of the product is sold within the following distances, from your place of business? Please fill in all that apply.

$\% 0-50 \mathrm{~km}$
$\% 51-100 \mathrm{~km}$
$\% 101-200 \mathrm{~km}$
$\%$ Over $200 \mathrm{~km}$
$\%$ Abroad (overseas)
$\%$ Other (please specify)

19. Please identify the natural region where your native plant material sold last year, was used (check as many as apply). Sum up to $\mathbf{1 0 0 \%}$.

$\square$ Grassland
$\square$ Parkland
$\square$ Foothills
$\square$ Rocky Mountains
$\square$ Boreal
$\square$ Don't know

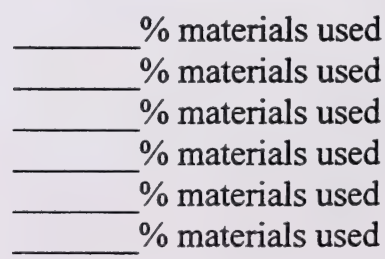


20. Please identify the ecoregion where your native plant material, sold last year, was used (check as many as apply). Sum up to $100 \%$.
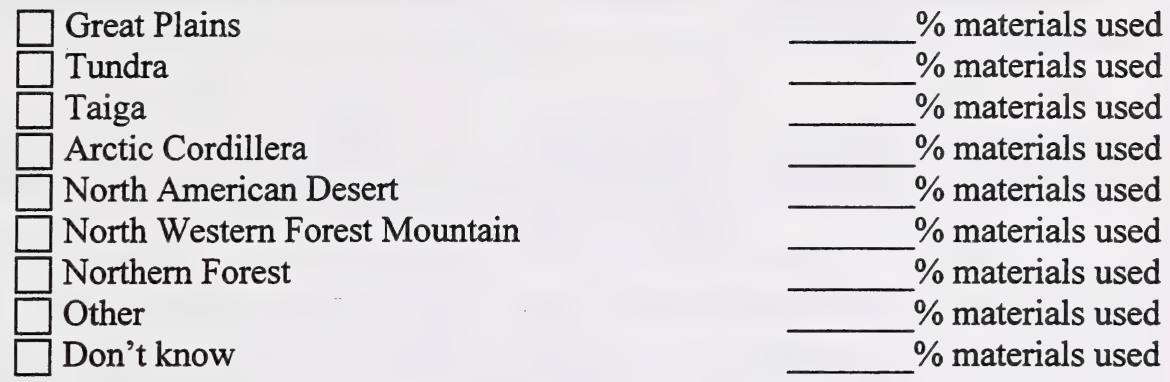

21. Please identify the province where your native plant material sold last year, was used (check as many as apply). Sum up to $100 \%$.

$\begin{array}{ll}\square & \text { Alberta } \\ \square & \text { British Columbia } \\ \square & \text { Saskatchewan } \\ \square & \text { Manitoba } \\ \square & \text { United States (State } \\ \square & \text { Don't know }\end{array}$

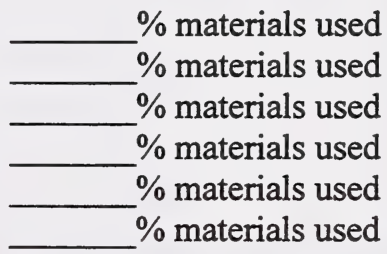

22. How do you market your products? check all that apply.

$\begin{array}{ll}\square & \text { On-farm sales } \\ \square & \text { Contract } \\ \square & \text { Farmer's market } \\ \square & \text { Roadside stands } \\ \square & \text { Mail order } \\ \square & \text { Internet } \\ \square & \text { Other }\end{array}$

23. What percentage of your product is sold to the following sectors Sum to $100 \%$.

(a) $\square$ Reclamation industry

- $\square$ oil \& gas

- $\square$ sand \& gravel

- $\square$ roadways \& railways

- $\square$ mines

(b) $\square$ Agriculture

(c) $\square$ Horticulture

(d) $\square$ Landscaping

(e) $\square$ Wild life habitat restoration

(f) Wetland restoration

(g) $\square$ Medicinal uses

(h) $\square$ Reforestation

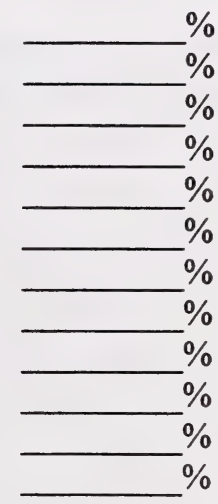


24. Please identify your short and long term production plan for native plant materials. Please use extra sheet, if need be. A list of species has been provided for your convenience. Please use the number in the adjacent column instead of writing the species, unless the species is not listed.

\begin{tabular}{|l|c|c|c|c|c|c|}
\hline Native plant species & \multicolumn{2}{|c|}{2000 Acreage } & \multicolumn{2}{c|}{2002 Acreage } & \multicolumn{2}{c|}{2005 Acreage } \\
\hline & $\begin{array}{c}\text { Seed } \\
(\mathrm{kg})\end{array}$ & $\begin{array}{c}\text { \# of } \\
\text { plants }\end{array}$ & $\begin{array}{c}\text { Seed } \\
(\mathrm{kg})\end{array}$ & $\begin{array}{c}\text { \# of } \\
\text { plants }\end{array}$ & $\begin{array}{c}\text { Seed } \\
(\mathrm{kg})\end{array}$ & $\begin{array}{c}\text { \# of } \\
\text { plants }\end{array}$ \\
\hline & & & & & & \\
\hline & & & & & & \\
\hline & & & & & & \\
\hline & & & & & & \\
\hline & & & & & & \\
\hline & & & & & & \\
\hline & & & & & & \\
\hline & & & & & & \\
\hline & & & & & & \\
\hline & & & & & & \\
\hline
\end{tabular}

25. Are any of the species targeted for future production, based on information provided in the (Check all that apply).

$\square$ "Guide to Using Native Plants on Disturbed Lands". By H. Gerling, M. Willoughby. A. Schoepf, C. Tannas and K. Tannas. 1996.

$\square$ Recommended Native Grasses and Legumes for Revegetating Disturbed Lands in the Green Area. Land and Forest Service. Alberta Environmental Protection. 1996.

$\square$ Guidelines as set up by Public Lands, Alberta Agriculture, Food and Rural Development: Appendix F -Commercial Availability of Native Plant and Appendix $\mathrm{H}$ - Available Native Plant for Use in Alberta.

$\square$ I follow some other guidelines. (Specify)

$\square$ Speculation.

$\square$ None of the above.

26. Please identify and discuss what you believe to be obstacles in the expansion of your native plant materials business. Topic may includes production, seed sources, availability of markets, Cost, etc. 
Thank you kindly for participating in our survey.

PLEASE RETURN SURVEY BY DECEMBER $10^{\text {th }}$ IN ENVELOPE PROVIDED. A COPY OF THE SURVEY RESULTS WILL BE MAILED OUT TO YOU BY NEXT APRIL.

Name:

Business:

Address:

City/State:

Phone \#:

FAX\#:

E-Mail: 
Thank you for your assistance in helping us, conducting the market assessment of the native plant industry in the western provinces. For our purpose, the following definition will be adopted.

Native plants are any species of plant that existed prior to European settlement.

Native plant material is any plant parts used for propagation such as seed, cuttings, rootstocks, bulbs, etc

Wild harvest is defined as plant material taken directly from its natural habitat.

Cultivated native is a species originally collected from the wild and grown for production

Cultivar is a named variety, which has been produced by artificial selection techniques for better performance.

Ecovar is an ecological variety of a native plant species (coined by Ducks Unlimited) artificially selected to produce a population containing maximum genetic variability.

A shrub is a woody plant, mostly less than $5 \mathrm{~m}$. tall and usually with several stems.

Legume refers to any plant in the Leguminosae family; the fruit consist of a dry pod. E.g. peas.

Forbs are primarily broad-leaved flowering plants with net-like veins.

Genetic origin is defined as the place where the plant material was first collected in the wild.

Map of Ecoregions of North America. http://www.cprc.uregina.ca/ccea/ecozones/levell.html

Map of Natural regions of Alberta. http://www.gov.ab.ca/env/parks/anhic/anhic.html

1. For how many years have you been using native plant materials?

$\square \frac{\text { Year(s) }}{\square \text { I have not purchased or used native plant materials in the past. (If not a user, please }}$ answer question $2 \& 13$.

2. I do not use native plants because. (Please check as many as apply.)

$\square$ Lack of available species.

Seeds/plant materials are too expensive.

Lack of production information.

Lack of quality

Equipment

Other (Please specify) 
3. Why are native plant materials used in your particular industry? (Please check as many as apply.)

$\square$ Native plants performed better than introduced species.

$\square$ Because of changing regulation governing the industry.

Increase diversity.

$\square$ Other (Please specify)

4. For each statement below, please rate on a scale of 1 to 5 ( 1 being strongly disagree, 5 strongly agree and 0 being no opinion.) your level of agreement of each statement. (Circle a number.)

\section{Statement:}

a: ecovar is an acceptable source of native plant material.

b: cultivar is an acceptable source of native plant material.

c: wild harvesting is an acceptable source of native plant material. $\begin{array}{llllll}1 & 2 & 3 & 4 & 5 & 0\end{array}$

5. Please complete the following table. For each species of grass, wildflower (forbs \& legumes), shrubs, provide the quantity purchased, amount spent (\$), and the Ecoregion in which the seed was used. A list of species has been provided for your convenience. Please use the number in the adjacent column instead of writing the species, unless the species is not listed. Use extra sheet if need be

\begin{tabular}{|l|l|l|l|l|l|l|l|l|l|}
\hline Species & \multicolumn{3}{|c|}{1997} & \multicolumn{3}{c|}{1998} & \multicolumn{3}{c|}{1999} \\
\hline & $\begin{array}{l}\text { Amt. of } \\
\text { materials } \\
\text { bought }\end{array}$ & $\begin{array}{l}\text { Amt. } \\
\text { spent } \\
\text { (\$) }\end{array}$ & $\begin{array}{l}\text { Ecoregion } \\
\text { used }\end{array}$ & $\begin{array}{l}\text { Amt. of } \\
\text { materials } \\
\text { bought }\end{array}$ & $\begin{array}{l}\text { Amt. } \\
\text { spent } \\
\text { (\$) }\end{array}$ & $\begin{array}{l}\text { Ecoregion } \\
\text { used }\end{array}$ & $\begin{array}{l}\text { Amt. of } \\
\text { materials } \\
\text { bought }\end{array}$ & $\begin{array}{l}\text { Amt. } \\
\text { spent (\$) }\end{array}$ & $\begin{array}{l}\text { Ecoregion } \\
\text { used }\end{array}$ \\
\hline & & & & & & & & & \\
\hline & & & & & & & & & \\
\hline & & & & & & & & & \\
\hline & & & & & & & & & \\
\hline & & & & & & & & & \\
\hline & & & & & & & & & \\
\hline & & & & & & & & & \\
\hline & & & & & & & & & \\
\hline & & & & & & & & & \\
\hline & & & & & & & & & \\
\hline
\end{tabular}


6. Which of the following sector best represent the industry for which you have purchased any of the native plant materials? Also, please indicate the amount (percent) of seeds or plants species used in each of these sector.

(a) $\square$ Reclamation industry

- $\square$ oil \& gas

- $\square$ sand \& gravel

- $\square$ roadways \& railways

- $\square$ mines

(b) $\square$ Agriculture

(c) $\square$ Horticulture

(d) $\square$ Landscaping

(e) $\square$ Wildlife habitat restoration

(f) Wetland restoration

(g) $\square$ Medicinal uses

(h) $\square$ Landfill

(i) $\square$ Reforestation

(j) $\square$ Other

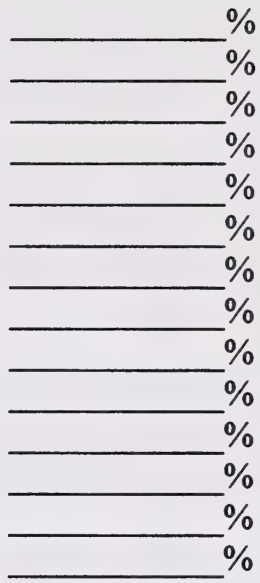

7. What is the distance between your place of business and your native plant materials grower or supplier?

Grower

\begin{tabular}{c}
$0-50 \mathrm{~km}$ \\
$51-100 \mathrm{~km}$ \\
$101-200 \mathrm{~km}$ \\
Over $200 \mathrm{~km}$ \\
\hline$\square$ Other (Please specify)
\end{tabular}

\section{Supplier}

\begin{aligned} & $0-50 \mathrm{~km} \\ & 51-100 \mathrm{~km} \\ & 101-200 \mathrm{~km} \\ &$ Over $200 \mathrm{~km} \\ &$\hline$\square$ Other (Please specify) \end{aligned}

8. Please identify the ecoregion where the native plant materials bought were used, (check as many as apply). Please refer to ecoregion map.

$\begin{array}{ll}\square & \text { Great Plains } \\ \square & \text { Tundra } \\ \square & \text { Taiga } \\ \square & \text { Arctic Cordillera } \\ \square & \text { North American Desert } \\ \square & \text { Northern Forest } \\ \square & \text { North Western Forest Mountain } \\ \square & \text { Other } \\ \square & \text { Don't know }\end{array}$


9. Please identify the geographical area where the native plant materials bought were used, (check as many as apply).

$\square$ Grassland
$\square$ Parkland
$\square$ Foothills
$\square$ Rocky Mountains
$\square$ Boreal
$\square$ Don't know

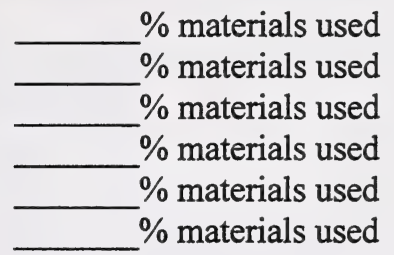

10. Do you know the geographical origin (original genetic source) of the native plant material you purchased last year or in past years?.

$\square$ I know the geographical origin of all native plant materials I purchased.

I know the geographical origin of some native plant materials I purchased.

I do not know the geographical origin of any native plant materials I purchased, wish I did.

$\square$ I do not know the geographical origin of any native plant materials I purchased, but it does not matter.

11. Does the grower/supplier provide you with any information regarding the native plant materials you purchased?

$\square$ Seed analysis (purity \& germination)

12. In your opinion, what has to be done to increase the use of native species.

$\square$ Increase research for development of native species.

Increasing public awareness on the use of native species by holding workshops, etc.

$\square$ Other (Please specify) 
13. Please fill the following table, based on your anticipated use of native plants in the future. A list of species has been provided for your convenience. Please use the number in the adjacent column instead of writing the species, unless the species is not listed. Use extra sheet if need be.

\begin{tabular}{|c|c|c|c|c|c|c|}
\hline \multirow[t]{3}{*}{ Species } & \multicolumn{2}{|c|}{ Projected use } & $\begin{array}{l}\text { Ecoregion plant } \\
\text { materials to be } \\
\text { used }\end{array}$ & \multicolumn{2}{|c|}{$\begin{array}{c}\text { Projected use } \\
\text { (kg of seed } \\
\text { or } \\
\text { \# of plants) }\end{array}$} & $\begin{array}{l}\text { Ecoregion } \\
\text { plant } \\
\text { materials to } \\
\text { be used }\end{array}$ \\
\hline & \multicolumn{2}{|c|}{ Year 2000} & & \multicolumn{2}{|c|}{ Year 2001} & \\
\hline & $\begin{array}{l}\text { Seed } \\
(\mathrm{kg})\end{array}$ & $\begin{array}{l}\text { \# of } \\
\text { plants }\end{array}$ & & $\begin{array}{l}\text { Seed } \\
(\mathrm{kg})\end{array}$ & $\begin{array}{l}\text { \# of } \\
\text { plants }\end{array}$ & \\
\hline & & & & & & \\
\hline & & & & & & \\
\hline & & & & & & \\
\hline & & & & & & \\
\hline & & & & & & \\
\hline & & & & & & \\
\hline & & & & & & \\
\hline & & & & & & \\
\hline & & & & & & \\
\hline & & & & & & \\
\hline
\end{tabular}

\section{Comments}

\section{Thank you kindly for participating in our survey.}

Name:

Business:

Address:

City/State:

Phone \#:

FAX \#:

E-Mail:

PLEASE RETURN SURVEY BY DECEMBER $10^{\text {th }}$ IN ENVELOPE PROVIDED. SURVEY RESULTS WILL BE MAILED OUT BY APRIL 


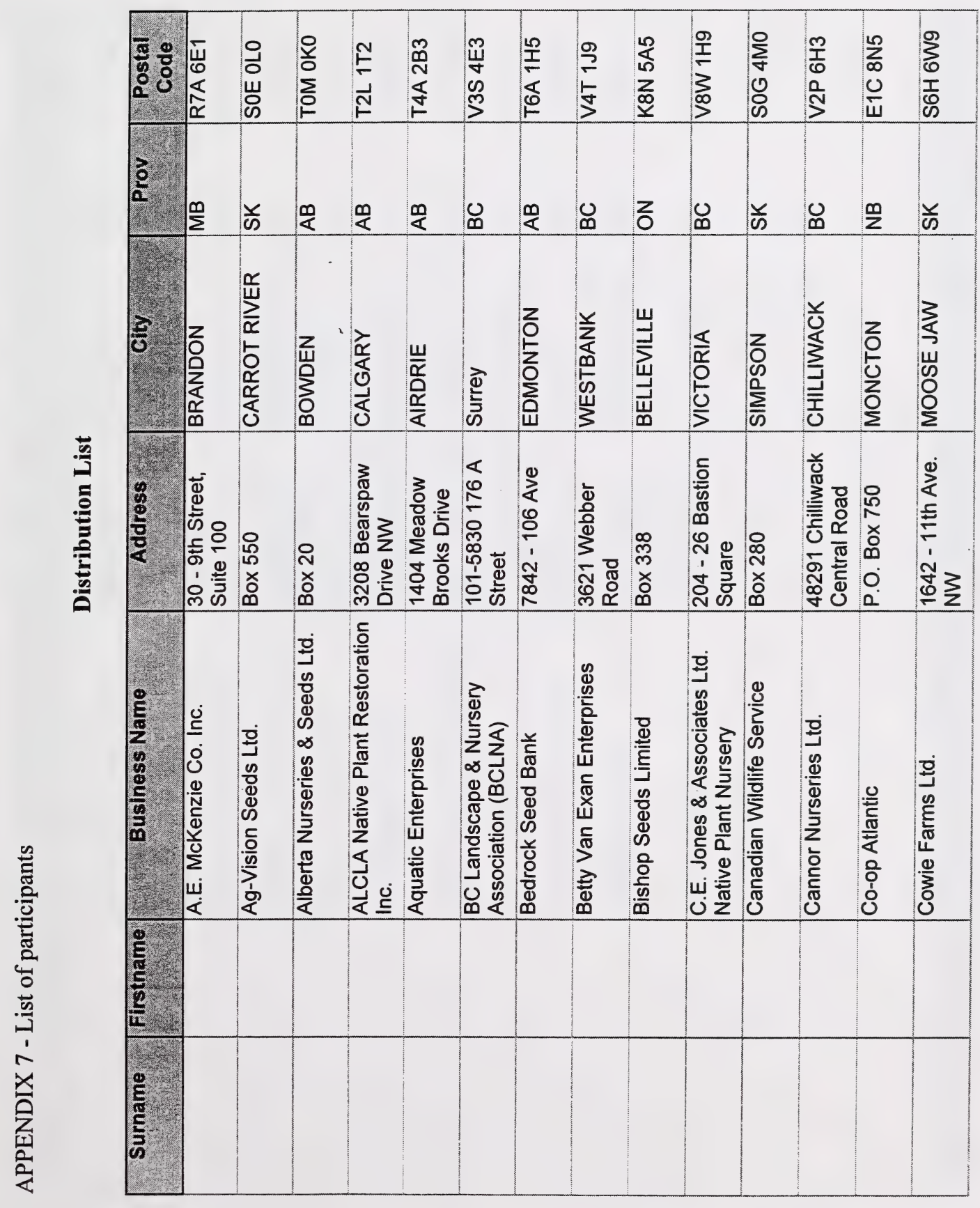




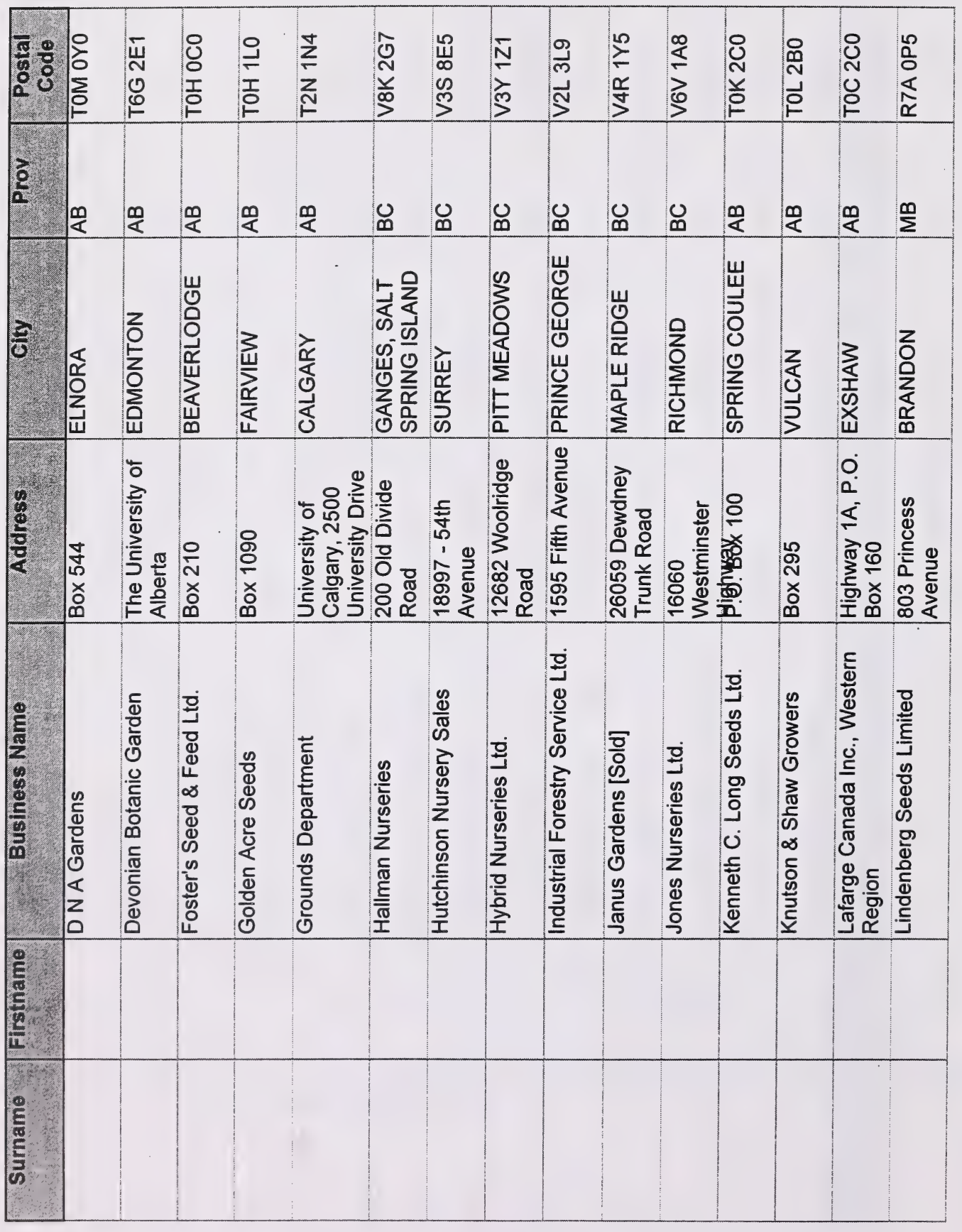




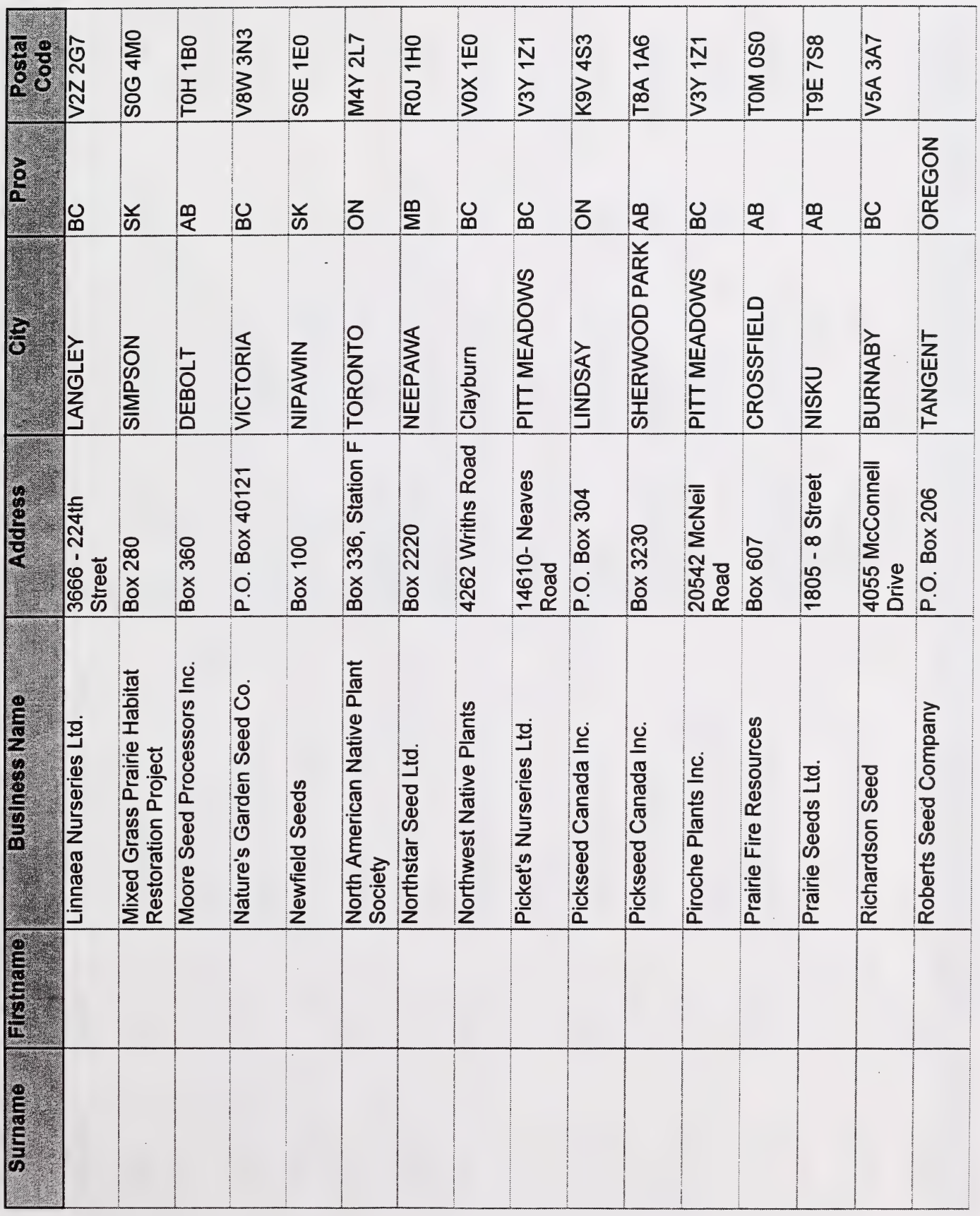




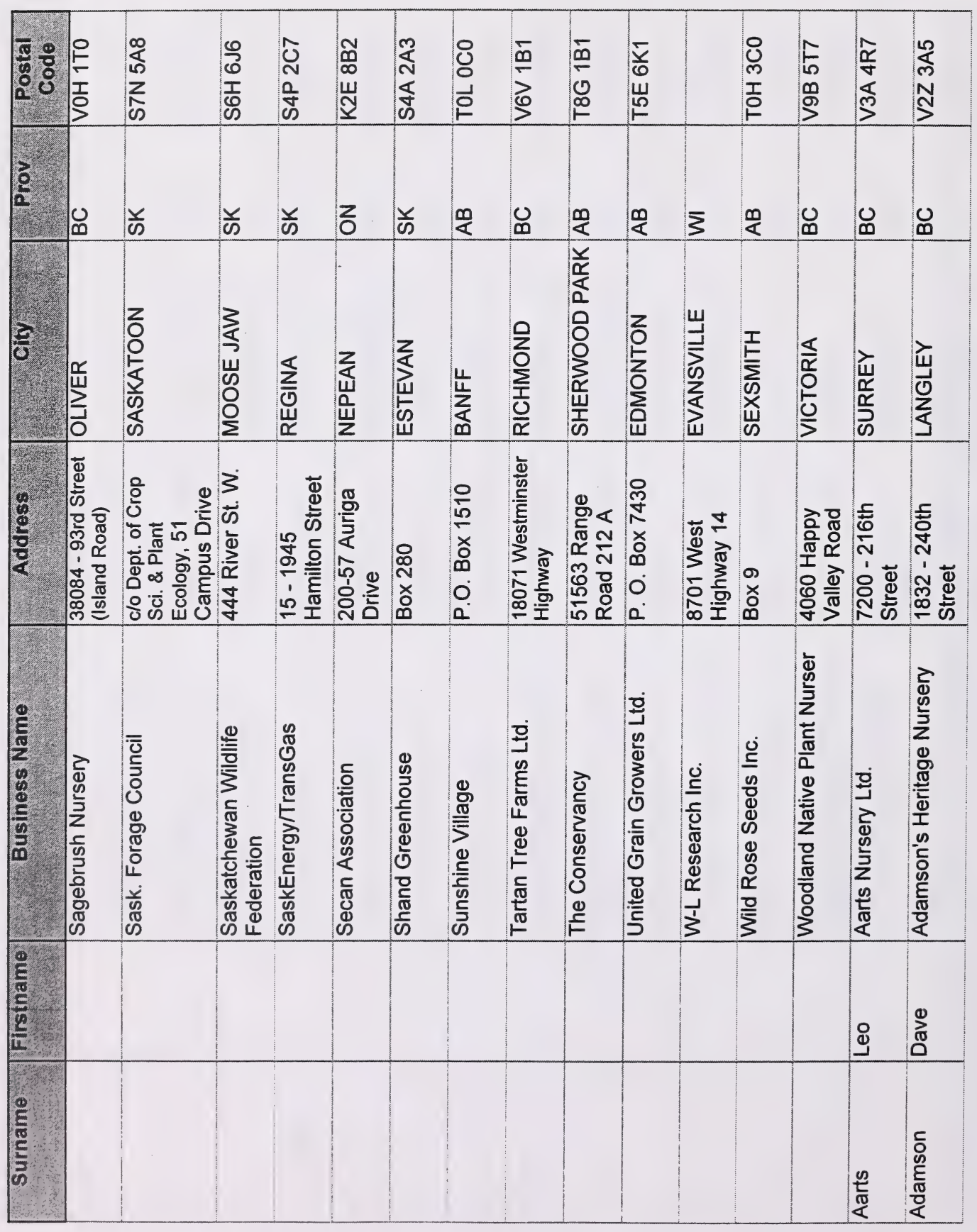




\begin{tabular}{|c|c|c|c|c|c|c|c|c|c|c|c|c|c|c|c|c|c|}
\hline 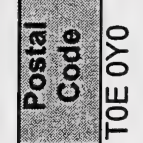 & $\begin{array}{l}8 \\
0 \\
0 \\
0 \\
0 \\
c\end{array}$ & 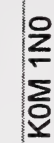 & & 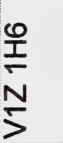 & $\begin{array}{l}\frac{9}{T} \\
\text { 岁 } \\
\text { S }\end{array}$ & $\frac{\bar{\alpha}}{\frac{\bar{g}}{z}}$ & $\sum_{\substack{f \\
s}}^{\infty}$ & 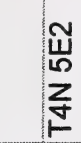 & 宫 & 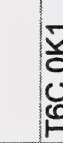 & & & 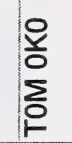 & & $\begin{array}{l}\mathscr{L} \\
0 \\
0 \\
\hat{\omega} \\
\hat{\omega}\end{array}$ & $\begin{array}{l}0 \\
\vdots \\
0 \\
0 \\
0 \\
\alpha\end{array}$ & $\begin{array}{l}\text { Oे } \\
\text { Ñ } \\
\text { o }\end{array}$ \\
\hline & or & zo & & 迎 & 迎 & 巡 & के & $\frac{\infty}{2}$ & के & $\frac{m}{4}$ & $\frac{\rho}{2}$ & $\Sigma$ & $\frac{\infty}{<}$ & $\sum$ & क & $\left.\right|^{1}$ & $\frac{x}{\omega}$ \\
\hline 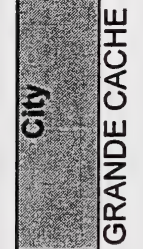 & 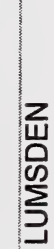 & 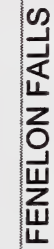 & & 选 & 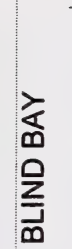 & 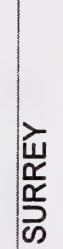 & 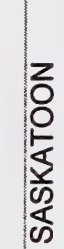 & 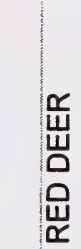 & 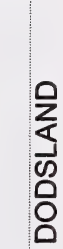 & $\begin{array}{l}\text { z } \\
\text { z } \\
\text { o } \\
\text { ù }\end{array}$ & & 岂 & $\sum_{\substack{u\\
}}^{z}$ & 啇 & 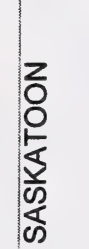 & $\begin{array}{l}0 \\
\frac{0}{0} \\
0 \\
0 \\
\frac{\alpha}{<}\end{array}$ & 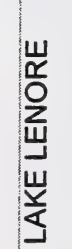 \\
\hline 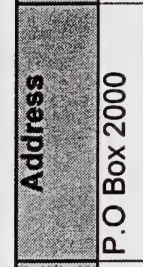 & 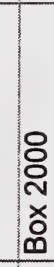 & $\begin{array}{l}\infty \\
\dot{\alpha} \\
\alpha \\
\alpha\end{array}$ & & 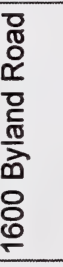 & 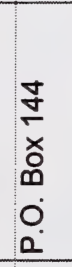 & 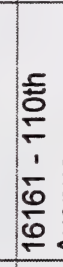 & 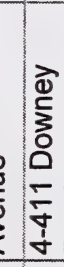 & 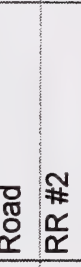 & 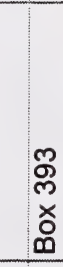 & $\begin{array}{l}0 \\
2 \\
0 \\
0 \\
1 \\
2 \\
2 \\
0 \\
0 \\
0\end{array}$ & 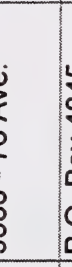 & 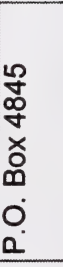 & 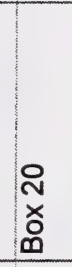 & 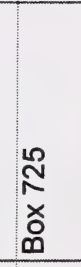 & 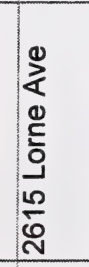 & 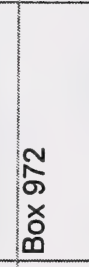 & \begin{tabular}{|l}
$\tilde{Z}$ \\
X̊ \\
0 \\
\end{tabular} \\
\hline 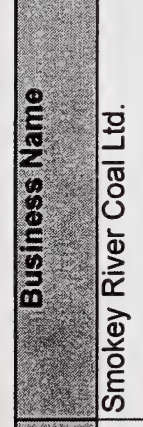 & 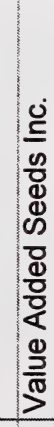 & 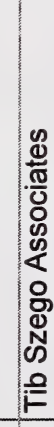 & & 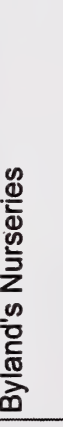 & 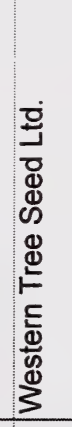 & 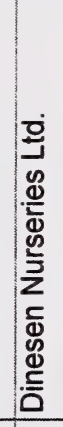 & 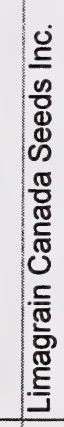 & 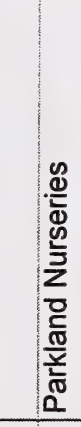 & & 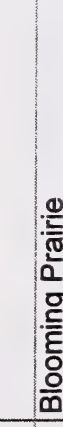 & & 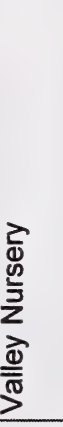 & 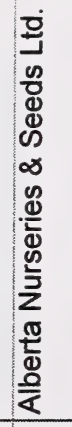 & 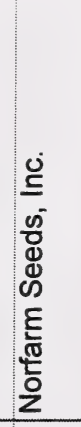 & 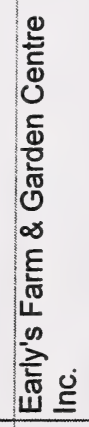 & 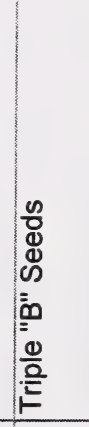 & \\
\hline${ }^{5}$ & 동 & 응 & & हE & 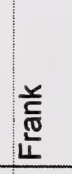 & 咅 & $\begin{array}{l}\text { 离 } \\
0\end{array}$ & $\frac{\pi}{0}$ & . & 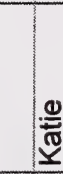 & & 逑 & 兽 & 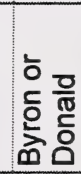 & ن. & 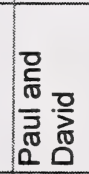 & ๘. \\
\hline $\mid \frac{5}{\frac{5}{2}}$ & $\frac{\bar{\sigma}}{\bar{\psi}}$ & $\ll$ & & 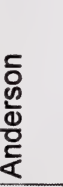 & 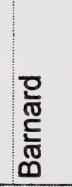 & $\infty$ & 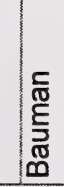 & 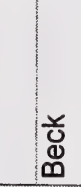 & Ф & 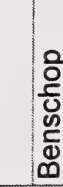 & & $\bar{\Phi}$ & 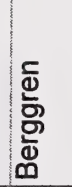 & 胥 & $\frac{\mathrm{x}}{\frac{0}{0}}$ & 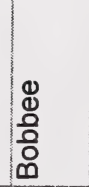 & $\frac{\bar{\omega}}{\overline{\frac{\omega}{\omega}}}$ \\
\hline
\end{tabular}




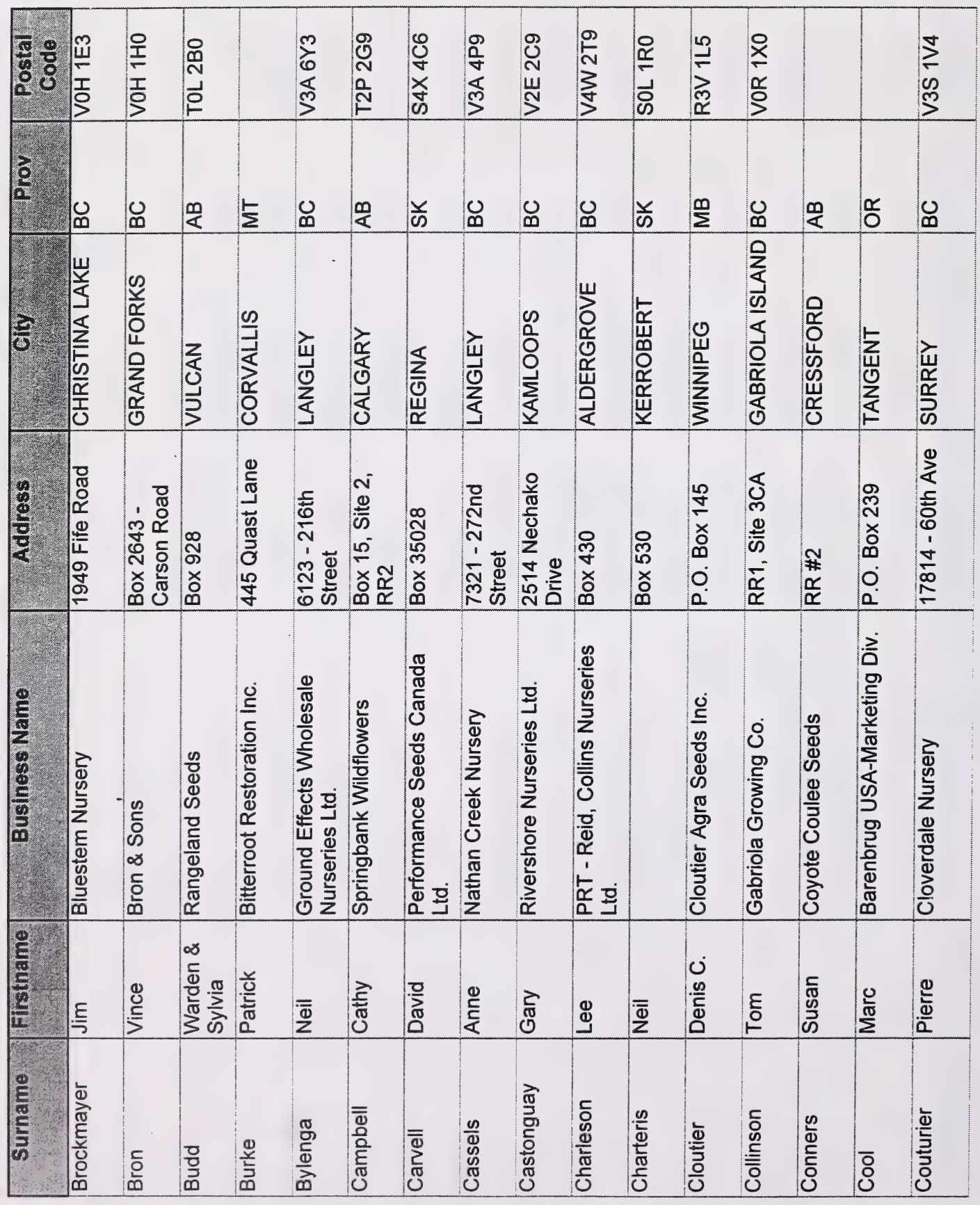




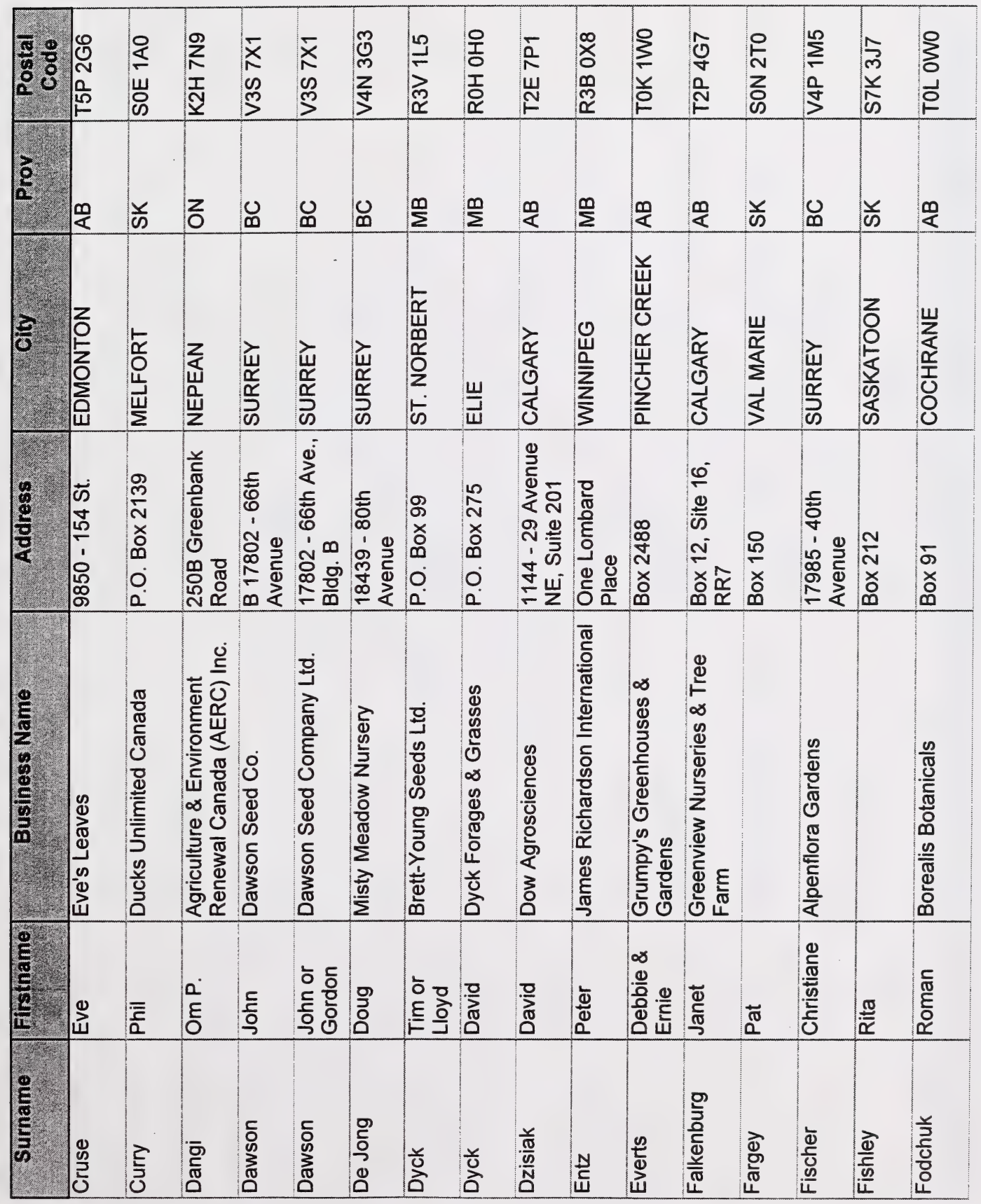




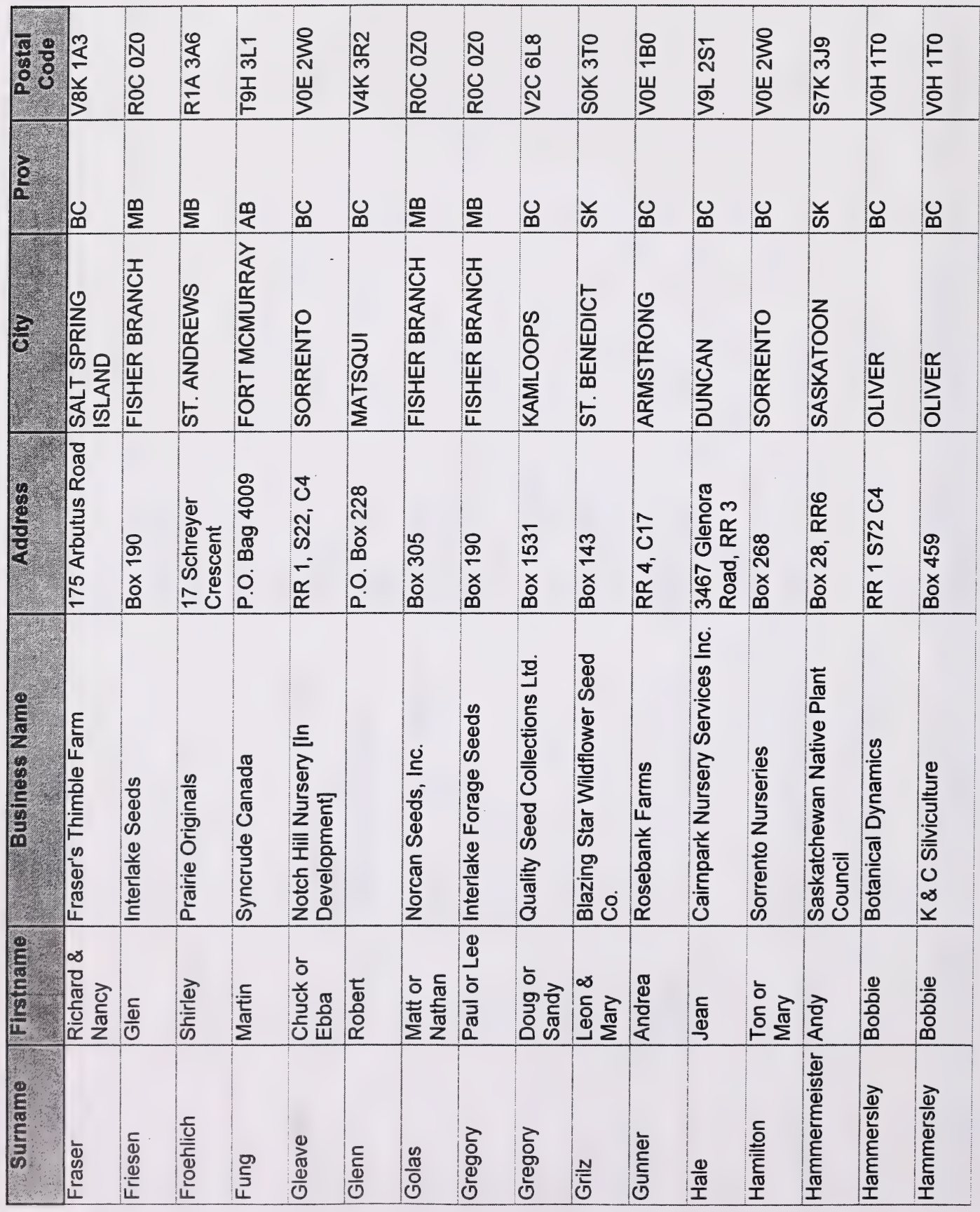




\begin{tabular}{|c|c|c|c|c|c|c|c|c|c|c|c|c|c|c|c|c|c|}
\hline 要: & $\begin{array}{l}\frac{8}{0} \\
\frac{0}{\infty} \\
j\end{array}$ & $\begin{array}{l}\hat{y} \\
\mathrm{z} \\
\mathrm{S}\end{array}$ & $\begin{array}{l}\delta \\
i \\
\vdots \\
\delta \\
\delta\end{array}$ & $\begin{array}{l}\text { N } \\
\text { ồ } \\
\text { ch }\end{array}$ & $\begin{array}{l}\frac{2}{2} \\
\frac{2}{1} \\
\frac{2}{1}\end{array}$ & 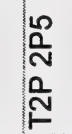 & $\begin{array}{l}2 \\
N \\
0 \\
0 \\
1\end{array}$ & & $\begin{array}{l}10 \\
\text { ర্ల } \\
0\end{array}$ & & 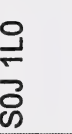 & $\begin{array}{l}\infty \\
\text { D } \\
\text { 广్ } \\
\text { s }\end{array}$ & \begin{tabular}{l}
0 \\
0 \\
0 \\
0 \\
\hdashline
\end{tabular} & $\begin{array}{l}\frac{\partial}{x} \\
\frac{x}{q} \\
a\end{array}$ & 仓े & 点 & $\begin{array}{l}\stackrel{9}{2} \\
\stackrel{1}{2} \\
\stackrel{2}{2}\end{array}$ \\
\hline & ర్ల & 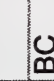 & & 崩 & $\frac{\infty}{2}$ & $\frac{m}{<}$ & $\frac{m}{2}$ & $\Sigma$ & $\sum_{\Sigma}^{\infty}$ & & है & U্口 & $\sum_{\Sigma}^{\infty}$ & $\sum_{\Sigma}^{\infty}$ & के & 迎 & $\frac{1}{4}$ \\
\hline & $\begin{array}{l}z \\
0 \\
b \\
w \\
0 \\
0\end{array}$ & 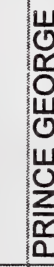 & 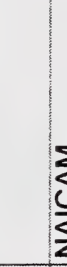 & $\begin{array}{l}\frac{\sum_{2}}{\sum_{0}} \\
\frac{1}{2}\end{array}$ & 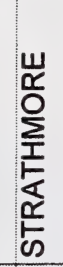 & 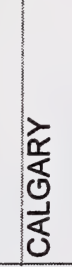 & 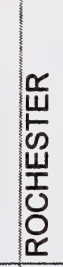 & 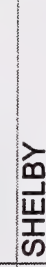 & 足 & & 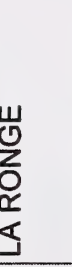 & 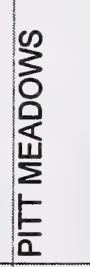 & 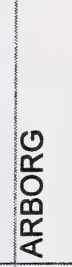 & $\sum_{\substack{\mathbb{R} \\
\mathbb{R}}}^{\infty}$ & 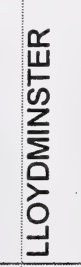 & $\frac{\text { 殅 }}{\omega}$ & 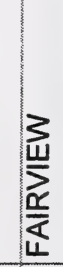 \\
\hline 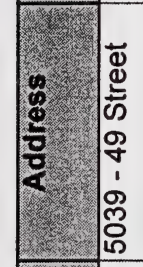 & 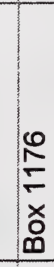 & $\begin{array}{l}\infty \\
\infty \\
\infty \\
\widetilde{a} \\
\widetilde{\partial} \\
0 \\
0 \\
0 \\
0 \\
0\end{array}$ & 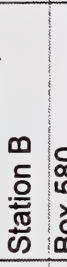 & & 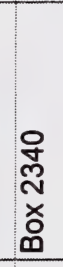 & 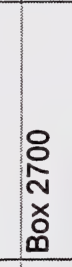 & 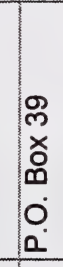 & 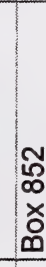 & 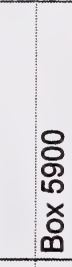 & & 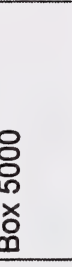 & 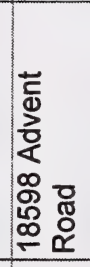 & 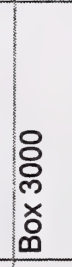 & 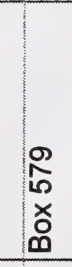 & 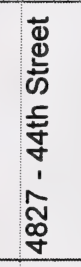 & 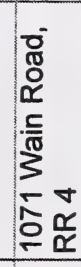 & 8 \\
\hline$\frac{8}{0}$ & 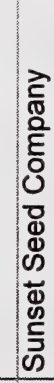 & 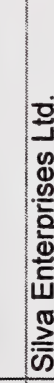 & 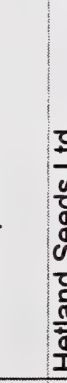 & 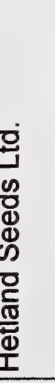 & 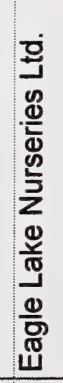 & 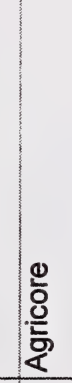 & 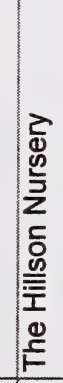 & 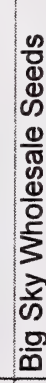 & 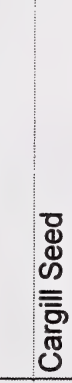 & & 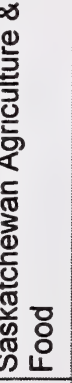 & 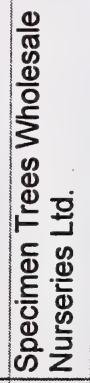 & 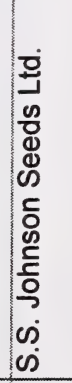 & 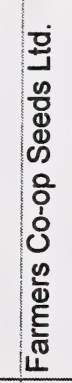 & 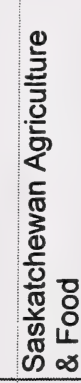 & 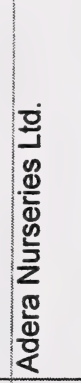 & 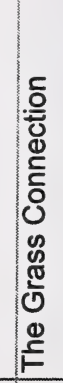 \\
\hline$\frac{\pi}{0}$ & ס् & $\frac{\bar{\omega}}{\sigma}$ & & 言 & 亳 & 。요 & 总 & స్ & 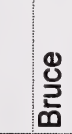 & $\begin{array}{l}\text { Z } \\
\text { d }\end{array}$ & 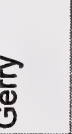 & 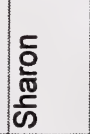 & 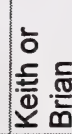 & $\stackrel{\circ}{\circ}$ & 흠 & 동 & 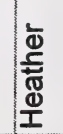 \\
\hline 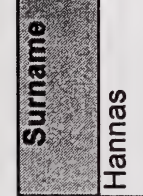 & \begin{tabular}{|l}
$\overline{\mathbb{\Xi}}$ \\
$\mathbb{\Phi}$
\end{tabular} & 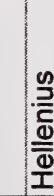 & 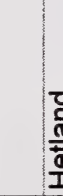 & 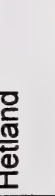 & 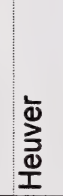 & 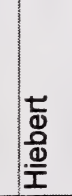 & 它 & & 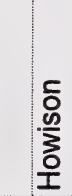 & 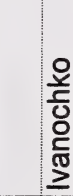 & 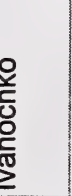 & 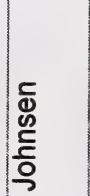 & 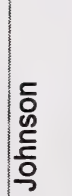 & 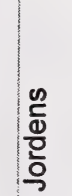 & 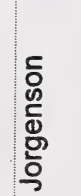 & 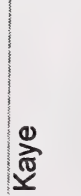 & 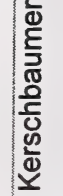 \\
\hline
\end{tabular}




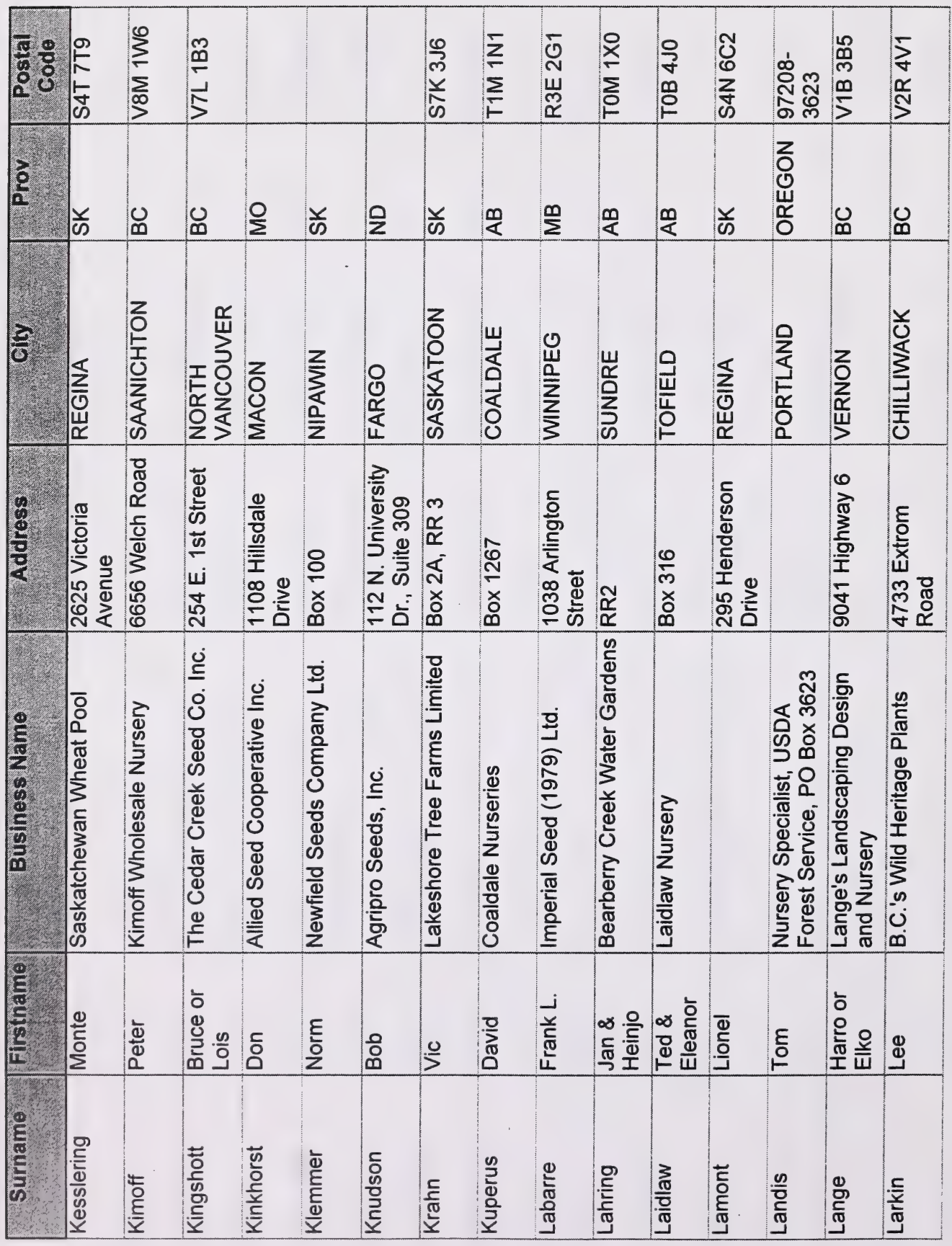




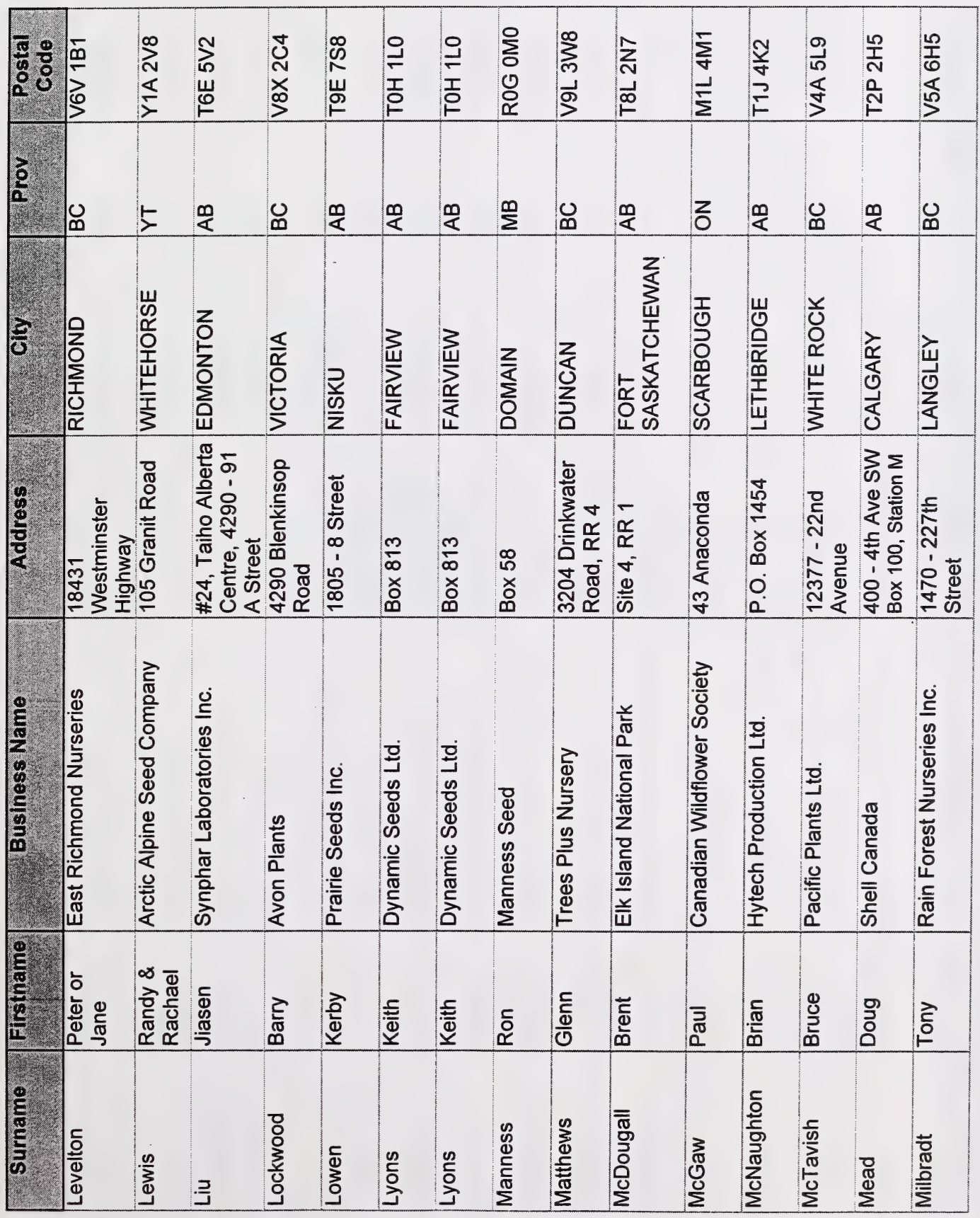




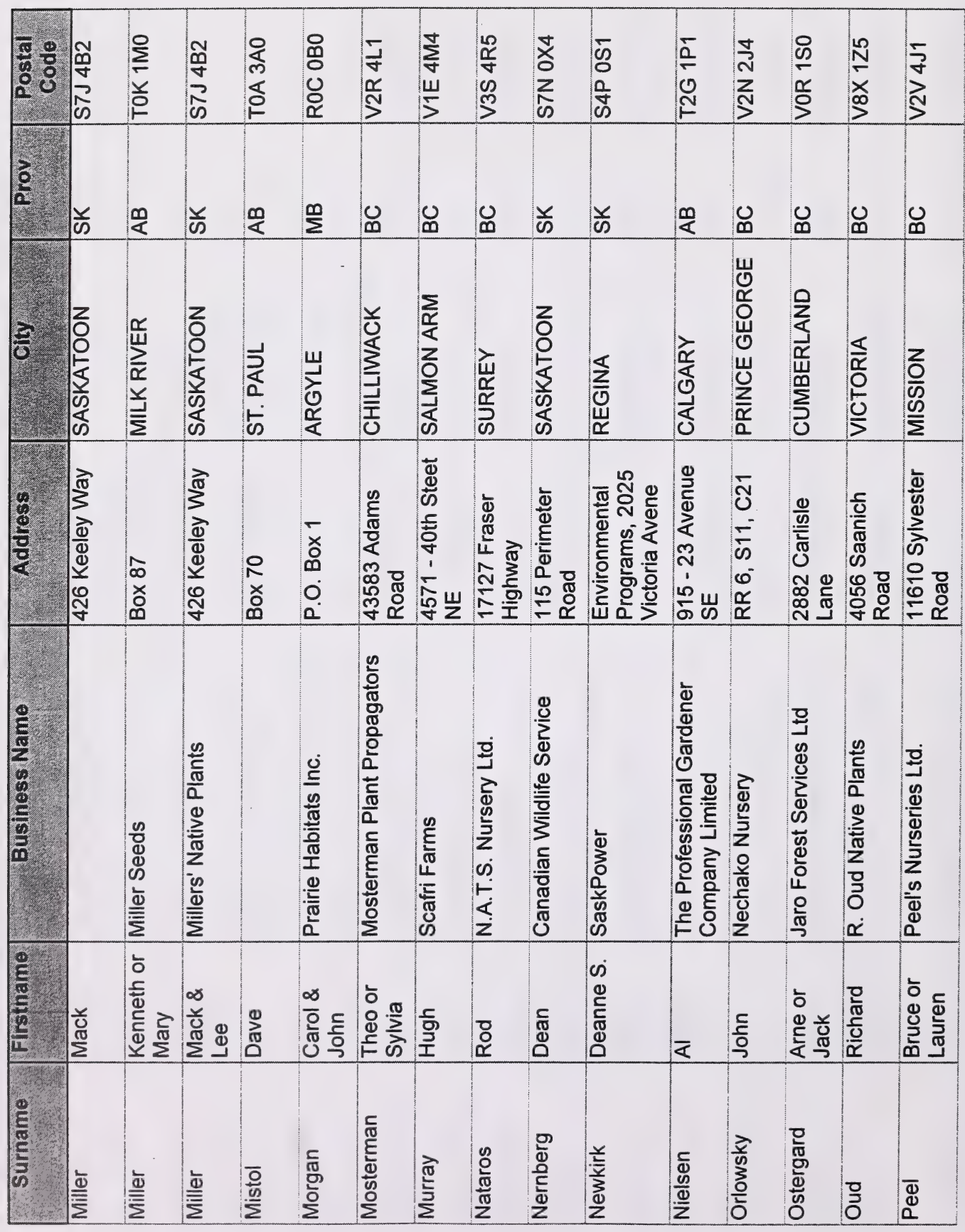




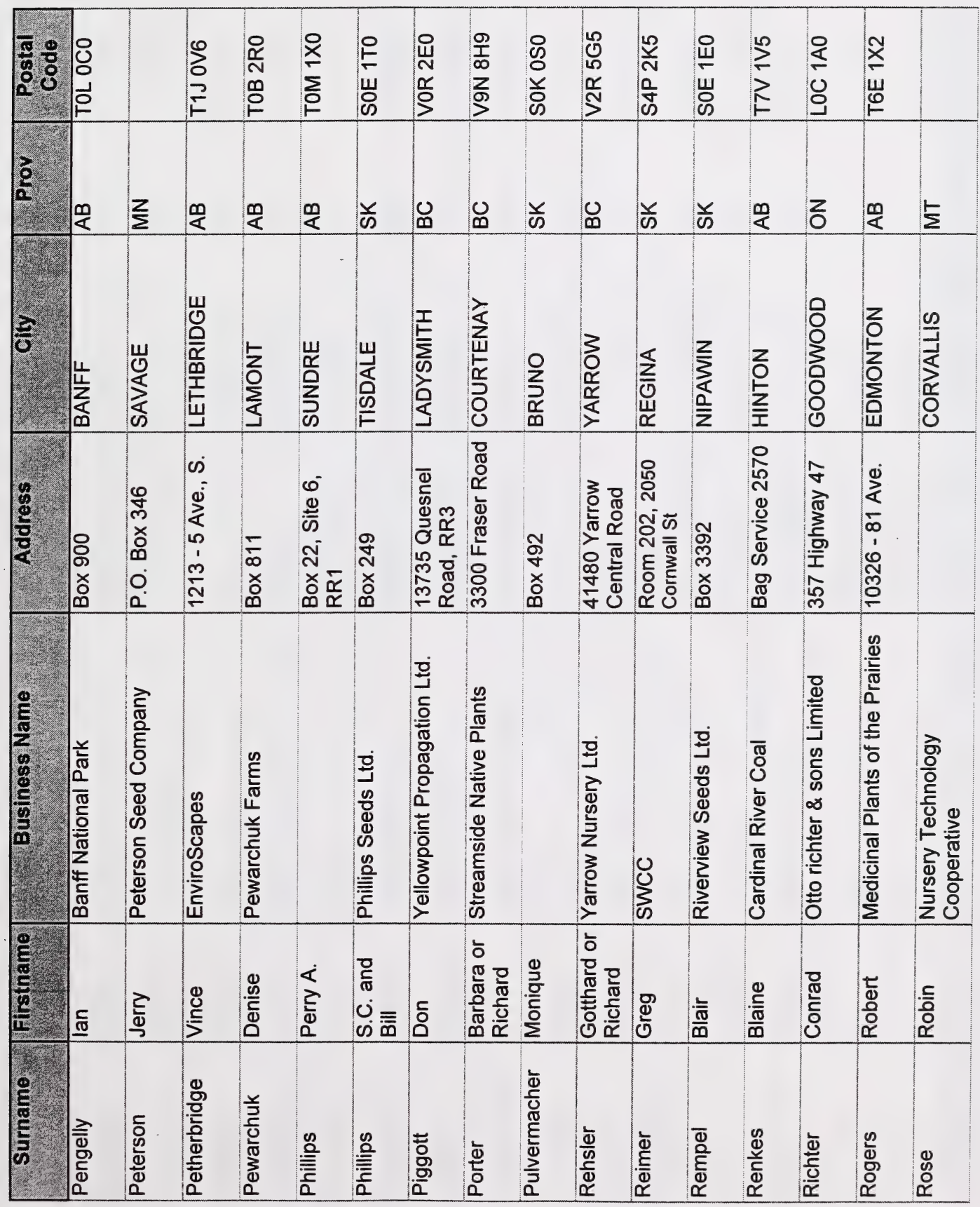




\begin{tabular}{|c|c|c|c|c|c|c|c|c|c|c|c|c|c|c|c|}
\hline 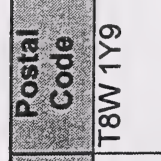 & 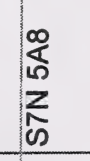 & 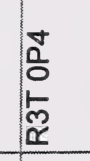 & $\begin{array}{l}8 \\
\text { N } \\
\text { I } \\
\end{array}$ & 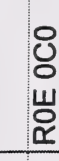 & & & 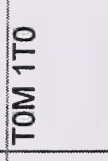 & $\begin{array}{l}0 \\
\frac{8}{2} \\
8 \\
0 \\
\end{array}$ & 0 & \begin{tabular}{l}
0 \\
0 \\
$u$ \\
$\ddot{\alpha}$ \\
\hdashline
\end{tabular} & 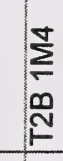 & $\begin{array}{l}\text { P } \\
\text { P } \\
\text { I } \\
\text { I } \\
\end{array}$ & $\begin{array}{l}8 \\
8 \\
0 \\
8\end{array}$ & $\begin{array}{l}\infty \\
R^{\infty} \\
\vdots \\
\vdots\end{array}$ & 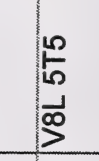 \\
\hline & के & $\sum^{\infty}$ & 迎 & $\sum^{\infty}$ & $\frac{m}{4}$ & & $\frac{\infty}{<}$ & $\bar{\varpi}$ & $\sum^{\infty}$ & $\stackrel{\infty}{\Sigma}$ & $\frac{\infty}{<}$ & $\stackrel{\infty}{<}$ & के & 迎 & U \\
\hline 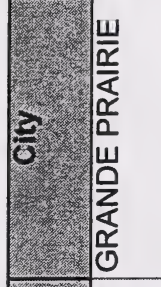 & 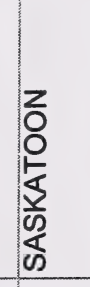 & 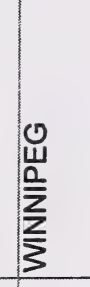 & 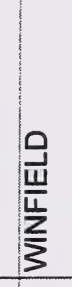 & 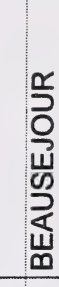 & $\begin{array}{l}0 \\
z \\
0 \\
k \\
1 \\
k \\
3 \\
3\end{array}$ & & 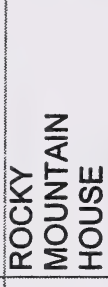 & 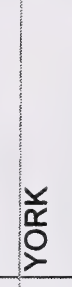 & 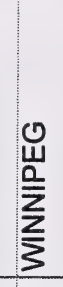 & 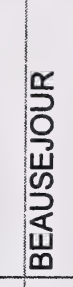 & 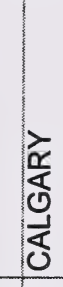 & 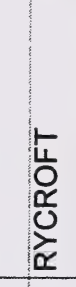 & & 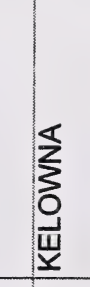 & $\frac{\bar{u}}{\frac{2}{\omega}}$ \\
\hline 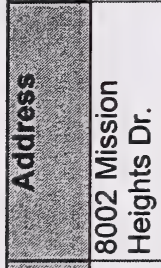 & 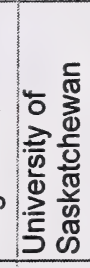 & 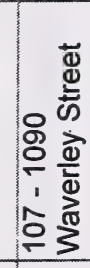 & & 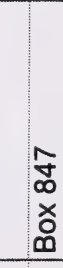 & 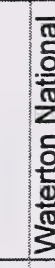 & & 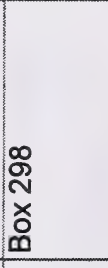 & 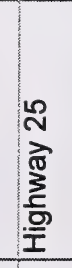 & 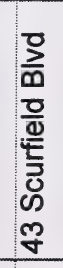 & 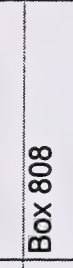 & 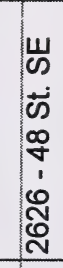 & $\begin{array}{l}\text { o } \\
x \\
\\
0\end{array}$ & $\begin{array}{l}\tilde{N} \\
\text { I. } \\
\text { I. }\end{array}$ & 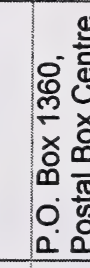 & 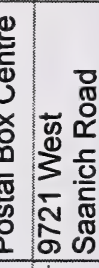 \\
\hline 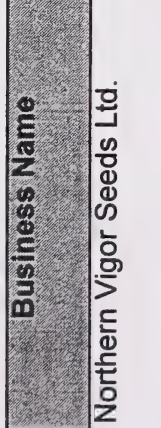 & 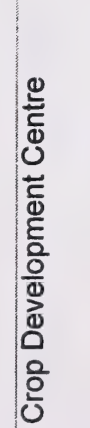 & 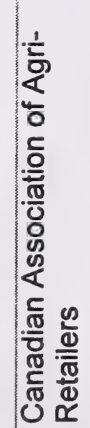 & 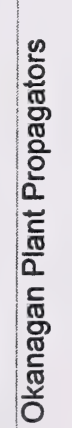 & 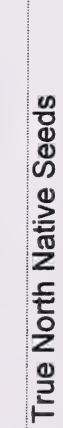 & 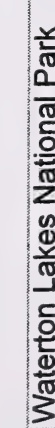 & & 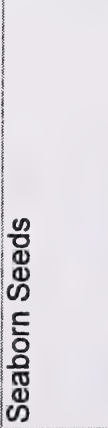 & 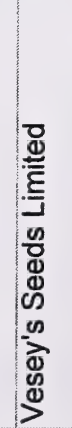 & 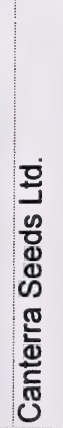 & 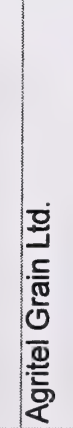 & 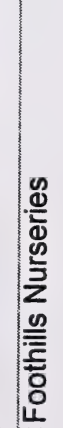 & 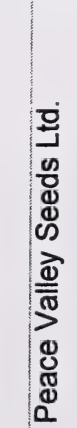 & & 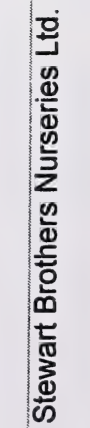 & 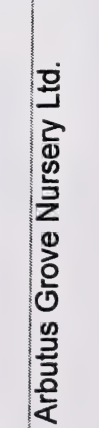 \\
\hline$\frac{0}{\frac{\sigma}{0}}$ & 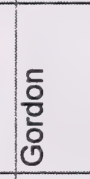 & 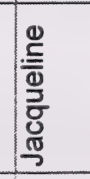 & & $\Xi$ & 하 & 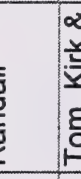 & 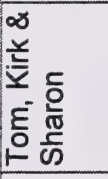 & $\infty$ & & 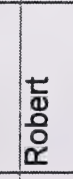 & 罯 & 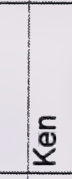 & 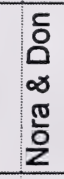 & ㄷ๊ & 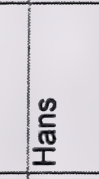 \\
\hline $\begin{array}{l}\frac{\pi}{\pi} \\
0 \\
0 \\
0\end{array}$ & 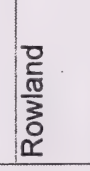 & 幽 & i) & 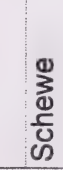 & 离 & & 总 & 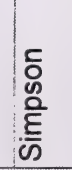 & & 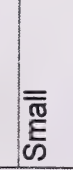 & (气) & 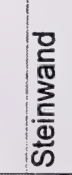 & $\exists$ & 党 & 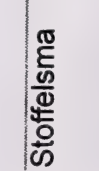 \\
\hline
\end{tabular}




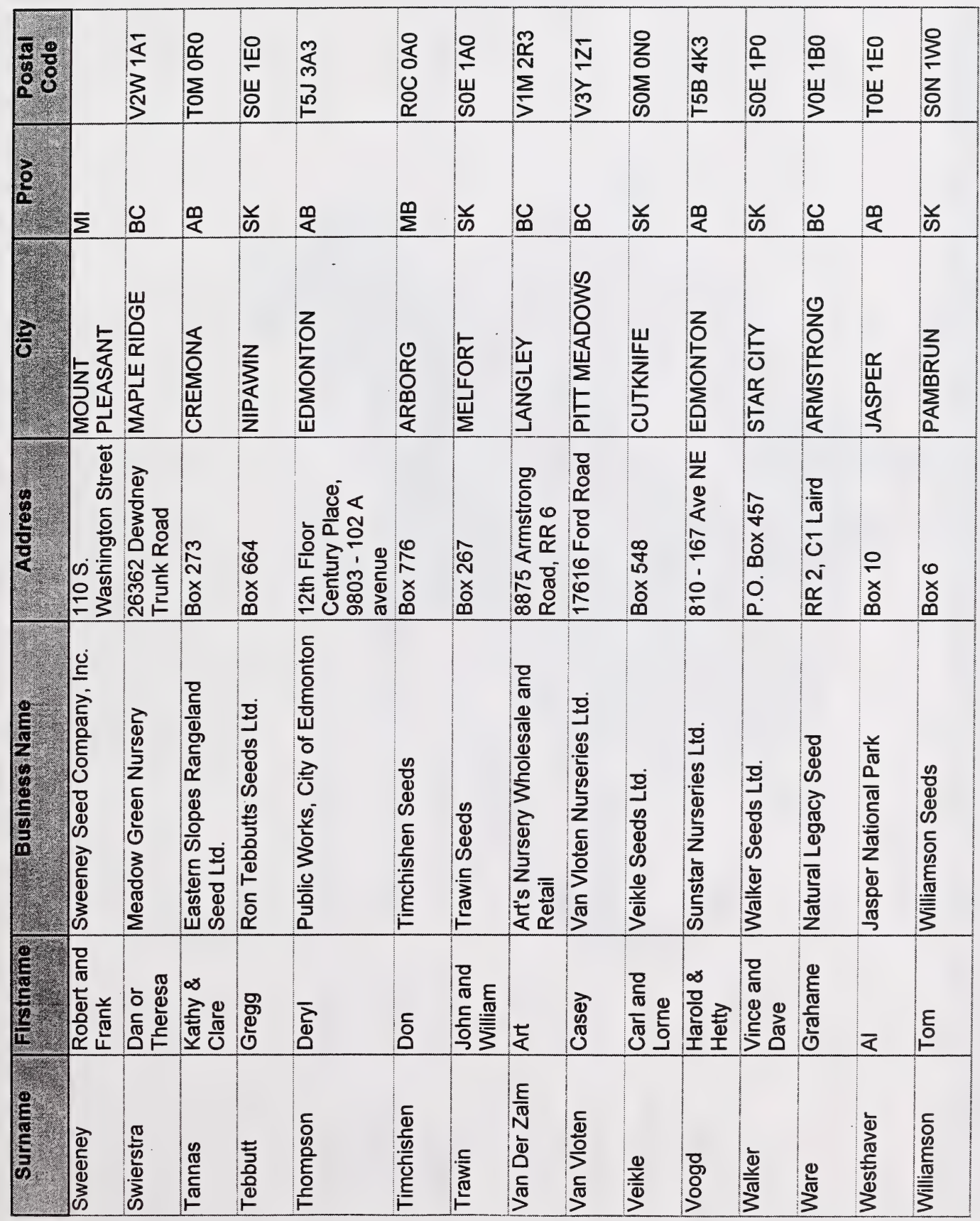




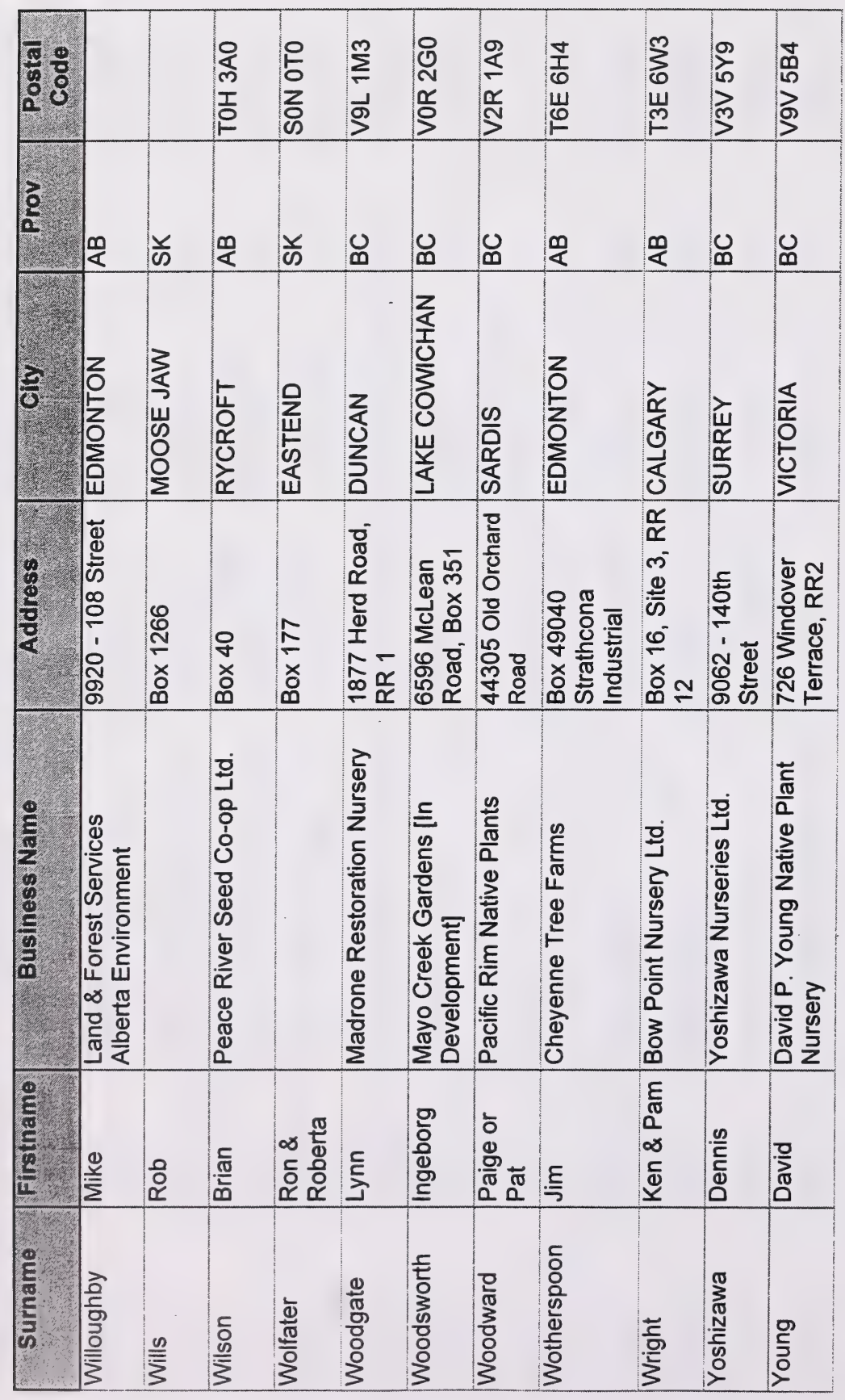




\section{APPENDIX 8}

\section{Ecological Regions of North America Level I}

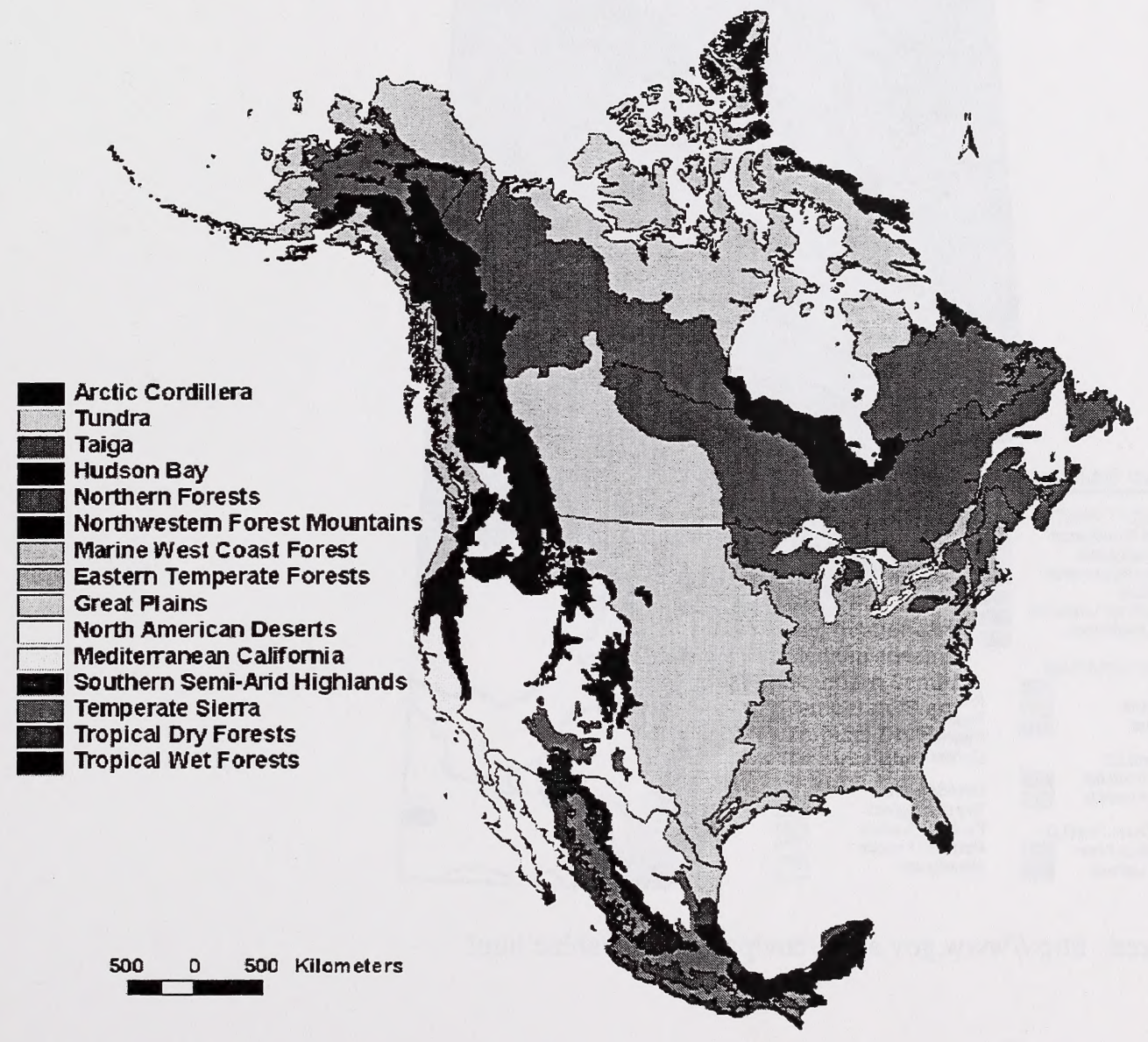

Source: http://www.cprc.uregiona.ca/ccea/ecozones/levell.html 


\section{APPENDIX 9}

Natural Regions of Alberta

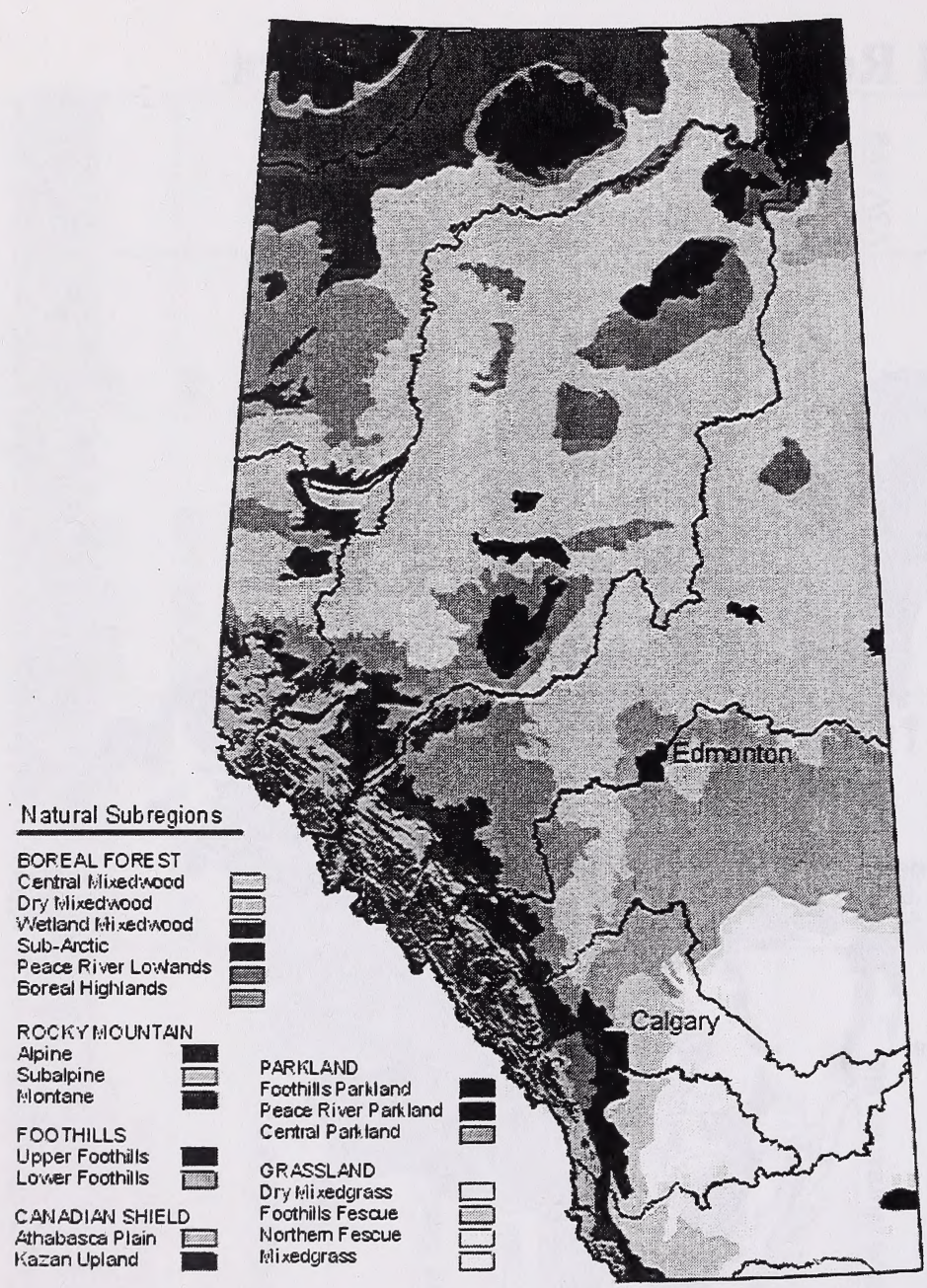

Source: http://www.gov.ab.ca/env/parks/anhic/abhic.html 

National Library of Canada

Bibliothèque nationale du Canada

||||||||||||||||||||||||||||||||||||||||||||||||||||||||||||||||||||||||||||||||||||||||||||||||||||||||||||||||||||||||||

33286521724167 